\title{
Shoot Cadmium Accumulation of Maize, Sunflower, Flax, and Spinach as Related to Root Physiology and Rhizosphere Effects
}

\author{
Dissertation \\ to obtain the Ph. D. degree \\ in the Faculty of Agricultural Sciences, \\ Georg-August-University Goettingen, Germany
}

Submittet by

Christos Stritsis

born in Goumenissa, Greece

Goettingen, December 2010 


\section{7}

1. Name of referee:

2. Name of co-referee:

Date of dissertation:
Prof. Dr. Norbert Claassen

Prof. Dr. Norbert Lamersdorf

$17^{\text {th }}$ of February 2011 


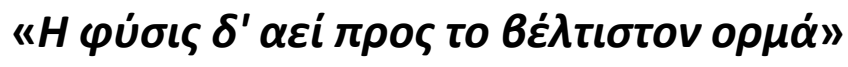

Theophrastus (371-286 BC), the causes of plants A.16.11

The father of Botany 


\section{CONTENTS}

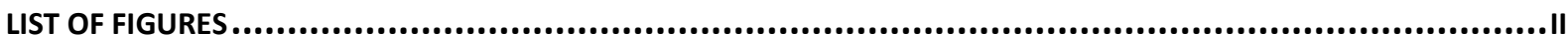

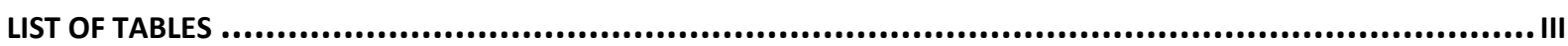

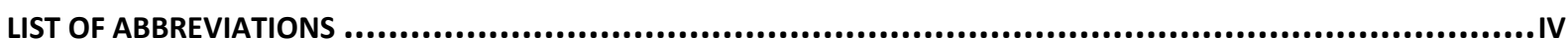

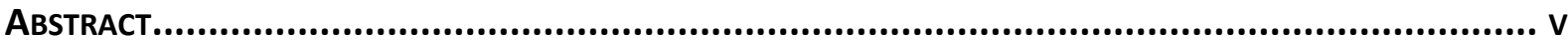

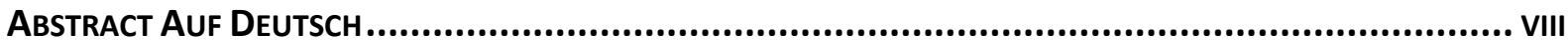

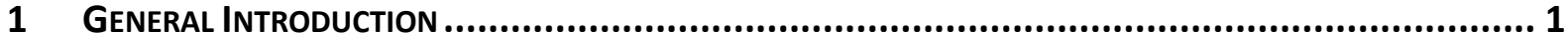

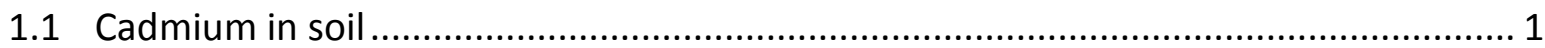

1.2 Shoot $\mathrm{Cd}$ accumulation and threshold level of damage ......................................... 3

1.3 Factors affecting the shoot $\mathrm{Cd}$ concentration of plants......................................... 8

1.4 Investigation of hypotheses in this research ..................................................... 11

2 Shoot Cadmium Concentration of Soll Grown Plants as Related to their Root Properties12

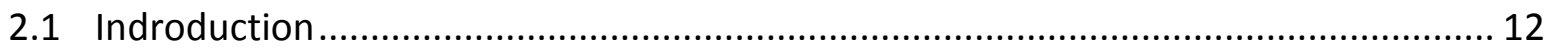

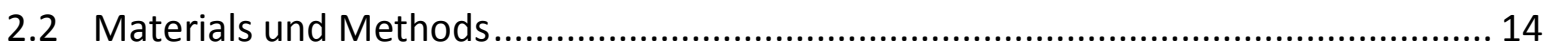

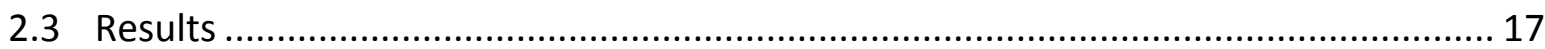

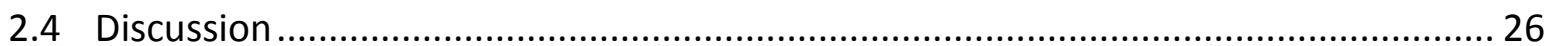

3 Mechanistic Simulation and Measured Cadmium Uptake from Soll .............................. 32

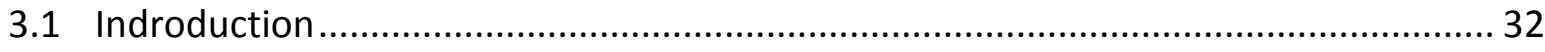

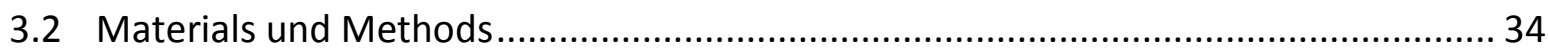

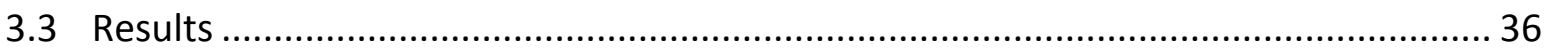

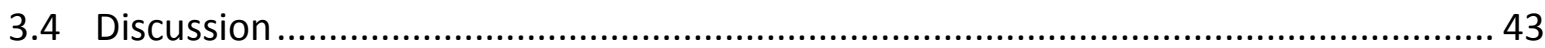

4 Cadmium Fractions in Soll as Affected by Plant Growth ......................................... 49

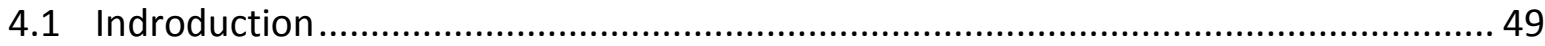

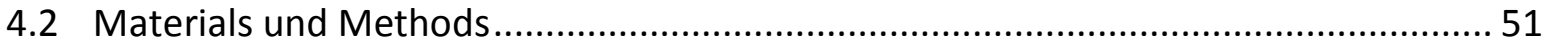

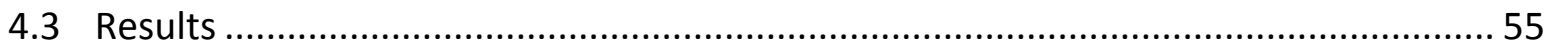

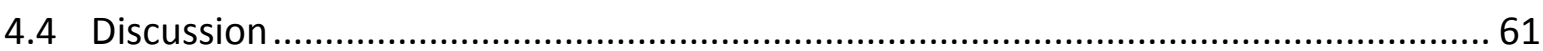

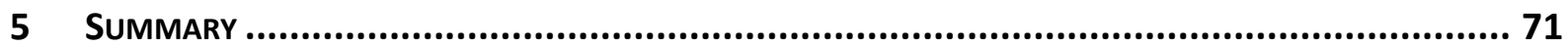

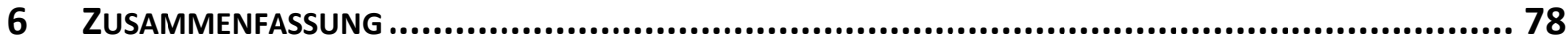

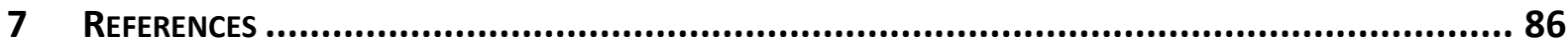

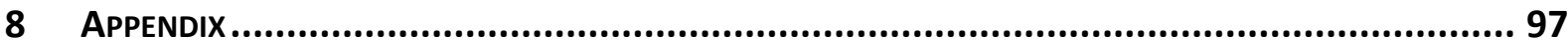

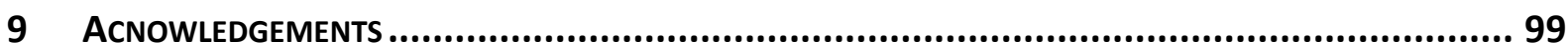

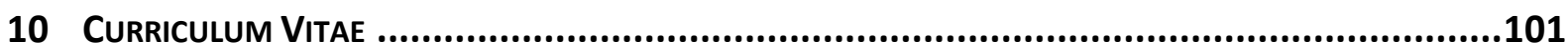




\section{LIST OF FIGURES}

Figure 2-1 Relative shoot dry weight of plants after $43 \mathrm{~d}$ growing at different $\mathrm{Cd}$ addition to the soil ( $100 \%$ were $7.1 \mathrm{~g} \mathrm{plant}^{-1}$ for maize, $3.4 \mathrm{~g}$ plant $^{-1}$ for sunflower, $2.2 \mathrm{~g} \mathrm{plant}^{-1}$ for flax and $4.1 \mathrm{~g}$ plant $^{-1}$ for spinach). Different upper case letters show significant differences among plants at the same $\mathrm{Cd}$ addition. Different lower case letters show significant differences of the same plant at different $\mathrm{Cd}$ additions ( $\mathrm{p} \leq 0.05$; Student-Newmann-Keuls method). .18

Figure 2-2 Shoot $\mathrm{Cd}$ influx at different $\mathrm{Cd}$ addition to the soil. Different upper case letters show significant differences among plants at the same $\mathrm{Cd}$ addition. Different lower case letters show significant differences of the same plant at different $\mathrm{Cd}$ additions ( $p \leq 0.05$; Student -NewmannKeuls method).

Figure 2-3 Cadmium in soil solution at different $\mathrm{Cd}$ addition to the soil (average between $1^{\text {st }}$ and $2^{\text {nd }}$ harvest). Different upper case letters show significant differences among plants at the same $\mathrm{Cd}$ addition. Different lower case letters show significant differences of the same plant at different $\mathrm{Cd}$ additions ( $\mathrm{p} \leq 0.05$; Student-Newmann-Keuls method).

Figure 2-4 Shoot $\mathrm{Cd}$ influx against average $\mathrm{Cd}$ concentration in soil solution between first and second harvest after $\mathrm{Cd}$ addition.

Figure 3-1 Sensitivity analysis. Response of calculated influx to changes in the initial soil solution concentration $\left(\mathrm{C}_{\mathrm{Li}}\right)$. Initial data set of the treatment with an application of $14 \mu \mathrm{mol} \mathrm{Cd}$ $\mathrm{kg}^{-1}$. M: maize, S: sunflower, F: flax, Sp: spinach. Circle with letter indicates at which change ration calculated influx is equal to measured influx

Figure 3-2 Calculated depletion of $\mathrm{Cd}$ from the rhizosphere of maize after 14 days of uptake at $14 \mu \mathrm{mol} \mathrm{Cd} \mathrm{kg}{ }^{-1}$ used NST 3.0 (A). Effect of changing $C_{\mathrm{Li}}$ or $\alpha$ value on calculated $C d$ depletion in the rhizosphere of maize $(B \& C)$.

Figure 3-3 Calculated depletion of $\mathrm{Cd}$ from the rhizosphere of spinach after 14 days of uptake at $14 \mu \mathrm{mol} \mathrm{Cd} \mathrm{kg}{ }^{-1}$ used NST 3.0 (A). Effect of changing $C_{\mathrm{Li}}$ or $\alpha$ value on calculated Cd depletion in the rhizosphere of spinach $(B \& C)$.

Figure 4-1 Cadmium in the first four fractions by comparison at $40 \mu \mathrm{mol} \mathrm{Cd} \mathrm{kg}{ }^{-1}$ addition in soil. Different upper case letters show significant differences among plant and fractions $\npreceq 0.01$; Student-Newmann-Keuls method). .56

Figure 4-2 Percentage distribution of $\mathrm{Cd}$ in the run of the experiment on the 7 fractions of sequential extraction in soil after $40 \mu \mathrm{mol} \mathrm{kg}{ }^{-1} \mathrm{Cd}$ addition. 
Figure 4-3 Comparison of $\mathrm{Cd}$ uptake by different plants species with the change $(\Delta)$ of $C d$ in soil Cd fractions I, II, III, IV caused by plant growth.

Figure 4-4 Relationship between $\mathrm{Cd}$ concentration in soil solution, $\mathrm{C}_{\mathrm{Li}}$, at second harvest and $\mathrm{Cd}$ contents in Cd fractions I, II, III, IV

Figure 4-5 Relationship between the Cd content in Cd fractions I, II, III, IV and the varying concentration, $\mathrm{C}_{\mathrm{L}}$, of $\mathrm{Cd}$ in the soil solution (average between first and second harvest) getting from sensitivity analysis. $\mathrm{C}_{\mathrm{Li}}$ is the $\mathrm{Cd}$ concentration in solution at which calculated and measured $\mathrm{Cd}$ influx was equal. .60 


\section{LIST OF TABLES}

Table 2-1 Root and shoot Cd concentration and content after $28 \mathrm{~d}$ and $43 \mathrm{~d}$ of growth at different $\mathrm{Cd}$ addition to the soil. Translocation to shoot $(\mathrm{p})$ is shoot $\mathrm{Cd}$ content expressed as \% of total plant $\mathrm{Cd}$. Different upper case letters show significant differences among plants at the same $\mathrm{Cd}$ addition. Different lower case letters show significant differences of the same plant at different $\mathrm{Cd}$ additions ( $\mathrm{p} \leq$ 0.05; Student-Newmann-Keuls method, $n$. d.: not determined)......19

Table 2-2 Root length density $\left(R L_{V}\right)$, root radius $\left(r_{0}\right)$ and half distance between neighboring roots $\left(r_{1}\right)$ at different $\mathrm{Cd}$ addition to the soil at second harvest (43d after germination). Different upper case letters show significant differences among plants at the same $\mathrm{Cd}$ addition. Different lower case letters show significant differences of the same plant at different $\mathrm{Cd}$ additions $(p \leq$ 0.05; Student-Newmann-Keuls method).

Table 2-3 Plant factors determining the shoot Cd concentration; root area / shoot dry weight ratio (RA / SDW), shoot growth rate $\left(R G R_{S}\right)$ and shoot influx at different $C d$ addition to the soil after $43 \mathrm{~d}$ of growth. Different upper case letters show significant differences among plants at the same $\mathrm{Cd}$ addition. Different lower case letters show significant differences of the same plant at different $\mathrm{Cd}$ additions ( $\mathrm{p} \leq 0.05$; Student-Newmann-Keuls method).

Table 3-1 Parameters used for Cd-uptake model calculations. .37

Table 3-2 Calculated shoot influx in comparison to measured shoot influx of maize, sunflower, flax and spinach at different $\mathrm{Cd}$ addition to the soil. .38

Table 3-3 The values are the factors (change factor) by which the original $\mathrm{Cd}$ soil solution concentration, $\mathrm{C}_{\mathrm{L} \text {, }}$, or the root absorbing power, $\alpha$, had to be changed so that the calculated influx became equal to the measured $\mathrm{Cd}$ influx. .40

Table 8-1 The sequential extraction scheme for $\mathrm{Cd}$ fractionation after Zeien and Brümmer (1989)

Table 8-2 Partitioning of $\mathrm{Cd}$ in sandy soil ( $\mathrm{pHCaCl} 24.5,2.8 \% \mathrm{C}, 5 \%$ clay) among the seven fractions of the sequential extraction of Zeien and Brümmer (1989) after addition of $40 \mu \mathrm{mol} C d$ $\mathrm{kg}^{-1}$ soil.

Table 8-3 Soil solution Cd concentrations at first and second harvest obtained from modified displacement method according to Adams (1974) 


\section{LIST OF ABBREVIATIONS}

$\mathrm{C}_{\mathrm{LO}}$

$\mathrm{C}_{\mathrm{Li}}$

FAAS

GFAAS

$\mathrm{I}_{\mathrm{n}}$

NST 3.0

$p$

PAR

$r_{0}$

RA

RA / SDW

$\mathrm{RGR}_{\mathrm{S}}$

$r_{1}$

$\mathrm{RL}_{\mathrm{V}}$

RSDW

SDW

$\mathrm{t}$

U

$\mathrm{X}$

$\alpha$

$D_{L}$

$\Theta$

f
Concentration at the root surface

Initial soil solution concentration

Flame atomic absorption spectroscopy

Graphite furnace atomic absorption spectrometer

Net influx mol cm $\mathrm{cm}^{-1}$

Mechanistic model of nutrient uptake form soil by plants

Proportion of $\mathrm{Cd}$ translocated from the root to the shoot in $\%$

Photosynthetically active radiation in $\mathrm{mol} \mathrm{m}^{-2} \mathrm{~s}^{-1}$

Root radius in $\mathrm{cm}$

Root-surface area per plant in $\mathrm{cm}^{2}$

Root area / shoot dry weight ratio in $\mathrm{cm}^{2} \mathrm{~g}^{-1}$

Relative growth rate of the shoot in $\mathrm{s}^{-1}$ or $\mathrm{d}^{-1}$

Half distance between neighbouring roots in $\mathrm{cm}$

Root length density in $\mathrm{cm} \mathrm{cm}^{-3}$

Relativ shoot dry weigth in \%

Shoot dry weight in g

Time

Shoot Cd content in mol plant ${ }^{-1}$

Shoot $\mathrm{Cd}$ concentration in $\mathrm{mg} \mathrm{kg}^{-1}$ or $\mathrm{mol} \mathrm{g}^{-1}$

Root absorbing power in $\mathrm{cm} \mathrm{s}^{-1}$

Diffusion coefficient in water in $\mathrm{cm}^{2} \mathrm{~s}^{-1}$

Volumetric soil water content in $\mathrm{cm}^{3} \mathrm{~cm}^{-3}$

Impedance factor 


\section{ABSTRACT}

Plants differ widely in $\mathrm{Cd}$ accumulation when grown on $\mathrm{Cd}$ contaminated soils. This is because several soil properties interact with several plant properties. Plant factors determining the shoot $\mathrm{Cd}$ concentration of plants are the root-shoot ratio [surface area (RA) per unit of shoot dry weight (SDW)], the relative shoot growth rate $\left(R_{G} R_{S}\right)$, the $\mathrm{Cd}$ total net influx $\left(\mathrm{I}_{\mathrm{nt}}\right)$ and the proportion of absorbed $\mathrm{Cd}$ that is translocated from the root to the shoot (p). And the Cd influx is furthermore influenced by plant properties like the $\mathrm{Cd}$ uptake kinetics and the ability of the root to affect the $\mathrm{Cd}$ solubility in the rhizosphere.

The aim of this research was to assess the significance of the above mentioned plant properties for the shoot $\mathrm{Cd}$ accumulation for different plant species. A growth chamber experiment was carried out with maize, sunflower, flax, and spinach

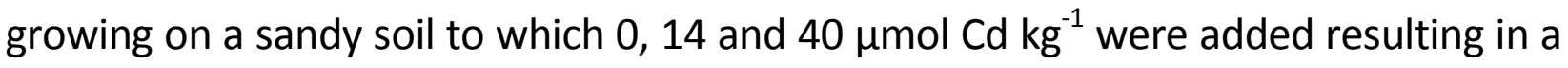
$\mathrm{Cd}$ soil solution concentration of $0.04,0.68$ and $2.51 \mu \mathrm{mol} \mathrm{L}^{-1}$. At the high $\mathrm{Cd}$ addition $\left(40 \mu \mathrm{mol} \mathrm{kg}{ }^{-1}\right)$ SDW of flax and spinach was significantly decreased by $20 \%$ and $40 \%$, respectively while maize and sunflower showed no yield depression. The shoot Cd concentration of plants increased in all species linearly with the $\mathrm{Cd}$ addition to the soil. The $\mathrm{Cd}$ concentration in shoots varied between maize and spinach by a factor of about 30, sunflower and flax were in between. The root-shoot ratio (RA/SDW) varied by a factor of two and the $R G R_{S}$ by a factor of 1.5 . The main factor related to different $\mathrm{Cd}$ concentrations in shoots was the $\mathrm{Cd}$ shoot influx which varied between maize and spinach by a factor of almost 40 at low and by a factor of 26 at high Cd addition. Differences in $\mathrm{Cd}$ influx among species may be based on their ability to solubilize $\mathrm{Cd}$ in soil or on differences in Cd uptake kinetics. 
Plants had a strong effect on $\mathrm{Cd}$ concentration in soil solution, $\mathrm{C}_{\mathrm{L} \text {, }}$ i.e. plant growth decreased (maize, sunflower) as well as increased (flax, spinach) $\mathrm{C}_{\mathrm{Li}}$. The decrease of $\mathrm{C}_{\mathrm{Li}}$ at low $\mathrm{Cd}$ addition was not related to $\mathrm{Cd}$ uptake by the plants, since maize with the lowest $\mathrm{Cd}$ uptake showed the strongest decrease of $\mathrm{C}_{\mathrm{Li}}$ (about 65\%), whereas spinach with the highest $C d$ uptake, showed the least decrease of $C_{L i}$ (about 20\%) indicating a $\mathrm{Cd}$ immobilization in soil caused from root activity of maize or spinach. In contrast to decreasing, $\mathrm{C}_{\mathrm{Li}}$ was increased by flax at both $\mathrm{Cd}$ levels up to $100 \%$ and by spinach by $23 \%$ at the high $\mathrm{Cd}$ addition to the soil. Plants therefore solubilized more $\mathrm{Cd}$ as was taken up by them. However, these effects did not totally explain the observed differences in their $\mathrm{Cd}$ influx. Further explanations were sought by using mechanistic modeling to simulate $\mathrm{Cd}$ uptake from soil. Modeling allowed including not only the effect plants had on $\mathrm{C}_{\mathrm{Li}}$ but also their different $\mathrm{Cd}$ uptake kinetics. Uptake kinetics was described by the root absorbing power, $\alpha$, which is the slope of the uptake isotherm, which is almost constant in the low concentration range as found in the soils of this experiment.

The simulated $\mathrm{Cd}$ influx was always higher than the measured one and for maize and flax it was about 10 times higher. The sensitivity analysis showed that the $\mathrm{Cd}$ soil solution concentration, $\mathrm{C}_{\mathrm{Li}}$, should be reduced by $90 \%$ for maize and by $37 \%$ for spinach in order for the simulated $\mathrm{Cd}$ influx to become the same as the measured one. The changes of the $\alpha$ value lead to similar results.

The sequential $\mathrm{Cd}$ fractionation in the soil with and without plants demonstrated that plants affect the $\mathrm{Cd}$ binding in soil. For spinach and sunflower $70 \%$ of $\mathrm{Cd}$ was found in the mobile and easily mobilizable fraction while for flax it was only $55 \%$. In Mn oxides occluded Cd decreased in spinach and sunflower between $5-10 \%$ and in organically bound $\mathrm{Cd}$ increased in maize and flax about $5 \%$. The other fractions contained only 
$5 \%$ of the total cadmium that was bound to solid phase. However, the effect different plants had on Cd binding in soil was not related to the effect they had had on Cd concentration in the soil solution. 


\section{ABSTRACT AUf DEUTSCH}

Pflanzen unterscheiden sich in der Cd-Aufnahme und -Akkumulation, wenn sie auf mit Cd kontaminierten Böden wachsen. Dies ist darin begründet, dass mehrere Pflanzeneigenschaften mit mehreren Bodeneigenschaften interagieren. Der CdGehalt im Spross $\left(X_{S}\right)$ hängt ab von: a) der Größe des Wurzelsystems, charakterisiert durch das Wurzel-Spross-Verhältnis, WSV (RA/W, Wurzeloberfläche zu Sprossgewicht, b) der relativen Wachstumsrate des Sprosses $\left.\left(R G R_{S}\right), c\right)$ dem Netto-Influx $\left(I_{n t},\right)$ und d) dem Anteil des aufgenommenen Cd, der in den Spross verlagert wird $(p)$. Der Cd-Influx hängt u.a. ab von der Cd-Aufnahmekinetik und der Mobilisierung des Cd im Boden durch die Wurzel.

Ziel dieser Arbeit war es, die Bedeutung der oben genannten Pflanzeneigenschaften für die Cd-Akkumulation im Spross verschiedener Pflanzenarten zu untersuchen. Hierfür wurde Mais, Sonnenblume, Öllein, und Spinat auf einem sandigen Boden ( $\mathrm{pHCaCl}_{2} 4,5,2,8 \% \mathrm{C}, 5 \%$ Ton) mit drei Cd-Stufen $\left(0,14\right.$ und $40 \mu \mathrm{mol} \mathrm{kg}{ }^{-1}$ Boden, was in einer Cd-Konzentration in der Bodenlösung von $0,04,0,68$ und $2,51 \mu \mathrm{mol} \mathrm{L}^{-1}$ resultierte) angezogen. Bei der hohen Cd Zufuhr $\left(40 \mu \mathrm{mol} \mathrm{kg}^{-1}\right)$, wurde die Trockenmasse, TM, von Öllein und Spinat signifikant um 20\% bzw. 40\% reduziert während Mais und Sonnenblume keine TM-Depression zeigten. Der Cd-Gehalt im Spross erhöhte sich in allen Pflanzenarten linear mit steigender Cd-Zufuhr zum Boden. Er variierte zwischen Mais und Spinat um den Faktor 30, Die Cd-Gehalte von Sonnenblume und Öllein lagen dazwischen. Das WSV variierte um den Faktor 2 bis 3, wobei Spinat den niedrigsten Wert hatte und die $R G R_{S}$ variierte um maximal 1,7. Die Variation in dem WSV und der $R G R_{S}$ konnten die Unterschiede im Cd-Gehalt der Pflanzenarten nicht erklären. Es war 
vor allem der Cd-Sprossinflux, der zwischen Mais und Spinat bis um den Faktor 40 variierte, der die unterschiedlichen Cd-Gehalte im Spross bestimmte. Der unterschiedliche $\mathrm{Cd}$-Influx könnte darin begründet sein, dass Pflanzen $\mathrm{Cd}$ im Boden unterschiedlich stark lösen bzw. mobilisieren oder eine unterschiedliche Cd-Aufnahmekinetik besitzen. Pflanzen hatten einen starken Einfluss auf die Cd-Konzentration in der Bodenlösung, $\mathrm{C}_{\mathrm{Li}}$. Mais und Sonnenblumen erniedrigten Spinat und Öllein erhöhten sie. Die Abnahme von $\mathrm{C}_{\mathrm{Li}}$ bei niedriger $\mathrm{Cd}$-Zufuhr war nicht in der Cd-Aufnahme durch die Pflanzen begründet, da Mais mit der niedrigsten Cd-Aufnahme die stärkste (ca. 65\%), dagegen Spinat mit der höchsten Cd-Aufnahme die geringste Abnahme von $\mathrm{C}_{\mathrm{Li}}$ (ca. 20\%) zeigte. Dies deutet auf eine Cd-Immobilisierung im Boden durch Mais bzw. Spinat hin. Im Gegensatz zur Abnahme, wurde $C_{\mathrm{Li}}$ durch Öllein bei beiden $\mathrm{Cd}$-Zugaben um bis zu $100 \%$ und von Spinat um 23\% bei der hohen Cd-Zufuhr zum Boden erhöht. Pflanzen mobilisierten daher mehr $\mathrm{Cd}$ als sie aufnahmen. Diese Effekte konnten die beobachteten Unterschiede im Cd-Influx jedoch nicht vollständig erklären. Mit Hilfe einer mechanistischen Modellierung der Cd-Aufnahme aus dem Boden wurde neben der Wirkung der Pflanzen auf $\mathrm{C}_{\mathrm{Li}}$ auch deren Aufnahmekinetik berücksichtigt. Die Aufnahmekinetik wurde mit der Wurzel-Aufnahmefähigkeit (root absorbing power), $\alpha$, beschrieben, welche das Steigungsmaß der Aufnahme-Isotherme ist, die, im niedrigen Konzentrationsbereich, nahezu konstant ist. Der mit dem Modell berechnete Cd-Sprossinflux war stets höher als der gemessene, bei Mais und Öllein sogar um den Faktor 10. Die Sensitivitätsanalyse zeigte, dass $C_{\mathrm{Li}}$, um $90 \%$ bei Mais und um $37 \%$ bei Spinat verringert werden müsste, um eine Übereinstimmung des gemessenen mit dem berechneten Cd-Sprossinflux zu erreichen. Die Veränderung von $\alpha$-Werten führte zu ähnlichen Ergebnissen. 
Die sequentielle Fraktionierung von $\mathrm{Cd}$ im Boden mit und ohne Pflanzen zeigte, dass die Pflanzen die Cd-Bindung im Boden beeinflussten. Bei Spinat und Sonnenblume wurden $70 \%$ des $\mathrm{Cd}$ in der mobilen und leicht mobilisierbaren Fraktion gefunden, während es bei Öllein nur 55\% waren. Die in Mn-Oxiden okkludierte Fraktion verringerte sich bei Spinat und Sonnenblume zwischen 5-10\% und die organisch gebundene Fraktion stiegt bei Mais und Öllein um etwa 5\% an. Die restlichen Fraktionen enthielten nur 5\% des gesamten $\mathrm{Cd}$ des Bodens. Die Wirkung der Pflanzen auf die Cd-Bindung im Boden stand jedoch in keiner Beziehung zu deren Wirkung auf die Cd-Konzentration in der Bodenlösung. 


\section{GENERAL INTRODUCTION}

The uptake of nutrients from the soil is a complex process and depends on plant characteristics, soil properties and element properties. Therefore, many scientists have researched the basics of nutrient transport in the soil (mass flow, diffusion), nutrient dynamics in the rhizosphere (depletion, accumulation), and the uptake kinetics (Barber, 1962; Jungk and Claassen 1997; Buhse, 1992, Steingrobe, 1992, Meyer, 1993; Trehan und Claassen, 2000, 2001 und 2004; Bhadoria et al., 2004).

This study will focus on the non-essential and toxic heavy metal Cadmium (Cd). Cadmium is the $64^{\text {th }}$ most abundant elements in the Earth' crust (Sarkar, 2002), and the plants grown on $\mathrm{Cd}$-contaminated soils may absorb $\mathrm{Cd}$ in excessive quantities, which in turn, may cause clinical problems both to animals and to humans. It is therefore important to know the causes that lead to enrichment of Cd in plants.

\subsection{Cadmium in soil}

It enters the environment through industrial and metallurgical processes but mainly through the application of Cd-containing sewage sludge or by the application of phosphate fertilizers, which are distributed on land (Jackson and Alloway, 1991; di Toppi and Gabbrielli, 1999). Long-term applications of lands with sewage wastes containing heavy metals have been reported to affect adversely soils, plants and watercourses (Sikka et al., 2009). The high persistence of $\mathrm{Cd}$ in agricultural soils even after many years of application makes it a matter of concern because it is taken up by plants and through the food chain it reaches to humans and animals (Azad et al., 1986; Hooda et al., 1997; Yang et al. 2004). The 
geological presence of $\mathrm{Cd}$ in agricultural soils is only in very small quantities (0.1 $\mathrm{mg} \mathrm{kg}^{-1}$ ). The Cd content of uncontaminated soils in Germany is between 0.1 - 0.6 $\mathrm{mg} \mathrm{kg}^{-1}$ soil, while contaminated soils show greatly increased Cd levels from 3 up to $200 \mathrm{mg} \mathrm{kg}^{-1}$ (Scheffer / Schachtschabel, 2002, p.378).

The transfer of heavy metals such as $\mathrm{Cd}$ from soil to plants depends on soil, plant, and metal properties. Some factors that have been suggested to contribute to differential $\mathrm{Cd}$ accumulation include: high $\mathrm{Cd}$ soil concentration; high mobilization or immobilization of $\mathrm{Cd}$ in the rhizosphere by root exudates; high translocation of Cd from root to the shoots; evolving tolerance mechanism (Herms and Brümmer, 1980; Harter, 1983; Bergmann, 1993, pp355 - 361; Marschner, 1995, pp537 - 595; Eriksson and Söderström, 1996, Marschner und Römheld, 1996). Cadmium is dissolved in the soil solution and bound to the solid phase. In the solid phase, $\mathrm{Cd}$ is present as exchangeable ion or bound on the soil substance, such as Fe and $\mathrm{Mn}$ oxides or organic matter. A sequential fractionation is used to characterize the different binding forms of Cd in soil (Tessier et al., 1979; Gerth et al., 1981; Mahler et al., 1982; Brümmer and Herms, 1983; Zeien and Brümmer, 1989; Zeien 1995). In the soil solution, Cadmium is present as $\mathrm{Cd}^{2+}$ ion, or as inorganic or organic complex (Nolan et al., 2003). The solid-solution equilibrium determines the effective $\mathrm{Cd}^{2+}$ concentration and this in turn the extent of complex formation with organic and inorganic ligands in the soil solution. At low $\mathrm{pH}$ values $\mathrm{Cd}$ is found as $\mathrm{CdSO}_{4}{ }^{0}$ or $\mathrm{CdCl}^{+}$and in the alkaline range as $\mathrm{CdHCO}_{3}{ }^{+}$, or $\mathrm{CdCO}_{3}{ }^{0} \mathrm{CdSO}_{4}{ }^{0}$ (Sponito, 1989, p69; Gerke, 1995; Helmke, 1999). The organic Cd complexes in soil solution are less characterized, because the organic ligands can be very diverse, and could come from both the soil organic matter and from root exudates. The $\mathrm{Cd}$ availability has a high importance for its uptake and the root effect on the $\mathrm{Cd}$ 
solubility in soil can affect the Cd availability causing an increase or decrease of the $\mathrm{Cd}$ activity in the rhizosphere (i.e. the effective $\mathrm{Cd}$ concentration). Mench und Martin (1991) reported that the root exudates of Zea mays could not increase the $\mathrm{Cd}$ concentration in soil in comparison to root exudates of Nicotiana spp. due to the lower metal-binding ability of Zea mays exudates. The mobilization of $\mathrm{Cd}$ by Nicotiana spp. root exudates caused a linear increase of $\mathrm{Cd}$ concentration in the plant. Humic acid in soil can form complexes with $\mathrm{Cd}$ and therefore lower $\mathrm{Cd}$ uptake (Cabrera et al. 1988). On the other hand, organic acids such as citrate seem to be less effective and the presence of $\mathrm{Cd}$-citrates in the solution does not increase shoot Cd accumulation (Senden et al., 1995; Egle, 2002). A negative effect on the $\mathrm{Cd}$ availability for example, could be the formation of complexes with phytochelatin. It is known that plants exposed to $\mathrm{Cd}$ respond with an increased production of phytochelatin in the cell, which can bind and detoxify Cd (Sanità di Toppi und Gabrielli, 1999; Keltjens und Beusichem, 1998; Wojcik und Tukiendorf, 2005; Guo und Marschner, 1995). Whether phytochelatins or similar Cd complexing agents are exuded by roots and influence the $\mathrm{Cd}$ activity in the rhizosphere is poorly understood and further investigations are required to explain differences in profile of root exudates among plant species to explain the effect on Cd solubility. Therefore, in this study we aim to examine the effect of plants on Cd solubility in the rhizosphere.

\subsection{Shoot Cd accumulation and threshold level of damage}

Cadmium toxicity in plants has been reported worldwide, which often limits plant growth and results in decreased yield. The toxicity depression occurred at different soil $\mathrm{Cd}$ concentration. Cadmium-sensitive plants such as spinach, soybean, and lettuce grew at loamy soil $(\mathrm{pH} \mathrm{7.5)}$ pre-treated with a municipal 
sewage sludge were injured by soil Cd levels of $35.5-115.5 \mu \mathrm{mol} \mathrm{Cd} \mathrm{kg}{ }^{-1}$; whereas, tomato and cabbage tolerated soil levels of approximately $1.5 \mathrm{mmol} \mathrm{Cd} \mathrm{kg}$ soil without exhibiting injury symptoms. Rice was tolerant at $5.6 \mathrm{mmol} \mathrm{Cd} \mathrm{kg}^{-1}$ soil (Bingham et al., 1975). Keller (2000) reported that Lolium multiflorum and Trifolium pratense grew well on a sandy soil containing $11.5 \mu \mathrm{mol} \mathrm{Cd} \mathrm{kg}{ }^{-1}(\mathrm{pH} 5$; C\% 3.2; Clay 5\%) but a silty soil containing $14.3 \mu \mathrm{mol} \mathrm{Cd} \mathrm{kg}{ }^{-1}$ (pH 6.4; C\% 1.1; Clay $20 \%)$ showed a dry matter decrease of $30 \%$ and $20 \%$, respectively. On other polluted silt soil, containing $231 \mu \mathrm{mol} \mathrm{Cd} \mathrm{kg}^{-1}(\mathrm{pH}$ 6.9; C\% 0.6; Clay 18\%) a yield reduction of $65 \%$ in ryegrass and $72 \%$ in red clover were found. On the other hand, in the same experiment Lupinus albus increase of the biomass of $40 \% 231$

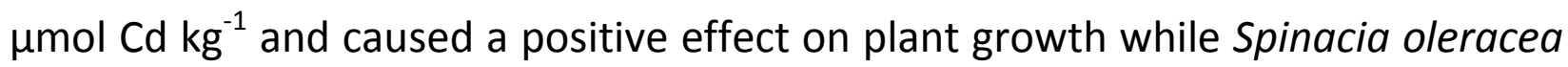
had produced 5 fold less dry matter at $231 \mu \mathrm{mol} \mathrm{Cd} \mathrm{kg}{ }^{-1}$ than as at $11.5 \mu \mathrm{mol} \mathrm{Cd}$ $\mathrm{kg}^{-1}$ soil. To ensure a safe agricultural production the critical level must be known at which a plant is able to grow without effect on yield and quality.

However, threshold value varies significantly in different plants. Healthy plant growth is associated with the $\mathrm{Cd}$ concentration in the plant. Plant species accumulate varying quantities of $\mathrm{Cd}$ in shoot not only in different species of a genus but also among genotypes within a species (Padeken 1998; Keller 2000; Egle 2002; Dunbar et al., 2003). Egle (2002) concluded that Lupinus albus had the lowest $\mathrm{Cd}$ shoot concentration $\left(0.2 \mathrm{mg} \mathrm{kg}^{-1}\right)$ compared to those of Lupinus angustifolius (0.6 mg kg-1) and Lupinus luteus $\left(0.9 \mathrm{mg} \mathrm{kg}^{-1}\right)$ grown on sandy soil $(\mathrm{pH}$ 5.4) with $5.3 \mu \mathrm{mol} \mathrm{kg}{ }^{-1}$ total $\mathrm{Cd}$ concentration. In the same experiment it was remarkable the high $\mathrm{Cd}$ concentration of Lolium multiflorum which measured 5 times higher than in Lupinus albus and from 1.5 to 2.5 times higher than in Lupinus angustifolius and Lupinus luteus. Results of Keller (2000) showed that at $11.5 \mu \mathrm{mol}$ 
$\mathrm{Cd} \mathrm{kg}^{-1}$ and at $14.3 \mu \mathrm{mol} \mathrm{Cd} \mathrm{kg}^{-1}$ Lolium multiflorum and Trifolium pratense with 1.5-3.5 mg kg ${ }^{-1}$ had a low $\mathrm{Cd}$ shoot concentrations, while at $231 \mu \mathrm{mol} \mathrm{Cd} \mathrm{kg}^{-1}$ obtained high $\mathrm{Cd}$ shoot concentrations of $11-13 \mathrm{mg} \mathrm{kg}^{-1}$. Shoot $\mathrm{Cd}$ concentration of two spinach genotypes (Monnopa and Tabu) was from 9 to $48 \mathrm{mg} \mathrm{kg}^{-1}$ significantly higher than those of lupine. Furthermore, $\mathrm{Cd}$ concentration in sunflower kernels of commercial non-oilseed hybrids grown at slightly contaminated soil $\left(3.5 \mu \mathrm{mol} \mathrm{Cd} \mathrm{kg}^{-1}\right.$ ) varied from 0.79 to $1.17 \mathrm{mg} \mathrm{kg}^{-1}$ (Li et al. 1995).

Cadmium toxicity symptoms are puny growth and yellowing of the intercostal fields to necrosis of tissues and characteristic brown surfaces on the leaves and leaf fall (Barcelo \& Poschenrieder; Salt et al., 1995; Dong et al., 2005). Cadmium probably has a negative effect on the process of photosynthesis, by reducing the chlorophyll content (Hassan et al., 2005), and reducing of transpiration (HaagKerwer et al., 1999). Similarly, Cd has an inhibitory effect on the activity of various enzymes (Weigel and Jäger, 1980; Uraguchi et al., 2006), on the functionality of membranes (Kennedy and Consalves, 1987), as well inhibits chlorophyll biosynthesis (Stobart et al., 1985; Van Assche \& Clijsters, 1990; Somashekaraiah et al., 1992). Moreover, Liu et al. (1995) reported damage in the nucleotides via $\mathrm{Cd}$. The appearance of chlorosis due to $\mathrm{Cd}$ supply was also observed in other species (Alcantara et al., 1994), which linked it, to a decrease in net assimilation rate (NAR) for barley (Vassilev et al. 2002; Hassan et al. 2005). Sandalio et al. (2001) reported that the growth inhibition of pea plants was accompanied by a significant decrease in the photosynthesis rate. Antagonistic effects between $\mathrm{Cd}$ and $\mathrm{Zn}, \mathrm{Cu}$, $\mathrm{Mn}$ and Ca during the uptake and accumulation was described by Yang et al. 
(1996) for cereal crops which could also explain the above-mentioned damage symptoms.

Cadmium accumulation in plants has been studied in several species. In most of the plant species, much of the Cd taken up by plants is retained in the root and its translocation to shoot is low. In general, all plants showed higher $\mathrm{Cd}$ concentrations in the roots than in shoots. Roots accumulate much greater amounts of $\mathrm{Cd}$ than shoots and dicotyledonous absorb more $\mathrm{Cd}$ from solution than monocotyledon (Kuboi et al.1986, Inouhe et al 1994). In Lupinus albus is about $15 \mathrm{mg} \mathrm{Cd} \mathrm{kg}^{-1}$ strongly accumulated in roots and only 0.2 is transported to the shoot system. Lupinus angustifolius absorbed $\mathrm{Cd}$ from the rooting medium ( $0.5 \mathrm{mg} \mathrm{Cd} \mathrm{kg}{ }^{-1}$ soil) and the localization of absorbed $\mathrm{Cd}$ is greater in roots (11.5 $\mathrm{mg} \mathrm{Cd} \mathrm{kg}$ ) than in shoots $\left(0.7 \mathrm{mg} \mathrm{Cd} \mathrm{kg}^{-1}\right)$ (Egle 2002). From the above it is understood that root system of plants act as a first barrier of $\mathrm{Cd}$ translocation to the shoot and so the symptoms and biomass reduction appear in the plant at different Cd shoot concentration.

For this study maize, sunflower, flax and spinach species were selected because they showed very different behavior in the study of Padeken (1998). While the plants grew on the same silt soil (pH 7.4; C\% 1.6; Clay 18\%; $\mathrm{Cd} 89 \mu \mathrm{mol} \mathrm{kg}^{-1}$ ) obtained maize $\left(0.62 \mathrm{mg} \mathrm{Cd} \mathrm{kg}^{-1}\right)$ and sunflower $\left(1.99 \mathrm{mg} \mathrm{Cd} \mathrm{kg}{ }^{-1}\right)$ low shoot $\mathrm{Cd}$ concentration while flax (4.87 mg Cd kg${ }^{-1}$ ) and spinach (6.22 mg Cd kg-1) had higher shoot $\mathrm{Cd}$ concentration among 13 species tested. At the same $\mathrm{Cd}$ concentration extracted with $0.1 \mathrm{M} \mathrm{CaCl}_{2}\left(3.4 \mu \mathrm{mol} \mathrm{Cd} \mathrm{kg}^{-1}\right)$ spinach showed a higher $\mathrm{Cd}$ uptake (269 $\mathrm{ng} \mathrm{cm}{ }^{-2}$ ) than maize $\left(17 \mathrm{ng} \mathrm{cm}^{-2}\right)$, so the roots of spinach have a higher activity to use the $\mathrm{Cd}$ concentration in the rhizosphere, resulting in a higher $\mathrm{Cd}$ 
uptake per unit root. This result indicates that spinach root may increase the $\mathrm{Cd}$ concentration in the rhizosphere leading to that higher $\mathrm{Cd}$ uptake per unit of root.

The accumulation of essential heavy metal, like $\mathrm{Mn}$ and $\mathrm{Zn}$ in the shoot depends on the uptake. The heavy metal uptake, in turn, depends on the size of the root system and the influx (Sadana et al., 2003). However, for non-essential heavy metal that is valid for a certain area of $\mathrm{Cd}$ concentration in soil in which the physiology of root system is not adversely affected. In this study, we want to focus on the difference in $\mathrm{Cd}$ uptake of the plant species mentioned above and to determine the effect of soil solution concentration on plant growth and accumulation of $\mathrm{Cd}$ under lower $\left(<10 \mathrm{mg} \mathrm{kg}^{-1}\right) \mathrm{Cd}$ content of the soil. In the experiments we used both monocots and dicots plant species. In the selection of these plants was regarded not only their differences in $\mathrm{Cd}$ shoot accumulation, but also their use after harvest. As for industrial plants their cultivation on contaminated soils could be acceptable, the cultivation of non-industrial plants would be dangerous for fresh consumption. For the risk to humans and animals are particularly important in $\mathrm{Cd}$ concentrations in the usable plant organs, i.e. these are often the seeds that have been studied on their heavy metal concentrations.

Maize as a grain and a $\mathrm{C}_{4}$ plant is cultivated after wheat and rice as the world's third most important grain, and is a staple food in many countries and an important forage plant. In Germany, seventy percent of the cultivated area of maize used for animal feed and the residual processed in the food industry.

The flax oil consists mainly of unsaturated fatty acids (18 C) such as oleic acid (C 18:2) and linoleic acid (C 18:3) that are in demand for the production of 
pharmaceuticals and cosmetics (van den Berg et al., 2004). The ripe dried flax seed and the cold-pressed oil used in nutrition and the manufacture of paints.

Sunflower seeds are used in bread and, above all, the sunflower oil is used as a plant whose oil is very valuable for human consumption. The sunflower oil is rich in oleic acid (C 18:1), a long-chain monounsaturated fatty acid (Flagella et al., 2002), which is of particular importance for the chemical industry.

Spinach is one of the important vegetables grown on soil and can be eaten as a salad as well as a large part of the spinach is used in the food industry as a deepfrozen product on the market. Spinach has a high content of minerals ( $\mathrm{Fe}, \mathrm{Zn}, \mathrm{Ca}$, $\mathrm{K}, \mathrm{Cu}, \mathrm{Mg}, \mathrm{Na}, \mathrm{P})$, vitamins ( $\beta$-carotene, also known as vitamin $\mathrm{A}$, vitamin $\mathrm{B}$ group, vitamin C), fiber, fat and protein.

\subsection{Factors affecting the shoot $C d$ concentration of plants}

Shoot Cd concentration is dependent on:

a) root surface area (RA in $\mathrm{cm}^{-2}$ ) per unit of shoot weight (SDW in g),

b) the relative shoot growth rate $\left(R G R_{S}\right)$,

c) the Cd total net influx $\left(\mathrm{I}_{\mathrm{nt}}\right.$ in $\left.\mathrm{mol} \mathrm{cm} \mathrm{cm}^{-2}\right)$ and

d) the proportion of absorbed $\mathrm{Cd}$ that is translocated from the root to the $\operatorname{shoot}(p)$.

Often only uptake into the shoot is determined and the influx may be named as net shoot influx $\left(\mathrm{I}_{\mathrm{ns}}\right)$ notice that $\mathrm{I}_{\mathrm{ns}}=\mathrm{I}_{\mathrm{nt}} \times p$ 
All these factors can enter mathematically into the following equation (Ney and Tinker 1977):

Shoot Cd concentration $(\mathrm{X})=\frac{R A}{S D W} \cdot \frac{1}{R G R_{S}} \cdot I_{n t} \cdot p$

Keller (2000) found that the shoot Cd concentration of various types of spinach was positive correlated with RA/SDW but in comparison of different species was not given this correlation, i.e. different $\mathrm{Cd}$ levels between species were due to differences in the influx (Egle, 2002). Cadmium influx depends on the uptake kinetics and the effect of the root on $\mathrm{Cd}$ activity (i.e. the effective $\mathrm{Cd}$ concentration) in the soil solution. The uptake kinetics as a factor of $\mathrm{Cd}$ influx from the soil into the root has not been investigated to our knowledge, as is generally considered that significant for heavy metals such as $\mathrm{Cd}$ is the low availability in the soil for the influx. The previous results indicate that differences in $\mathrm{Cd}$ uptake from soil among species may depend on different uptake kinetics and on the way that the root affects the solubility of $\mathrm{Cd}$ in the rhizosphere. Differences in influx are related to the uptake kinetic parameters $I_{\max }$ and $K_{m}$ (Michaelis - Menten kinetics), which result from plants adaptation to Cd concentration (Jungk and Claassen, 1997; Claassen and Steingrobe, 1999; Jungk, 2002). Michaelis - Menten kinetics may not unlimited apply to characterize the $\mathrm{Cd}$ uptake kinetics by plant because there is no point of determining the maximum net influx by adding unrealistic high levels of $\mathrm{Cd}$ to a nutrient solution or soil as $\mathrm{Cd}$ is not an essential but toxic element.

The uptake kinetics is the relationship between the net influx $\left(\mathrm{I}_{\mathrm{n}}\right)$ and the concentration at the root surface, $\mathrm{C}_{\mathrm{L} 0}$, which is in a wide range of concentrations a saturation function (Jungk and Claassen, 1997). 
In the lower concentration range, this relationship is approximately linear for both Cd as well as micro and macro nutrients (Sadana et al., 2005), and can be described as follows:

$I_{n}=\alpha \cdot C_{L o}$

Where $\alpha$ describes the root absorbing power, in $\mathrm{cm} \mathrm{s}^{-1}$ (Nye 1973) and it is the slope of the uptake isotherm (which can be estimated from the ratio of $\mathrm{I}_{\max } / \mathrm{K}_{\mathrm{m}}$ or measured directly, i.e. $\mathrm{I}_{\mathrm{n}} / \mathrm{C}_{\mathrm{LO}}$ ) at the very low concentration. The $\alpha$ value makes comparisons among nutrients and plants easier.

Sadana et al., (2005) reported $\alpha$ value of $\mathrm{Mn} 1.1 \times 10^{-6}-1.7 \times 10^{-6} \mathrm{~cm} \mathrm{~s}^{-1}$ for three wheat cultivars and Zahan (2008) $\alpha$ value $26.2 \times 10^{-6}-41.6 \times 10^{-6} \mathrm{~cm} \mathrm{~s}^{-1}$ for four bread wheat cultivars. For macronutrients, Claassen (2006) mentioned $\alpha$ value of $\mathrm{K}\left(100 \times 10^{-6}-1000 \times 10^{-6} \mathrm{~cm} \mathrm{~s}^{-1}\right.$ for wheat $)$ and $\mathrm{P}\left(200 \times 10^{-6}-1000 \times 10^{-6} \mathrm{~cm} \mathrm{~s}^{-1}\right.$ for oil seed rape). This values show that root absorbing power varies very strong and according to equation $\mathrm{I}_{\mathrm{n}}=\alpha \times \mathrm{C}_{\mathrm{L} 0}$ at the same concentration at the root surface the influx of $\mathrm{P}$ or $\mathrm{K}$ will be much higher than of $\mathrm{Mn}$. This aspect of uptake kinetics has not yet been considered for $\mathrm{Cd}$ and it is important to find how high $\mathrm{Cd}$ concentrations in plants are caused by high $\alpha$ values.

The influx also depends on how much $\mathrm{Cd}$ the soil can supply to the root, i.e. it depends on the transport properties of the soil. The result is a combination of plant and soil properties that influence finally the $\mathrm{Cd}$ influx. Therefore, simple relationships often cannot explain observed phenomena. To overcome this problem, several authors have used mathematical simulation to improve the understanding of the complexity involved in the process of nutrient uptake by plant roots growing in soil (Claassen et al., 1986; Claassen and Steingrobe, 1999). 
These models are based on movement of nutrients from soil to roots by means of mass flow and diffusion and on nutrient-uptake kinetics, mostly following Michaelis - Menten kinetics. The model will help to understand why plants differ in their $\mathrm{Cd}$ accumulation because besides the calculated $\mathrm{Cd}$ uptake by plants, the $\mathrm{Cd}$ dynamics in the rhizosphere is calculated. Therefore, it will be possible, for example, to recognize to which extent different species lower the $\mathrm{Cd}$ concentration in the rhizosphere. Furthermore, we aim to evaluate the input parameters that influenced $\mathrm{Cd}$ uptake and transport and to assess the importance of various parameters in Cd uptake.

\subsection{Investigation of hypotheses in this research}

The conclusion from the previous is that $\mathrm{Cd}$ shoot accumulation is dependent on $\mathrm{Cd}$ uptake. The $\mathrm{Cd}$ uptake in turn depends on the size of the root system and the $\mathrm{Cd}$ influx. In this work we want to focus mainly on the difference in Cd influx of different plant species grown in soil and to study the following hypothesis.

- Cadmium influx is strongly affected by the Cd uptake kinetics ( $\alpha$-value, root absorbing power).

- Cadmium influx can be quantitatively described by a deterministic model (NST 3.0).

- Cadmium influx is influenced by rhizosphere effects ( $\mathrm{Cd}$ solubilization in the rhizosphere). 


\section{Shoot CAdMIUM CONCENTRATION OF SOIL Grown Plants as Related to their RoOt PROPERTIES}

\subsection{Indroduction}

Cadmium (Cd) is the $64^{\text {th }}$ most abundant elements in the Earth' crust (Sarkar, 2002), and the study of $\mathrm{Cd}$ uptake by plants has been done because of its potential risk for human health through the food chain. To assess the risk it is necessary to know the plant $\mathrm{Cd}$ concentration and to which extent it is influenced by factors such as soil properties $(\mathrm{pH}$, clay content, humic substances, buffering capacity, water content, Cd content in soil, Eh) and plant properties (root activity, uptake, tolerance or sensitivity, translocation from root to shoot, plant age, parts of the plant). The Cd uptake of plants depends for one on $\mathrm{Cd}$ availability in soil, and for the other it differs among species, and among genotypes of the same species and therefore Cd accumulation in the shoot varies greatly (Wang 2002, Simmons et al., 2003). These studies have also been used to obtain tolerant plants that can grow on Cd contaminated soils with large amounts of $\mathrm{Cd}$. However, the reasons responsible for such variations in shoot $\mathrm{Cd}$ concentration are insufficiently understood.

Padeken (1998) reported that plants grown in Cd contaminated soil with total content of $10 \mathrm{mg} \mathrm{kg}^{-1}$ differed in their shoot Cd concentration. Maize with $0.62 \mathrm{mg}$ $\mathrm{Cd} \mathrm{kg}^{-1}$ and sunflower with $1.99 \mathrm{mg} \mathrm{Cd} \mathrm{kg}^{-1}$ had low shoot $\mathrm{Cd}$ concentration while 
flax with $4.87 \mathrm{mg} \mathrm{Cd} \mathrm{kg}^{-1}$ and spinach with $6.22 \mathrm{mg} \mathrm{Cd} \mathrm{kg}^{-1}$ had high shoot $\mathrm{Cd}$ concentration among 13 species tested. The high $\mathrm{Cd}$ accumulation was not related to a high root / shoot ratio because sunflower had a ration of $133 \mathrm{~cm}^{2} \mathrm{~g}^{-1}$ and maize of $117 \mathrm{~cm}^{2} \mathrm{~g}^{-1}$ while spinach with the higher shoot concentration had a root / shoot ratio of only $28 \mathrm{~cm}^{2} \mathrm{~g}^{-1}$ and flax with $87 \mathrm{~cm}^{2} \mathrm{~g}^{-1}$ had a middle value. Therefore, spinach had a higher $\mathrm{Cd}$ uptake per unit root surface area (269 $\mathrm{ng} \mathrm{cm}^{-2}$ ) than maize $\left(17 \mathrm{ng} \mathrm{cm}^{-2}\right.$ ). This result may indicate that spinach roots may increase the $\mathrm{Cd}$ concentration in the rhizosphere or change the $\mathrm{Cd}$ chemistry in the rhizosphere leading to that higher $\mathrm{Cd}$ uptake per unit of root. Besides the $\mathrm{Cd}$ availability in soil the $\mathrm{Cd}$ influx depends also on the root absorbing power, $\alpha$, defined by the relationship of the net $\mathrm{Cd}$ influx, $\mathrm{I}_{\mathrm{n}}$, and the $\mathrm{Cd}$ concentration in the solution at the root surface, $\mathrm{C}_{\mathrm{L} 0},\left(\mathrm{I}_{\mathrm{n}}=\alpha \times \mathrm{C}_{\mathrm{L} O}\right)$. Plants may differ in their root absorbing power. A variation of $\alpha$ values could be significant for $\mathrm{Cd}$ uptake from soil. This aspect of $\mathrm{Cd}$ uptake from soil has not been considered. Besides the $\mathrm{Cd}$ influx, Cd uptake also depends on the size of the root system. Furthermore, in contrast to essential heavy metal, like $\mathrm{Mn}, \mathrm{Zn}$, for non-essential heavy metals as $\mathrm{Cd}$, a large part of the total $\mathrm{Cd}$ absorbed is retained in the root and only a smaller portion is transferred to the shoot (Guo et al., 1995; Padeken, 1998; Grant et al., 1998; Keller, 2000; Egle, 2002). A difference in retention of $\mathrm{Cd}$ in the roots may be a reason for different $\mathrm{Cd}$ concentrations in the shoot. A lower $\mathrm{Cd}$ concentration in the shoot could furthermore be explained trough a high dilution effect due to a higher relative growth rate. However, little efforts have been made to study simultaneously the possible mechanisms causing the differences in Cd uptake.

The objective was to study to which extent differences in $\mathrm{Cd}$ accumulation of different plant species are due to the size of root system, the Cd influx, the growth 
rate of the shoot and to the proportion of the $\mathrm{Cd}$ taken up that is translocated to the shoot. It was also investigated the effect of plants on $\mathrm{Cd}$ availability or solubility in soil and its relation to $\mathrm{Cd}$ uptake by the plants. For this, maize, sunflower, flax, and spinach were grown on a soil with three levels of $\mathrm{Cd}$ addition and shoot growth, Cd concentration, and root growth were determined. Two harvests were performed in order to be able to measure rates of growth and of $\mathrm{Cd}$ uptake.

\subsection{Materials und Methods}

A soil culture pot experiment was conducted in a climate chamber under controlled conditions (Temperature day/night $25^{\circ} \mathrm{C} / 18{ }^{\circ} \mathrm{C}$, relative humidity day/night: 31\% / 60\%, light intensity: day/night 16h / 8h, PAR $240 \mu \mathrm{mol} \mathrm{m} \mathrm{m}^{-2}$ ) using four plants species (Zea mays L., cv. Cascadas, Helianthus annuus L., cv. Ikarus, Linum usitatissimum L.ssp. usitatissimum, cv. Gold Merchant, Spinacia oleracea L., Cv. Monnopa) and three $\mathrm{Cd}$ additions to the soil $(0,14$, and $40 \mu \mathrm{mol}$ $\mathrm{kg}^{-1}$ soil).

The soil used was a sandy soil $\left(\mathrm{pH}_{\mathrm{CaCl} 2} 4.5,2.8 \% \mathrm{C}, 5 \%\right.$ clay). Pots were filled with 3 kg soil and for each $\mathrm{Cd}$ addition, one pot was kept unplanted as a control. After $\mathrm{Cd}$ addition and basic fertilization of $80 \mathrm{mg} \mathrm{N} \mathrm{kg}^{-1}$ as $\mathrm{Ca}\left(\mathrm{NO}_{3}\right)_{2} * 4 \mathrm{H}_{2} \mathrm{O}, 100 \mathrm{mg} \mathrm{P} \mathrm{kg}^{-1}$ as $\mathrm{Ca}\left(\mathrm{H}_{2} \mathrm{PO}_{4}\right)_{2} * \mathrm{H}_{2} \mathrm{O}, 80 \mathrm{mg} \mathrm{K} \mathrm{kg}{ }^{-1}$ as $\mathrm{K}_{2} \mathrm{SO}_{4}$, and $10 \mathrm{mg} \mathrm{Mg} \mathrm{kg}{ }^{-1}$ as $\mathrm{MgSO}_{4} * 7 \mathrm{H}_{2} \mathrm{O}$, soil was incubated at $15 \%$ moisture $(w / w)$ for 1 week until $\mathrm{Cd}$ concentration in soil solution had stabilized. Then maize, sunflower, flax, and spinach were sown into the pots. The soil was kept at $15 \%$ moisture by daily watering of the pots. Plants were harvested after 28 days (harvest I) and after 43 days (harvest II) after sowing. Two harvests were necessary in order to be able to calculate root and shoot growth rates and $\mathrm{Cd}$ influx. 
Cadmium additions resulted in $\mathrm{Cd}$ soil solution concentrations of $0.04,0.68$ and

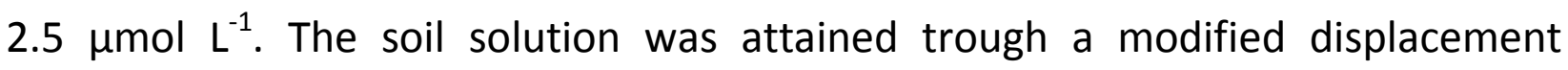
technique after Adams (1974). For this, moist soil was taken from unplanted and planted pots. The soil was sieved and about $300 \mathrm{~g}$ were transferred into $250 \mathrm{~mL}$ cylinder, with a drain hole at the bottom covered with a filter paper. At the top of the soil column a $4 \%$ KCNS solution was added drop by drop with a rate of about 5 $\mathrm{mL} \mathrm{h}^{-1}$ by a peristaltic pump. The KCNS is used to determine whether the displaced solution is the pure soil solution or if it is contaminated. A possible contamination of the displaced solution is detected by adding a few drops of $5 \% \mathrm{FeCl}_{3}$ that in the presence of KCNS produces an intensive red color. Filtrates of soil solution were analyzed for $\mathrm{Cd}$ concentration using graphite furnace atomic absorption spectrometer GFAAS. The limits of detection were $2 \mu \mathrm{g} \mathrm{L^{-1 }}$.

At each harvest, shoots were cut at the soil level and dried at $105^{\circ} \mathrm{C}$. The dried samples were weighed, ground in a mill, and digested in $\mathrm{HNO}_{3}$ under pressure at $180^{\circ} \mathrm{C}$. Digests were analyzed for $\mathrm{Cd}$ concentration using flame atomic absorption spectroscopy FAAS. The limits of detection were $2 \mathrm{mg} \mathrm{L}^{-1}$.

The roots were separated from soil by washing and flooding over sieves, and then cleaned of any foreign material. The surface water was removed by keeping them between two filter papers. The fresh root weight was recorded and $0.8 \mathrm{~g}$ samples were preserved in $20 \%$ ethanol for later measurement of the root length by the line intersect method of Tennant (1975).

The net influx $\left(I_{n}\right)$ was calculated using the following equation (Williams 1948) 


$$
I_{n}=\frac{\left(U_{I I}-U_{I}\right) \cdot \ln \left(\frac{R A_{I I}}{R A_{I}}\right)}{\left(t_{I I}-t_{I}\right) \cdot\left(R A_{I I}-R A_{I}\right)}
$$

where $U$ is shoot $C d$ content in $\mu \mathrm{mol}$ plant ${ }^{-1}, R A$ is root-surface area per plant in $\mathrm{cm}^{2}, \mathrm{t}$ is time of harvest in $\mathrm{s}$, and subscripts I and II refer to first and second harvest, respectively. Assuming exponential growth, the relative growth rate of the shoot $\left(R G R_{S}\right)$ was calculated:

$$
R G R_{S}=\frac{\ln \left(\frac{S D W_{I I}}{S D W_{I}}\right)}{t_{I I}-t_{I}}
$$

where SDW is the shoot dry weight and $t_{1}$ and $t_{\|}$are time of the first and second harvest, respectively.

Assuming a specific gravity for roots of $1 \mathrm{~g} \mathrm{~cm}^{-3}$, mean root radius $\left(r_{0}\right)$ was calculated using the following equation:

$$
r_{0}=\sqrt{\frac{R F W}{\pi \cdot R L}}
$$

where RFW is the root fresh weight in $\mathrm{g}$ and $\mathrm{RL}$ is root length in $\mathrm{cm}$.

Mean half distance among neighboring roots $\left(r_{1}\right)$ was calculated from the formula:

$$
r_{1}=\sqrt{\frac{V_{S}}{\pi \cdot R L}}
$$

where $\mathrm{V}_{\mathrm{s}}$ is soil volume in $\mathrm{cm}^{3}$ and $\mathrm{RL}$ is root length in $\mathrm{cm}$. 
Factors determining the shoot $\mathrm{Cd}$ concentration $(X)$ of plants. Making the simplification that over time $X$ does not change much, it can be shown (Ney and Tinker 1977) that $X$ depends on root surface area (RA) per unit of shoot weight (SDW), the relative shoot growth rate $\left(R G R_{s}\right)$, the $C d$ total net influx $\left(I_{n t}\right)$ and the proportion of absorbed $\mathrm{Cd}$ that is translocated from the root to the shoot $(p)$.

$$
\text { Shoot Cd concentration }(\mathrm{X})=\frac{R A}{S D W} \cdot \frac{1}{R G R_{S}} \cdot I_{n t} \cdot p
$$

Often only uptake into the shoot is determined and the influx may be named as net shoot influx $\left(\operatorname{In}_{\mathrm{s}}\right)$, notice that $\operatorname{In}_{\mathrm{s}}=\operatorname{In}_{\mathrm{t}} \times p$

For each treatment, five seedlings were grown in pots with four replicates per treatment for each harvest in a completely randomized design. The ANOVA was run with the statistic program SigmaStat 5.0.

\subsection{Results}

The toxic symptoms found included interveinal chlorosis of the leaf (spinach), necrotic leaf spots on the leaves and leaf fall (flax) when exposed to high $\mathrm{Cd}$ stress. Roots were brown at high Cd addition (the roots were slightly blackened at their tips). Figure 2-1 shows the effect of $\mathrm{Cd}$ addition to the soil on the shoot dry weight (SDW) expressed relative to the un-contaminated soil. Relative SDW were chosen for a better comparison among species. It can be seen that at the low $\mathrm{Cd}$ addition of $14 \mu \mathrm{mol} \mathrm{kg}$ there was small growth stimulation for three species, which was even significant for flax. At $40 \mu \mathrm{mol} \mathrm{Cd} \mathrm{kg}^{-1}$ soil large differences among species in relative SDW appeared. Maize and sunflower showed little to no yield depression, while the yield of flax and spinach was decreased $20 \%$ and $40 \%$ 
respectively. Flax and spinach were therefore the more sensitive species to $\mathrm{Cd}$ toxicity in soil.

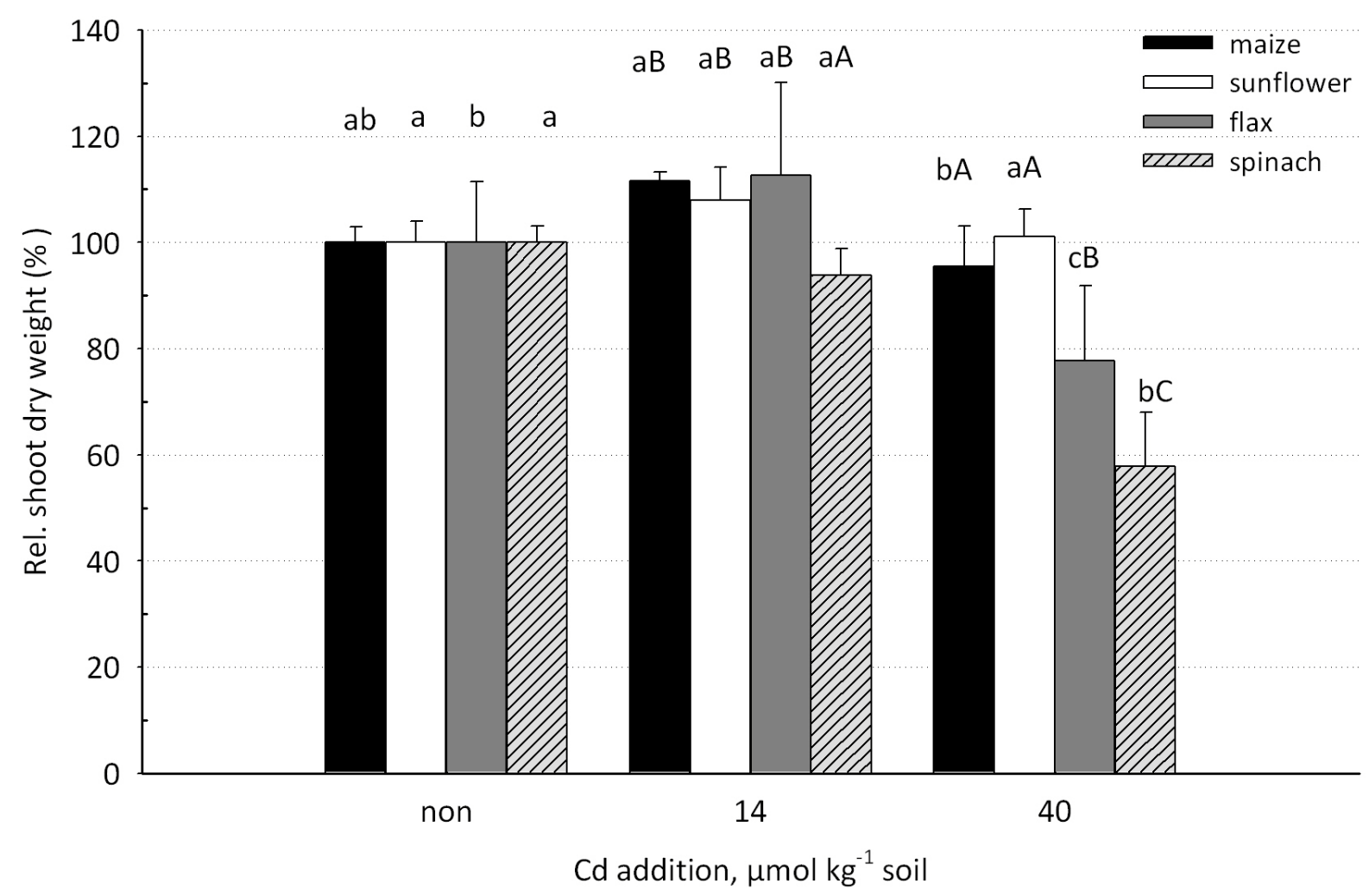

Figure 2-1 Relative shoot dry weight of plants after $43 \mathrm{~d}$ growing at different $\mathrm{Cd}$ addition to the soil (100\% were $7.1 \mathrm{~g} \mathrm{plant}^{-1}$ for maize, $3.4 \mathrm{~g} \mathrm{plant}^{-1}$ for sunflower, $2.2 \mathrm{~g} \mathrm{plant}^{-1}$ for flax and $4.1 \mathrm{~g} \mathrm{plant}^{-1}$ for spinach). Different upper case letters show significant differences among plants at the same $\mathrm{Cd}$ addition. Different lower case letters show significant differences of the same plant at different $\mathrm{Cd}$ additions ( $\mathrm{p} \leq 0.05$; Student-Newmann-Keuls method).

Table 2-1 shows the accumulation of $\mathrm{Cd}$ in shoots and roots of the four species studied. The $\mathrm{Cd}$ concentration in shoots and roots were in general similar at first and second harvest. For the same species, the $\mathrm{Cd}$ concentration in shoot, and similarly in roots increased about linearly with the $\mathrm{Cd}$ addition to the soil without any sign of saturation. Large differences of $\mathrm{Cd}$ concentration in shoot, as well as in roots were found among species. 
Table 2-1 Root and shoot Cd concentration and content after $28 \mathrm{~d}$ and $\mathbf{4 3} \mathrm{d}$ of growth at different $\mathrm{Cd}$ addition to the soil. Translocation to shoot $(p)$ is shoot $\mathrm{Cd}$ content expressed as \% of total plant $\mathrm{Cd}$. Different upper case letters show significant differences among plants at the same $\mathrm{Cd}$ addition. Different lower case letters show significant differences of the same plant at different $\mathrm{Cd}$ additions ( $\mathrm{p} \leq \mathbf{0 . 0 5}$; Student-Newmann-Keuls method, $\mathrm{n}$. $d$.: not determined).

\begin{tabular}{|c|c|c|c|c|c|c|}
\hline Plant & $\begin{array}{c}\mathrm{Cd} \\
\text { addition } \\
\mu \mathrm{mol} \mathrm{kg}^{-1} \\
\end{array}$ & $\begin{array}{c}\text { Shoot Cd } \\
\text { concentration } \\
\mu \mathrm{g} \mathrm{g}^{-1}\end{array}$ & $\begin{array}{c}\text { Root Cd } \\
\text { concentration } \\
\mu \mathrm{g} \mathrm{g}^{-1}\end{array}$ & $\begin{array}{c}\text { Shoot Cd } \\
\text { content } \\
\mu \mathrm{g} \mathrm{pl} \mathbf{l}^{-1}\end{array}$ & $\begin{array}{c}\text { d } \text { Root Cd } \\
\text { content } \\
\mu g \text { pl }^{-1}\end{array}$ & $\begin{array}{c}\text { Traslocation } \\
(p) \\
\% \\
\end{array}$ \\
\hline \multicolumn{7}{|c|}{ Harvest I: 28 days after germination } \\
\hline Maize & non & $0.1 \mathrm{aA}$ & n. d. & $0.2 \mathrm{aA}$ & n. d. & n. d. \\
\hline Sunflower & non & $0.7 \mathrm{aB}$ & $0.9 \mathrm{aA}$ & $0.4 \mathrm{aB}$ & $0.2 \mathrm{aA}$ & $74 \mathrm{aA}$ \\
\hline Flax & non & $1.4 \mathrm{aB}$ & $0.6 \mathrm{aA}$ & $1.0 \mathrm{aC}$ & $0.1 \mathrm{aA}$ & $88 \mathrm{bC}$ \\
\hline Spinach & non & $1.3 \mathrm{aB}$ & $1.1 \mathrm{aA}$ & $1.4 \mathrm{aD}$ & $0.4 \mathrm{aB}$ & $80 \mathrm{aB}$ \\
\hline Maize & 14 & $2.4 \mathrm{bA}$ & n. d. & $4.3 \mathrm{bA}$ & n. d. & n. d. \\
\hline Sunflower & 14 & $13.9 \mathrm{bB}$ & $16.9 \mathrm{bA}$ & $9.7 \mathrm{bB}$ & $4.4 \mathrm{bA}$ & 69 aA \\
\hline Flax & 14 & $26.1 \mathrm{bC}$ & $18.4 \mathrm{bAB}$ & $16.1 \mathrm{bC}$ & $3.8 \mathrm{bA}$ & $81 \mathrm{aB}$ \\
\hline Spinach & 14 & $33.6 \mathrm{bD}$ & $24.3 \mathrm{bB}$ & $36.7 \mathrm{bD}$ & $5.8 \mathrm{bB}$ & $86 \mathrm{bB}$ \\
\hline Maize & 40 & $14.3 \mathrm{cA}$ & n. d. & $20.2 \mathrm{cA}$ & n. d. & n. d. \\
\hline Sunflower & 40 & $30.4 \mathrm{cB}$ & $44.1 \mathrm{cA}$ & $20.4 \mathrm{cA}$ & $8.8 \mathrm{cAB}$ & $70 \mathrm{aA}$ \\
\hline Flax & 40 & $71.4 \mathrm{cC}$ & $74.4 \mathrm{cB}$ & $32.4 \mathrm{cB}$ & $9.6 \mathrm{cBC}$ & $81 \mathrm{aB}$ \\
\hline Spinach & 40 & $106.3 \mathrm{cD}$ & $79.5 \mathrm{cB}$ & $62.8 \mathrm{cC}$ & $7.8 \mathrm{bA}$ & $89 \mathrm{bC}$ \\
\hline \multicolumn{7}{|c|}{ Harvest II: 43 days after germination } \\
\hline Maize & non & $0.06 \mathrm{aA}$ & $0.35 \mathrm{aA}$ & $0.4 \mathrm{aA}$ & $0.8 \mathrm{aB}$ & $35 \mathrm{aA}$ \\
\hline Sunflower & non & $0.4 \mathrm{aB}$ & $0.5 \mathrm{aB}$ & $1.2 \mathrm{aB}$ & $0.7 \mathrm{aB}$ & $65 \mathrm{bB}$ \\
\hline Flax & non & $0.9 \mathrm{aB}$ & $0.3 \mathrm{aA}$ & $2.0 \mathrm{aC}$ & $0.3 \mathrm{aA}$ & $87 \mathrm{cC}$ \\
\hline Spinach & non & $0.8 \mathrm{aB}$ & $1.5 \mathrm{aC}$ & $3.4 \mathrm{aD}$ & $1.6 \mathrm{aC}$ & $68 \mathrm{aB}$ \\
\hline Maize & 14 & $1.2 \mathrm{bA}$ & $2.7 \mathrm{bA}$ & $10.0 \mathrm{bA}$ & $6.3 \mathrm{bA}$ & $60 \mathrm{bA}$ \\
\hline Sunflower & 14 & $9.7 \mathrm{bB}$ & $14.2 \mathrm{bB}$ & $35.8 \mathrm{bB}$ & $15.2 \mathrm{bB}$ & $70 \mathrm{cB}$ \\
\hline Flax & 14 & $24.6 \mathrm{bC}$ & $16.5 \mathrm{bB}$ & $61.2 \mathrm{bC}$ & $16.8 \mathrm{bc}$ & $78 \mathrm{bc}$ \\
\hline Spinach & 14 & $34.4 \mathrm{bD}$ & $21.5 \mathrm{bC}$ & L32.2 bD & $25.5 \mathrm{bD}$ & $84 \mathrm{bD}$ \\
\hline Maize & 40 & $8.0 \mathrm{cA}$ & $12.6 \mathrm{cA}$ & $54.3 \mathrm{cA}$ & $26.8 \mathrm{cA}$ & $67 c B$ \\
\hline Sunflower & 40 & $25.8 \mathrm{cB}$ & $48.2 \mathrm{cB}$ & $88.1 \mathrm{cB}$ & $61.9 \mathrm{cC}$ & 59 aA \\
\hline Flax & 40 & $66.4 \mathrm{cC}$ & $98.3 \mathrm{cC}$ & $113.4 \mathrm{cC}$ & $56.2 \mathrm{cC}$ & $67 \mathrm{aB}$ \\
\hline Spinach & 40 & $105.1 \mathrm{cD}$ & $93.5 \mathrm{cC}$ & $247.0 \mathrm{cD}$ & $43.0 \mathrm{cB}$ & $85 b c$ \\
\hline
\end{tabular}


For example at the second harvest at the lower $\mathrm{Cd}$ addition, the shoot $\mathrm{Cd}$ concentration was $1.2 \mu \mathrm{g} \mathrm{g}^{-1}$ for maize and $34.4 \mu \mathrm{g} \mathrm{g}^{-1}$ for spinach and the high $\mathrm{Cd}$ addition, the values were $8 \mu \mathrm{g} \mathrm{g}^{-1}$ and $105 \mu \mathrm{g} \mathrm{g}^{-1}$ respectively. Spinach accumulated 13 to 30 times more $\mathrm{Cd}$ in the shoot than maize. Sunflower and flax were in between.

The differences in root $\mathrm{Cd}$ concentration behaved similarly but the differences were not so large. Concerning the distribution of $\mathrm{Cd}$ within the plant, i.e. between shoot and root, it can be seen that for maize and sunflower, the concentration in the root is up to two times higher than in the shoot. In contrast, for flax and spinach the $\mathrm{Cd}$ concentration is higher in the shoots than in the roots at low $\mathrm{Cd}$ addition but at high $\mathrm{Cd}$ addition for flax the $\mathrm{Cd}$ concentration of the roots became higher than in the shoots and for spinach shoot and root $\mathrm{Cd}$ concentration were similar. Cadmium translocation to the shoot varied from $60 \%$ to $85 \%$, spinach showing the highest value.This shows that spinach has a lower capacity to retain Cd in the roots, i.e. only $15 \%$ compared to $40 \%$ of maize.

Table 2-2 shows the effect of $\mathrm{Cd}$ on root growth of the four plants species. The root length density $\left(R L_{v}\right)$ characterizes the size of the root system since all plants grew in the same volume of soil. The $R L_{V}$ allows also calculating the half distance between neighboring roots $\left(r_{1}\right)$. It can be seen that maize and sunflower had larger root systems than flax and spinach at all Cd levels. The addition of Cd of 14 $\mu \mathrm{mol} \mathrm{kg} \mathrm{g}^{-1}$ had a stimulating effect on root growth except in sunflower where $\mathrm{RL}_{\mathrm{V}}$ stayed constant. At high $\mathrm{Cd}$ addition, this stimulating effect was still there for maize but in spinach, a strong decrease of almost $50 \%$ occurred. The half distance between neighboring roots ranged mostly from $0.1 \mathrm{~cm}$ to $0.2 \mathrm{~cm}$ except at high $\mathrm{Cd}$ addition it was $0.3 \mathrm{~cm}$ for spinach. This shows that the whole soil was close to a 
root so that the activity of the root could have influenced the properties of the whole soil volume. The root radius $\left(r_{0}\right)$ differed somewhat among species and decreased with $\mathrm{Cd}$ addition around $5 \%$ to $10 \%$.

Table 2-2 Root length density $\left(R L_{v}\right)$, root radius $\left(r_{0}\right)$ and half distance between neighboring roots $\left(r_{1}\right)$ at different $\mathrm{Cd}$ addition to the soil at second harvest (43d after germination). Different upper case letters show significant differences among plants at the same Cd addition. Different lower case letters show significant differences of the same plant at different $\mathrm{Cd}$ additions ( $p \leq 0.05$; Student-Newmann-Keuls method).

\begin{tabular}{|c|c|c|c|c|}
\hline Plant & $\begin{array}{c}\text { Cd addition } \\
\mu \mathrm{mol} \mathrm{kg}{ }^{-1}\end{array}$ & $\begin{array}{c}\mathrm{RL}_{\mathrm{V}} \\
\mathrm{cm} \mathrm{cm}^{-3}\end{array}$ & $\begin{array}{l}r_{1} \\
\mathrm{~cm}\end{array}$ & $\begin{array}{l}r_{0} \\
\mathrm{~cm}\end{array}$ \\
\hline Maize & non & $20 \mathrm{Da}$ & $0.13 \mathrm{Ab}$ & $0.024 \mathrm{Cb}$ \\
\hline Sunflower & non & $17 \mathrm{Cbc}$ & $0.14 \mathrm{Ba}$ & $0.018 \mathrm{Ab}$ \\
\hline Flax & non & $9 \mathrm{Ba}$ & $0.19 \mathrm{Cb}$ & $0.019 \mathrm{Bb}$ \\
\hline Spinach & non & $6 \mathrm{Ab}$ & $0.23 \mathrm{Db}$ & $0.024 \mathrm{Cb}$ \\
\hline Maize & 14 & $28 \mathrm{Dc}$ & $0.11 \mathrm{Aa}$ & $0.020 \mathrm{Ca}$ \\
\hline Sunflower & 14 & $16 \mathrm{Cab}$ & $0.14 \mathrm{Ba}$ & $0.017 \mathrm{Aa}$ \\
\hline Flax & 14 & $13 \mathrm{Bb}$ & $0.16 \mathrm{Ca}$ & $0.019 \mathrm{Bb}$ \\
\hline Spinach & 14 & $8 \mathrm{Ac}$ & $0.20 \mathrm{Da}$ & $0.022 \mathrm{Da}$ \\
\hline Maize & 40 & $25 \mathrm{Db}$ & $0.11 \mathrm{Aa}$ & $0.021 \mathrm{Ca}$ \\
\hline Sunflower & 40 & $18 \mathrm{Cc}$ & $0.14 \mathrm{Ba}$ & $0.017 \mathrm{Aa}$ \\
\hline Flax & 40 & $8 \mathrm{Ba}$ & $0.21 \mathrm{Cc}$ & $0.018 \mathrm{Ba}$ \\
\hline Spinach & 40 & $3 \mathrm{Aa}$ & $0.32 \mathrm{Dc}$ & $0.023 \mathrm{Da}$ \\
\hline
\end{tabular}

The $\mathrm{Cd}$ influx into roots can be estimated by the increase of $\mathrm{Cd}$ content of the plants (shoot plus roots) with time divided by the root surface area and the time 
of uptake. In soil-grown plants, the $\mathrm{Cd}$ content of the roots cannot always be determined reliably because of their possible contamination with Cd-rich soil particles. Therefore in this paper to calculate the $\mathrm{Cd}$ influx only the increase of $\mathrm{Cd}$ content of the shoots was used and the influx is named "shoot influx". The results in Fig. 2-2 show that the Cd shoot influx for sunflower and flax increased linearly with the $\mathrm{Cd}$ addition but for spinach and maize, the increase was more than proportional. For a 3-fold increase of $\mathrm{Cd}$ addition $\left(14\right.$ to $\left.40 \mu \mathrm{mol} \mathrm{kg}{ }^{-1}\right)$ the $\mathrm{Cd}$ influx increased 8-fold (from $0.2 \times 10^{-16}$ to $1.6 \times 10^{-16} \mathrm{~mol} \mathrm{~cm}^{-2} \mathrm{~s}^{-1}$ ) for maize and 6 -fold (from $7.5 \times 10^{-16}$ to $42 \times 10^{-16} \mathrm{~mol} \mathrm{~cm}^{-2} \mathrm{~s}^{-1}$ ) for spinach.

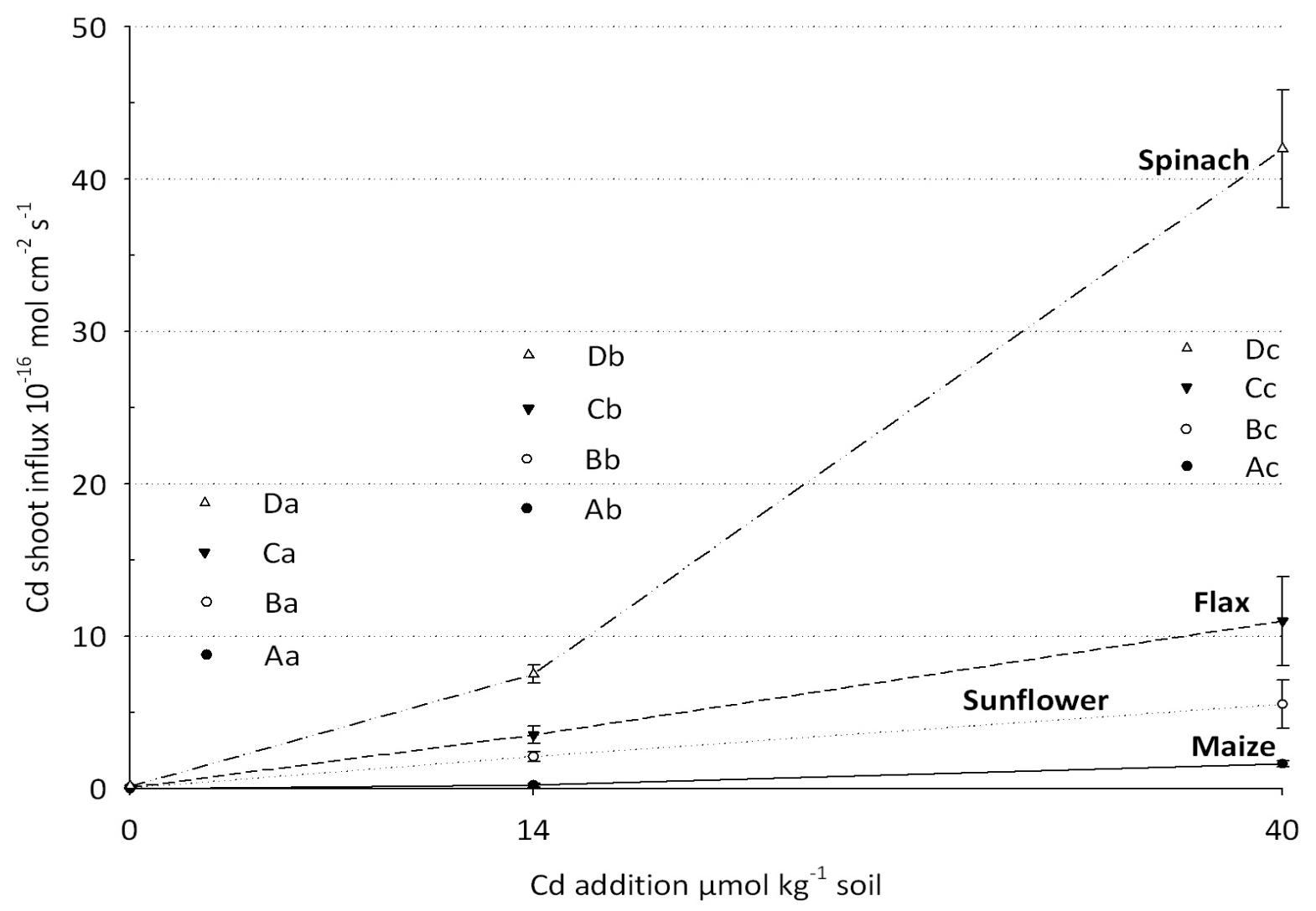

Figure 2-2 Shoot $\mathrm{Cd}$ influx at different $\mathrm{Cd}$ addition to the soil. Different upper case letters show significant differences among plants at the same $\mathrm{Cd}$ addition. Different lower case letters show significant differences of the same plant at different $\mathrm{Cd}$ additions ( $p \leq 0.05$; Student-Newmann-Keuls method). 
At all Cd levels, the influx differed significantly among all species, maize always having the lowest and spinach the highest $\mathrm{Cd}$ influx. The $\mathrm{Cd}$ influx of spinach was around 30 times higher than that of maize. As already seen in Table 2.1 the shoot Cd concentration differed among species by a factor of up to 30 . Table 2-3 summaries the factors that according to equation 2-5 would be responsible for those differences.

Table 2-3 Plant factors determining the shoot Cd concentration; root area / shoot dry weight ratio (RA / SDW), shoot growth rate ( $\left.R G R_{S}\right)$ and shoot influx at different Cd addition to the soil after $\mathbf{4 3} \mathrm{d}$ of growth. Different upper case letters show significant differences among plants at the same $\mathrm{Cd}$ addition. Different lower case letters show significant differences of the same plant at different $\mathrm{Cd}$ additions ( $p \leq 0.05$; Student-Newmann-Keuls method).

\begin{tabular}{|c|c|c|c|c|c|}
\hline Plant & $\begin{array}{c}\text { Cd add } \\
\mu \mathrm{mol} \mathrm{kg}^{-1}\end{array}$ & $\begin{array}{l}\text { shoot Cd } \\
\mathrm{mg} \mathrm{kg}^{-1}\end{array}$ & $\begin{array}{c}\mathrm{RA} / \mathrm{SDW} \\
\mathrm{cm}^{2} \mathrm{~g}^{-1}\end{array}$ & $\begin{array}{l}\mathrm{RGR}_{\mathrm{s}} \\
10^{-6} \mathrm{~s}^{-1}\end{array}$ & $\begin{array}{l}\text { Shoot Influx } \\
10^{-16} \mathrm{~mol} \mathrm{~cm}^{-2} \mathrm{~s}^{-1}\end{array}$ \\
\hline Maize & non & $0.06 \mathrm{aA}$ & $408 \mathrm{aB}$ & $1.30 \mathrm{aB}$ & $0.01 \mathrm{aA}$ \\
\hline Sunflower & non & $0.4 \mathrm{aB}$ & $534 \mathrm{bD}$ & $1.40 \mathrm{aB}$ & $0.06 \mathrm{aB}$ \\
\hline Flax & non & $0.9 \mathrm{aB}$ & $463 \mathrm{aC}$ & $0.81 \mathrm{aA}$ & $0.09 \mathrm{aC}$ \\
\hline Spinach & non & $0.8 \mathrm{aB}$ & $236 \mathrm{aA}$ & $0.90 \mathrm{aA}$ & $0.17 \mathrm{aD}$ \\
\hline Maize & 14 & $1.2 \mathrm{bA}$ & $433 \mathrm{abB}$ & $1.34 \mathrm{aB}$ & $0.2 \mathrm{bA}$ \\
\hline Sunflower & 14 & $9.7 \mathrm{bB}$ & $437 \mathrm{aB}$ & $1.37 \mathrm{aB}$ & $2.1 \mathrm{bB}$ \\
\hline Flax & 14 & $24.6 \mathrm{bC}$ & $588 c C$ & $1.01 \mathrm{bA}$ & $3.5 \mathrm{bc}$ \\
\hline Spinach & 14 & $34.4 \mathrm{bD}$ & $305 \mathrm{bA}$ & $0.86 \mathrm{aA}$ & $7.5 \mathrm{bD}$ \\
\hline Maize & 40 & $8.0 \mathrm{cA}$ & $475 \mathrm{bBC}$ & $1.40 \mathrm{aB}$ & $1.6 \mathrm{cA}$ \\
\hline Sunflower & 40 & $25.8 \mathrm{cB}$ & $543 \mathrm{bD}$ & $1.35 \mathrm{aB}$ & $5.6 \mathrm{cB}$ \\
\hline Flax & 40 & $66.4 c C$ & 521 bCD & $0.96 \mathrm{bA}$ & $11.0 \mathrm{cC}$ \\
\hline Spinach & 40 & $105.1 \mathrm{cD}$ & $197 \mathrm{aA}$ & $0.94 \mathrm{aA}$ & $42.0 \mathrm{cD}$ \\
\hline
\end{tabular}


It can be seen that for the root-shoot ratio the highest and lowest value differed by a factor of two to three, spinach having the lowest value which would rather cause a lower $\mathrm{Cd}$ shoot concentration in contrast to what actually was found. The relative shoot growth rate $\left(R G R_{S}\right)$ varied by a factor of maximum of 1.7 . In contrast, the Cd shoot influx varied by a factor of up to 37 . It was mostly the $\mathrm{Cd}$ influx that determined the different $\mathrm{Cd}$ concentration in the shoot. Spinach had the highest $\mathrm{Cd}$ influx and the highest $\mathrm{Cd}$ shoot concentration and maize had the lowest $\mathrm{Cd}$ influx and the lowest shoot $\mathrm{Cd}$ concentration.

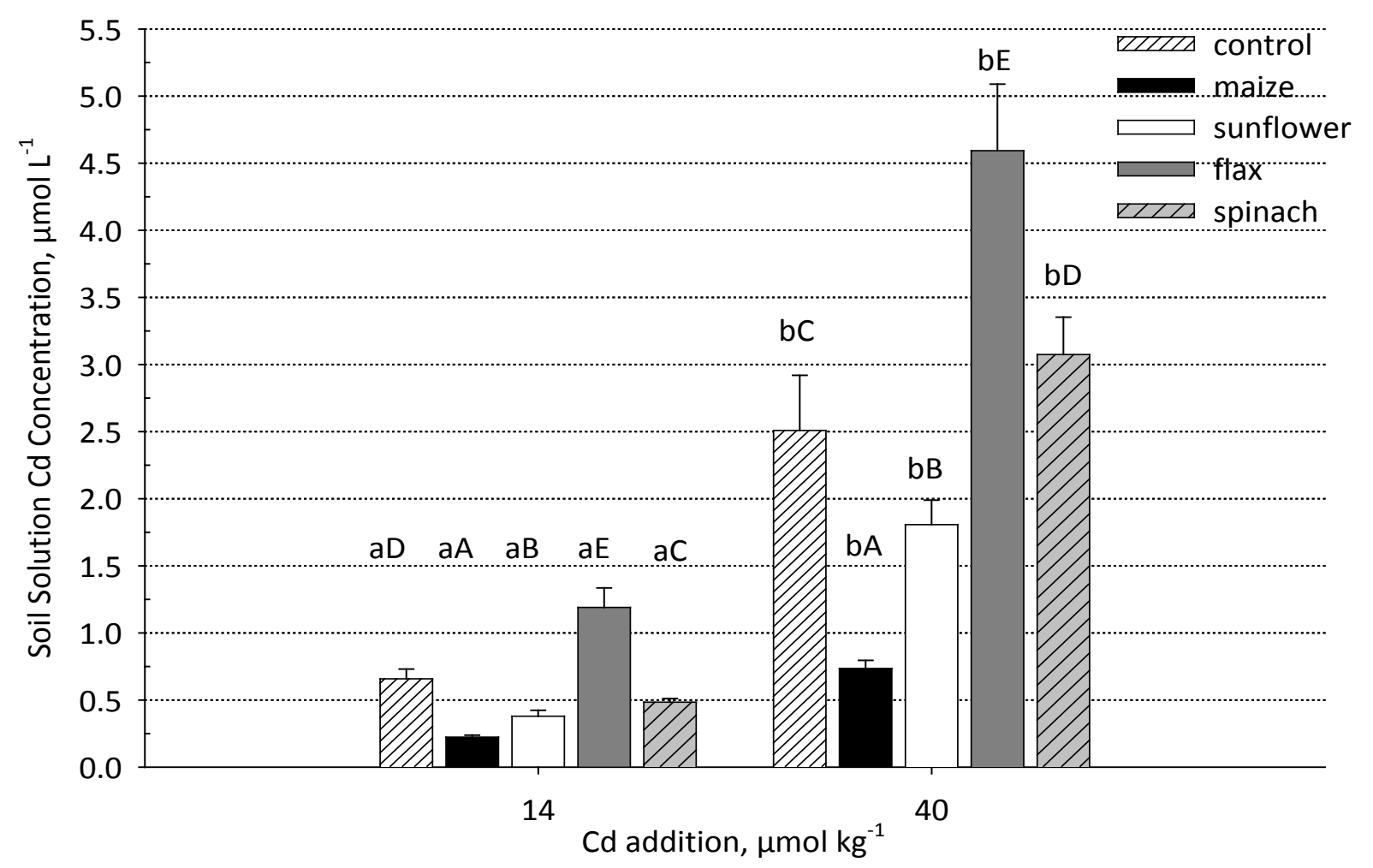

Figure 2-3 Cadmium in soil solution at different $\mathrm{Cd}$ addition to the soil (average between $1^{\text {st }}$ and $2^{\text {nd }}$ harvest). Different upper case letters show significant differences among plants at the same $\mathrm{Cd}$ addition. Different lower case letters show significant differences of the same plant at different $\mathrm{Cd}$ additions ( $\mathrm{p} \leq 0.05$; Student-Newmann-Keuls method). 
In order to investigate whether the activity of the roots changed the Cd availability in soil that might explain the different $\mathrm{Cd}$ influx shown before. The $\mathrm{Cd}$ concentration in soil solution after different plants had grown in the soil is shown in Fig. 2-3. The soil solution concentration varied somewhat from first to second harvest, either decreasing or also increasing (see Tab. 8-3 Appendix), therefore the average $\mathrm{Cd}$ concentration of the two harvests is shown in Fig. 2-3 and Fig. 2-4. The concentrations of $\mathrm{Cd}$ in the unplanted soil (control) increased almost linearly with increasing $\mathrm{Cd}$ addition. Plant growth changed $\mathrm{Cd}$ concentration in soil solution. The $\mathrm{Cd}$ concentration in soil solution significantly decreased after the growth of maize, sunflower, and spinach at the low $\mathrm{Cd}$ addition. For example, $\mathrm{Cd}$ concentration was decreased by about $65 \%$ after the growth of maize and by about $41 \%$ after the growth of sunflower compared to the control. The soil solution concentration of Cd was significantly higher (84\%) than the control after the growth of flax in the soil of $14 \mu \mathrm{mol} \mathrm{Cd} \mathrm{kg}{ }^{-1}$. At the high $\mathrm{Cd}$ addition $(40 \mu \mathrm{mol}$ $\mathrm{Cd} \mathrm{kg}^{-1}$ ) also spinach increased $\mathrm{Cd}$ soil solution concentration but much less than flax.

To investigate whether these changes in $\mathrm{Cd}$ solution concentration may explain the different $\mathrm{Cd}$ influx, the shoot $\mathrm{Cd}$ influx was plotted against average $\mathrm{Cd}$ concentration in soil solution between first and second harvest (Fig. 2-4). For all plants the relationship was about linear. It can be seen that maize, sunflower and flax adjusted to about the same line (slope around $2.5 \times 10^{-7} \mathrm{~cm} \mathrm{~s}^{-1}$ ) while spinach showed a clearly, 5 times, higher slope of $13.6 \times 10^{-7} \mathrm{~cm} \mathrm{~s}^{-1}$. For maize and sunflower, the $\mathrm{Cd}$ concentration range was up to $2 \mu \mathrm{M} \mathrm{Cd}$ while for flax and spinach it reached $5 \mu \mathrm{M} C d$ in the soil solution (see inset). 


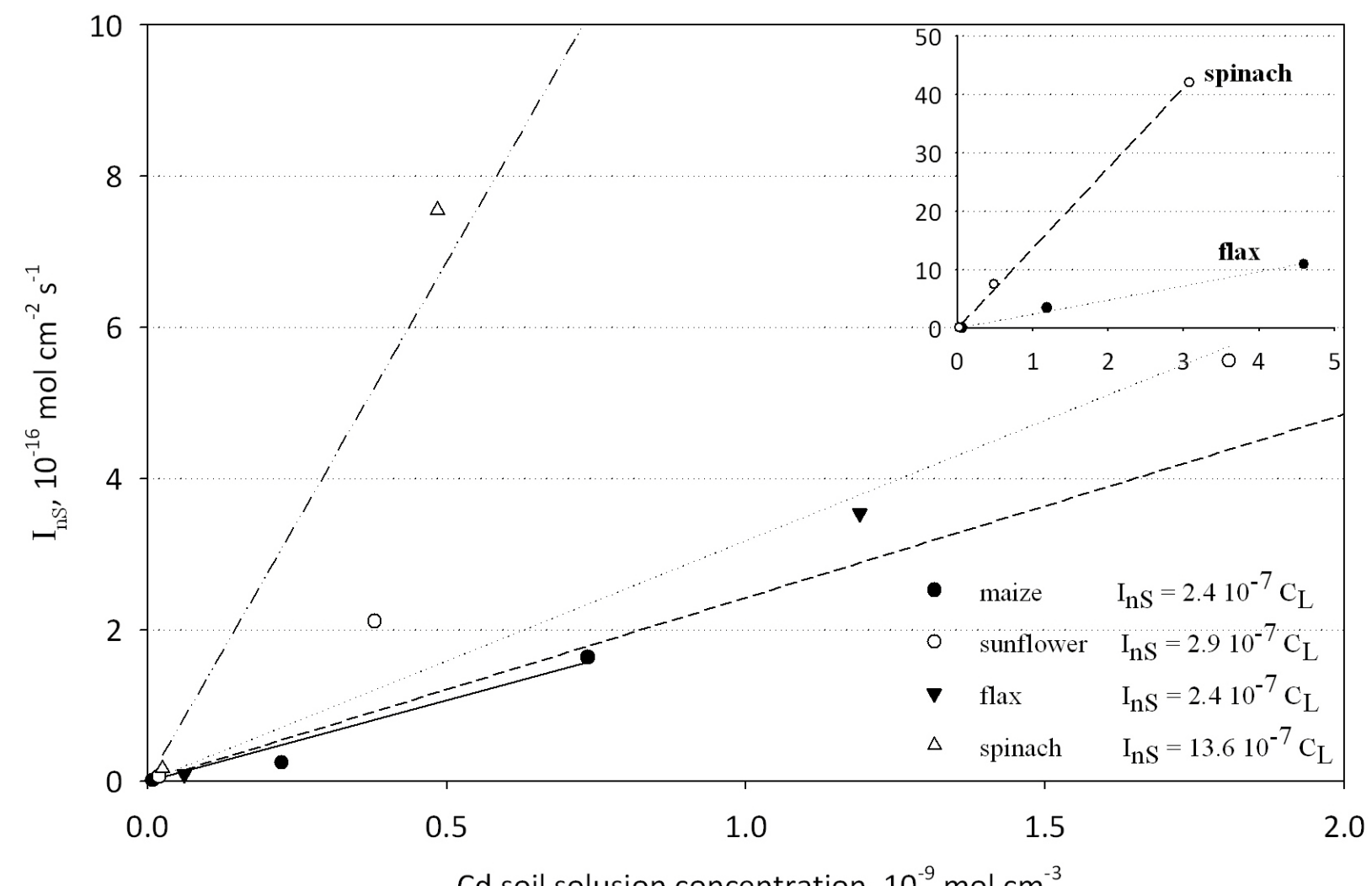

Figure 2-4 Shoot $\mathrm{Cd}$ influx against average $\mathrm{Cd}$ concentration in soil solution between first and second harvest after $\mathrm{Cd}$ addition.

\subsection{Discussion}

In the current experiment, we compared $\mathrm{Cd}$ accumulation and sensitivity or tolerance of the four plant species, maize (Gramineae), sunflower (Asteraceae), flax (Linaceae) and spinach (Chenopodiaceae) in order to find out possible factors and processes responsible for differences in shoot $\mathrm{Cd}$ accumulation when grown in the same soil.

The $\mathrm{Cd}$ concentration in soil solution without $\mathrm{Cd}$ contamination was $0.04 \mu \mathrm{M}$, which is low and found as tolerable for healthy growth of plants. The addition of $14 \mu \mathrm{mol} \mathrm{kg}{ }^{-1} \mathrm{Cd}$ to the soil did not inhibit, but slightly stimulated plant growth. $\mathrm{Wu}$ 


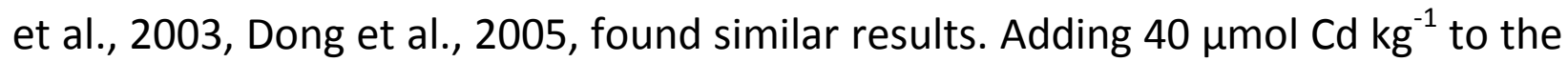
soil caused an inhibition of growth in flax and spinach only, indicating that they are $\mathrm{Cd}$ sensitive while the $\mathrm{Cd}$ tolerant plants (maize and sunflower) had a SDW of almost $100 \%$. Kloke and Schenke (1979) classified spinach also as Cd sensitive. The sensitivity of flax and spinach to soil Cd was confirmed by severe Cd toxicity symptoms. Similar toxicity symptoms reported Dong et al. (2005), in tomato, Salt et al. (1995) in mustard. The symptoms may be related to that $\mathrm{Cd}$ exerts a direct toxic effect, perhaps by affecting the process of photosynthesis or the activity of various enzymes (Weigel et al., 1980; Uraguchi et al., 2006), by reducing the chlorophyll content and/or transpiration (Haag-Kerwer et al.,1999; Vassilev et al. 2002; Hassan et al., 2005). The addition of $40 \mu \mathrm{mol} \mathrm{Cd} \mathrm{kg}^{-1}$ soil was clearly toxic to flax and spinach but not to maize and sunflower. Different tolerance to soil Cd has often been associated to two different strategies, i.e. exclusion and accumulation (Baker et al 2000, Yang et al., 2004). In our case the different tolerance among species to soil $\mathrm{Cd}$ is clearly related to the different $\mathrm{Cd}$ accumulation in the shoot.

We used equation 2-5 to quantify the factors responsible for different $\mathrm{Cd}$ accumulation in the shoot. The proportion of Cd translocated to shoot (Tab. 2-1) varied in the low $(14 \mu \mathrm{mol} \mathrm{Cd} \mathrm{kg})$ and high $\left(40 \mu \mathrm{mol} \mathrm{Cd} \mathrm{kg}^{-1}\right)$ addition from $60 \%$ to $70 \%$ in the less sensitive species and from $70 \%$ to $85 \%$ in the more sensitive species. Spinach the most sensitive species always showed the highest translocation rate. However, the variation of $60 \%$ to $85 \%$ could not explain the variation of shoot $\mathrm{Cd}$ concentration by a factor of about 10 to 30 . Similarly, the variation of the root-shoot ration and the relative shoot growth rate was low and could not explain the variation in shoot Cd concentration (Tab. 2-3). 
Only the $\mathrm{Cd}$ net influx varied parallel to the shoot $\mathrm{Cd}$ concentration, i.e. the $\mathrm{Cd}$ influx was the major factor responsible for the different $\mathrm{Cd}$ accumulation in the shoot. Why this differences in Cd influx?

A possible mechanism for different $\mathrm{Cd}$ influx among plants may be because plants can affect the $\mathrm{Cd}$ availability in soil. Padeken (1998) found that the $\mathrm{CaCl}_{2}$ extractable soil Cd varied among plants by a factor of two. Instead of using a Cd extraction like Padeken (1998) we used the $\mathrm{Cd}$ concentration in soil solution, because $\mathrm{Cd}$ influx depends on $\mathrm{Cd}$ concentration in soil solution at the root surface and also $\mathrm{Cd}$ transport to the root is in the soil solution. In fact, plants had a strong effect on $\mathrm{Cd}$ concentration in soil solution, i.e. plant growth decreased as well as increased $\mathrm{Cd}$ concentration in soil solution (Fig. 2-3). The decrease of $\mathrm{Cd}$ in soil solution at low $\mathrm{Cd}$ addition was not related to $\mathrm{Cd}$ uptake by the plants, since maize with the lowest amount of Cd removed from soil (about $0.15 \mu \mathrm{mol} \mathrm{kg}{ }^{-1}$ ) showed the strongest decrease of $\mathrm{Cd}$ in soil solution. Whereas spinach with the highest amount of $\mathrm{Cd}$ removed, (about $1.4 \mu \mathrm{mol} \mathrm{kg}{ }^{-1}$ ) showed the least decrease of $\mathrm{Cd}$ in soil solution. This indicates that root activity of maize caused a $\mathrm{Cd}$ immobilization in soil. Egle (2002) observed similar immobilization of $\mathrm{Cd}$ for several lupine genotypes and for Lolium multiflorum. Morel et al. (1986) have shown that mucilage, a high-molecular weight exudate, of maize rhizosphere are composed mainly of polysaccharidic and contain proteins (4\%) and a high proportion of uronic acids (34\%) was able to bind $\mathrm{Cd}$. This high binding ability of mucilage of maize could explain the $\mathrm{Cd}$ immobilization in soil. Furthermore, it might be stressed that the composition of root exudates probably depends on the nutrient status of the plants and Cd stress condition (Keller, 2000; Egle, 2002). 
In contrast to decreasing $\mathrm{Cd}$ soil solution concentration flax at both $\mathrm{Cd}$ levels and spinach at the high $\mathrm{Cd}$ level increased $\mathrm{Cd}$ soil solution concentration. This situation can occur when plants solubilize more $\mathrm{Cd}$ as is taken up by them. The $\mathrm{Cd}$ solubility in soil may be affected by chemical action of root exudates or microbial activity in the rhizosphere that increase $\mathrm{Cd}$ concentration in soil solution $(0.68 \mu \mathrm{M}$ to $1.2 \mu \mathrm{M})$. The differences in $\mathrm{Cd}$ concentration in soil solution could be the result of the plants response to varying soil $\mathrm{Cd}$ levels possibly affecting soil particle surface. Cieslinski et al. (1998) reported differences in total low-molecular-weight organic acids detected in the rhizosphere soil of durum wheat species that was related to $\mathrm{NH}_{4} \mathrm{Cl}$ extractable $\mathrm{Cd}$ indicating differences in rhizosphere dynamics, uptake and $\mathrm{Cd}$ distribution within plants. Furthermore, plant roots contain many organic anions varying in chain length with lactate, acetate, oxalate, succinate, fumarate, malate, citrate, isocitrate, and aconitate being the main components and potential metal chelators (Jones, 1998; Marschner, 1995). These differences in composition of exudates could influence the rhizospere, with both an increase or decrease in the Cd activity may be present in the rhizosphere (Mench and Martin, 1991; Egle 2002).

In order to test whether the changes of $\mathrm{Cd}$ concentration in soil solution can explain the different $\mathrm{Cd}$ influx among plants we plotted the $\mathrm{Cd}$ influx against average $\mathrm{Cd}$ concentration in soil solution after growing the plants (Fig. 2-4). Comparing maize, sunflower and flax the changes of $\mathrm{Cd}$ soil solution concentration could to a large extent explain the differences of $\mathrm{Cd}$ influx observed, i.e. they laid on about the same line and if flax had a larger $\mathrm{Cd}$ influx than sunflower and maize it was because it increased $\mathrm{C}_{\mathrm{Li}}$ the strongest. In contrast, spinach differs from these three plant species in that at the same $\mathrm{Cd}$ concentration in soil solution it 
had a $\mathrm{Cd}$ influx about 5 times higher. This different behavior of spinach may be related to spinach having a higher root absorbing power, i.e. at the same concentration at the root surface, $\mathrm{Cd}$ influx is higher. To our knowledge, there are no data of root absorbing power of plants in the concentration range we found in soil solution. It also may be related to that in the case of the other plants (maize, sunflower and flax) part of the $\mathrm{Cd}$ in soil solution may be present as chelates. Chelated ions are usually not available for adsorption by roots (Senden et al., 1995). This agrees with the findings of Cabrera et al. (1988) who found that humic acid lowered Cd uptake of barley plants (Gramineae) grown in hydroponic solutions containing $\mathrm{Cd}$ concentrations (0.5-5 mg L${ }^{-1}$ ) and humic acid (190-1710 $\left.\mathrm{mg} \mathrm{L}^{-1}\right)$.

In summary, the results show that shoot $\mathrm{Cd}$ concentration was very different among the plant species which was mainly related to the $\mathrm{Cd}$ influx, which in the same soil differed by a factor of 30 while the size root system and shoot growth rate had a little effect. Plants affected $\mathrm{Cd}$ availability in soil, in some cases decreasing in other cases increasing $\mathrm{C}_{\mathrm{Li}}$ i.e. plants immobilized or solubilized $\mathrm{Cd}$. However, these changes in $\mathrm{C}_{\mathrm{Li}}$ were not enough to explain differences in $\mathrm{Cd}$ influx.

We hypothesize that plant species furthermore differ in their root absorbing power and that possibly part of $\mathrm{Cd}$ in soil solution is present as a complex, which is not available for uptake by the roots. In order to validate the findings in soil experiment will need to be investigated further by comparing the results of an experiment with nutrient solution (Stritsis 2005), in which he had found the relationship between the $\mathrm{Cd}$ influx and $\mathrm{Cd}$ concentration at the root surface (i.e. root absorbing power). The comparison will be performed in the next chapter 
using a mechanistic model (NST 3.0) of Cd uptake from the soil to find further explanations for the differences in Cd influx. 


\section{Mechanistic Simulation and Measured CADMIUM UPTAKE FROM SOIL}

\subsection{Indroduction}

Cadmium uptake and $\mathrm{Cd}$ shoot concentration differed strongly among species. These differences were mainly due to different influx that varied among them by a factor of up to 30, even though the plants had been grown in the same soil (Chap. 2). The $\mathrm{Cd}$ influx depends on $\mathrm{Cd}$ transport in the soil and on uptake physiology of the plants. It could be shown that the $\mathrm{Cd}$ concentration in soil solution, $\mathrm{C}_{\mathrm{Li}}$, as important parameter of $\mathrm{Cd}$ transport in the soil and of uptake into the plant was different among plant species (Chap. 2). However, this did not totally explain the observed differences in their Cd influx. In this chapter, further explanations will be sought by using mechanistic modeling of $\mathrm{Cd}$ uptake from soil as will be explained below.

For the last 50 years, the processes governing the ion transfer from soil into the root have been investigated. They are the transport from soil to the root surface by mass flow $\left(F_{M}\right)$ and diffusion $\left(F_{D}\right)$ (Barber, 1962) and the uptake into the root, which depends on the ion concentration in the soil solution at the root surface. The latter usually follows a saturation curve that can be described by a MichaelisMenten function (Epstein, 1972). The transport by mass flow depends on the concentration in soil solution and the water flow towards the root. Diffusion depends on soil parameters like moisture content and buffer power, but is driven by the concentration gradient from bulk soil to root surface. This gradient is 
established by plant uptake and depends therefore, on uptake kinetics. Hence, ion uptake from soil is the result of an interaction of soil and plant processes and factors. Mathematical models have been used to simulate these interacting processes (Nye and Marriott, 1969; Claassen and Barber, 1976; Barber and Cushmann, 1981; Claassen and Steingrobe, 1999). These models calculate an ion uptake based on soil and plant parameters, which are independent of the measured uptake it self. The models have mainly been used to describe $\mathrm{P}$ or $\mathrm{K}$ uptake from soil. In some cases, these models calculated similar results as observed, for example, Seiffert et al. (1995) clearly described the K uptake of maize at different soil bulk density and water content. Such results show that the models are able to describe soil transport and uptake. However, simulated $P$ uptake of wheat and sugar beet growing in low $P$ soils was often underestimated (Bhadoria et al., 2002). This shows that uptake conditions might be more complex that can be descried by mass flow, diffusion, and Michaelis-Menten kinetics or that the estimation of soil and plant parameters was not adequate. A sensitivity analysis for example indicated that most likely plants may have increased $\mathrm{P}$ soil solution concentration, i.e. they mobilized soil $\mathrm{P}$, whereas changes of uptake kinetic parameters were of low effect (Bhadoria et al., 2002).

The objective of this research was to use a mechanistic model to describe the $\mathrm{Cd}$ influx of maize, sunflower, flax and spinach and to use a sensitivity analysis not only on soil but also on plant parameters in order to find possible reasons for differences of Cd influx observed among plant species. 


\subsection{Materials und Methods}

The model NST 3.0 (Claassen 1990; Claassen and Steingrobe, 1999) calculates soil transport of nutrients towards the root by diffusion and mass flow taking sorption processes to the soil matrix into account. The uptake into the root is assumed to follow Michaelis-Menten kinetics. The model was run to simulate the Cd uptake from soil described in Chap.2. The soil parameters and some plant parameters were taken from that same experiment and uptake kinetic parameters were from earlier nutrient solution experiment (Stritsis, 2005). Calculations were performed for the time period between day 28 (harvest I) and 43 (harvest II) after germination.

\section{Soil parameters}

$\mathbf{D}_{\mathrm{L}}$ : Diffusion coefficient in water $\left(7.2 \times 10^{-6} \mathrm{~cm}^{2} \mathrm{~s}^{-1}\right)$ obtained from Parsons (1959)

๑: Volumetric soil water content, was obtained form gravimetric water content times soil bulk density $\left(\mathrm{cm}^{3} \mathrm{~cm}^{-3}\right)$

f: The impedance factor which depends on $\Theta$. It was calculated according to Barraclough and Tinker (1981); $f=1.58 \times \theta-0.17$

$\mathrm{C}_{\mathrm{Li}}$ : Initial $\mathrm{Cd}$ soil solution concentration, measured in unplanted and planted pots at day 28 ( $\mu \mathrm{mol} \mathrm{L} \mathrm{L}^{-1}$ solution)

b: buffer power, assuming a linear buffer curve, b was calculated form $\mathrm{Cd}$ added ( $\mu \mathrm{mol} \mathrm{L}{ }^{-1}$ soil) to the soil divided by $\mathrm{C}_{\mathrm{L}}$ ( $\mu \mathrm{mol} \mathrm{L^{-1 }}$ solution)

\section{Plant parameters}

$r_{0}:$ root radius, $(\mathrm{cm})$ 
$\mathbf{r}_{1}$ : Half-distance among neighboring roots, $(\mathrm{cm})$

k: Relative root growth rate, $\left(\mathrm{d}^{-1}\right)$

$\mathrm{L}_{0}$ : Root length at first harvest, $(\mathrm{cm})$

\section{Uptake kinetic parameters}

The uptake kinetics describes the relationship between the net influx, $I_{\mathrm{n}}\left(\mathrm{mol} \mathrm{cm} \mathrm{cm}^{-1}\right)$, and the concentration at the root surface, $\mathrm{C}_{\mathrm{L} 0}$. For $\mathrm{Cd}$ in the low concentration range, as used in this study, this relationship is linear (Stritsis, 2005) of the form

$$
I_{n}=\alpha \cdot C_{L O}
$$

$\alpha\left(\mathrm{cm} \mathrm{s}^{-1}\right)$ being called the root absorbing power (Nye and Tinker, 1977)

The NST 3.0 simulation model uses the saturation kinetics of Michaelis-Menten

$$
I_{n}=\frac{I_{\max } \cdot C_{L O}}{K_{m}+C_{L O}}
$$

$I_{\max }$ is the maximum influx and $K_{m}$ is the Michaelis constant, i.e. the concentration at which $\mathrm{I}_{\mathrm{n}}=\mathrm{I}_{\max } / 2$

In the low concentration range, clearly below $\mathrm{K}_{\mathrm{m}}$, the uptake isotherm can be approximated by a straight line given by

$$
I_{n}=\frac{I_{\max }}{K_{m}} \cdot C_{L O}
$$

that means, $\alpha$ of equation 3-1 is given by $I_{\max } / K_{m}$. 
In this study $\alpha$ was known from studies in solution culture (Stritsis, 2005) and setting $\mathrm{K}_{\mathrm{m}}$ at $10 \mu \mathrm{M}$, i.e. clearly above the $\mathrm{Cd}$ concentration found in soil solution, $I_{\max }$ for model calculation is given as follows

$$
I_{\max }=\alpha \cdot K_{m}
$$

It has to be stated very clearly that $\mathrm{I}_{\max }$ and $\mathrm{K}_{\mathrm{m}}$ were not measured directly by fitting a Michaelis-Menten curve to the experimental data. The concentration range was very low, i.e. it was in the quasi-linear range of the Michaelis-Menten curve, not allowing a satisfying fitting. Therefore, $I_{\max }$ was derived from the $\alpha$ value under an assumption of a given $\mathrm{K}_{\mathrm{m}}$ value. The $\alpha$ values were taken from Stritsis (2005).

\subsection{Results}

The simulation of the Cd uptake was performed between two harvests, 28 and 43 days after germination. Cadmium uptake kinetics from the nutrient solution experiment together with other soil and plant parameters from the soil experiment were used to simulate $\mathrm{Cd}$ uptake from soil. The input parameters used in the model are summarized in Table 3-1 and were taken from experiment of Chap. 2, and the $\alpha$ values from Stritsis (2005).

Soil solution $\mathrm{Cd}$ concentration, $\mathrm{C}_{\mathrm{L}}$, was different among the plants even though they grew in the same soil. It varied by a factor of 6 because of the activity of the roots. According to changes of $\mathrm{C}_{\mathrm{Li}}$ also the buffer power, $\mathrm{b}$, changed. Value of root absorbing power, $\alpha$, varied by a factor of about 3. Spinach and flax had a similar and higher $\alpha$ value than maize and sunflower. To calculate the total $\mathrm{Cd}$ uptake of the growing root system, based on the uptake per $\mathrm{cm}$, the parameter $\mathrm{k}$ (relative 
growth constants) and $\mathrm{L}_{0}$ (initial root length at the first harvest) are needed. However, comparison between calculated and measured data will be done on the basis of influx.

Table 3-1 Parameters used for Cd-uptake model calculations

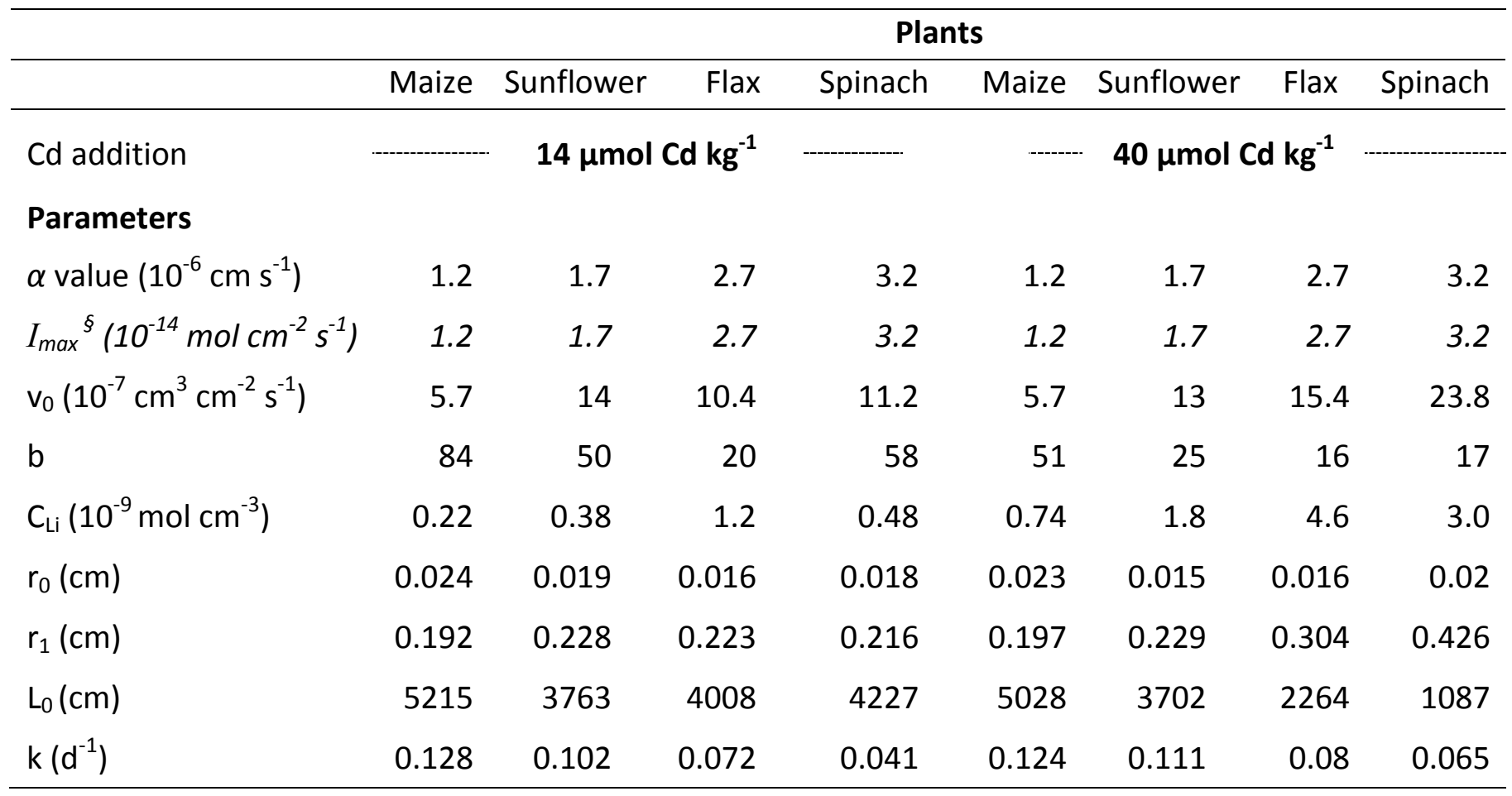

Parameter for all treatments: $D_{L}=7.2 \times 10^{-6} \mathrm{~cm}^{2} \mathrm{~s}^{-1}, K_{\mathrm{m}}=1 \times 10^{-8} \mathrm{~mol} \mathrm{~cm}^{-3}, C_{\min }=0 \mathrm{~mol} \mathrm{~cm}{ }^{-3}, \Theta=0.2 \mathrm{~cm}^{3} \mathrm{~cm}^{-3}$,

$f=0.15(f=1.58 \times \Theta-0.17),{ }^{\S} I_{\max }=\alpha \times K_{m}$

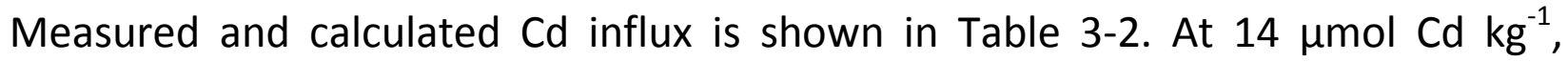
measured $\mathrm{Cd}$ influx was $0.25 \times 10^{-16} \mathrm{~mol} \mathrm{~cm}^{-2} \mathrm{~s}^{-1}$ for maize, which was 10 -fold lower than that of sunflower and 30-fold lower than that of spinach. Under high $\mathrm{Cd}$ addition, $\mathrm{Cd}$ influx of maize was 26 - fold lower than that of spinach. After calculation with NST 3.0, calculated Cd influx was $2.4 \times 10^{-16} \mathrm{~mol} \mathrm{~cm}^{-2} \mathrm{~s}^{-1}$ for maize, which was only 2 -fold lower than that of sunflower and 5-fold of spinach. Under high $\mathrm{Cd}$ addition, $\mathrm{Cd}$ influx of spinach was only 10- fold higher than that of maize. 
Comparing calculated and measured values, it can be seen that the calculated $\mathrm{Cd}$ influx does not agree with measured values. Under low $\mathrm{Cd}$ addition $\mathrm{Cd}$ influx for maize was overestimated 10 fold and for flax 7 fold whereas for spinach it was only 1.6. Under high $\mathrm{Cd}$ addition, the overestimation was lower for maize (4.7) and for sunflower (4.7) and for flax was similar to the low $\mathrm{Cd}$ addition. However, prediction was closer for spinach, being 1.6 under lower $\mathrm{Cd}$ addition and 1.8 under higher $\mathrm{Cd}$ addition of the measured influx.

Table 3-2 Calculated shoot influx in comparison to measured shoot influx of maize, sunflower, flax and spinach at different $\mathrm{Cd}$ addition to the soil.

\begin{tabular}{|c|c|c|c|}
\hline \multirow[t]{2}{*}{ Plant } & \multicolumn{3}{|c|}{$\begin{array}{c}\text { Influx } \\
10^{-16} \mathrm{~mol} \mathrm{~cm}^{-2} \mathrm{~s}^{-1}\end{array}$} \\
\hline & measured & calculated & Calc / Meas. \\
\hline & \multicolumn{3}{|c|}{$14 \mu \mathrm{mol} \mathrm{Cd} \mathrm{kg}$} \\
\hline Maize & 0.3 & 2.4 & 9.8 \\
\hline Sunflower & 2.1 & 5.3 & 2.5 \\
\hline Flax & 3.5 & 24.4 & 6.9 \\
\hline \multirow[t]{2}{*}{ Spinach } & 7.5 & 12.0 & 1.6 \\
\hline & \multicolumn{3}{|c|}{$40 \mu \mathrm{mol} \mathrm{Cd} \mathrm{kg}{ }^{-1}$} \\
\hline Maize & 1.6 & 7.7 & 4.7 \\
\hline Sunflower & 5.6 & 25.9 & 4.7 \\
\hline Flax & 11.0 & 82.2 & 7.5 \\
\hline Spinach & 42.1 & 75.0 & 1.8 \\
\hline
\end{tabular}

A sensitivity analysis will help to find possible reasons for the overestimation of $\mathrm{Cd}$ influx. In the sensitivity analysis, reduced values of the initial solution $\mathrm{Cd}$ concentration and root absorbing power were used. A sensitivity analysis in soil buffer power is not shown because there was almost no effect. 
Figure 3-1 shows the influence of the change ratio of $\mathrm{C}_{\mathrm{Li}}$ on calculated $\mathrm{Cd}$ influx at $14 \mu \mathrm{mol} \mathrm{Cd} \mathrm{kg}{ }^{-1}$. It can be seen that the relationship between $\mathrm{C}_{\mathrm{Li}}$ and calculated $\mathrm{Cd}$ influx was almost linear. The figure also shows the point of the change ratio at which the calculated $\mathrm{Cd}$ influx is equal to measured value. For sunflower, the calculated $\mathrm{Cd}$ influx was similar to measured $\mathrm{Cd}$ influx when $\mathrm{C}_{\mathrm{Li}}$ was reduced to $35 \%$ while for flax the reduction was to $15 \%$ (Fig. 3-1). A decrease in $C_{\mathrm{Li}}$ to $63 \%$ resulted in $100 \%$ prediction by the model for spinach. For maize, the sensitivity analysis for $\mathrm{C}_{\mathrm{Li}}$ showed that the change ration should be close to $10 \%$ to get $100 \%$ prediction by the model.

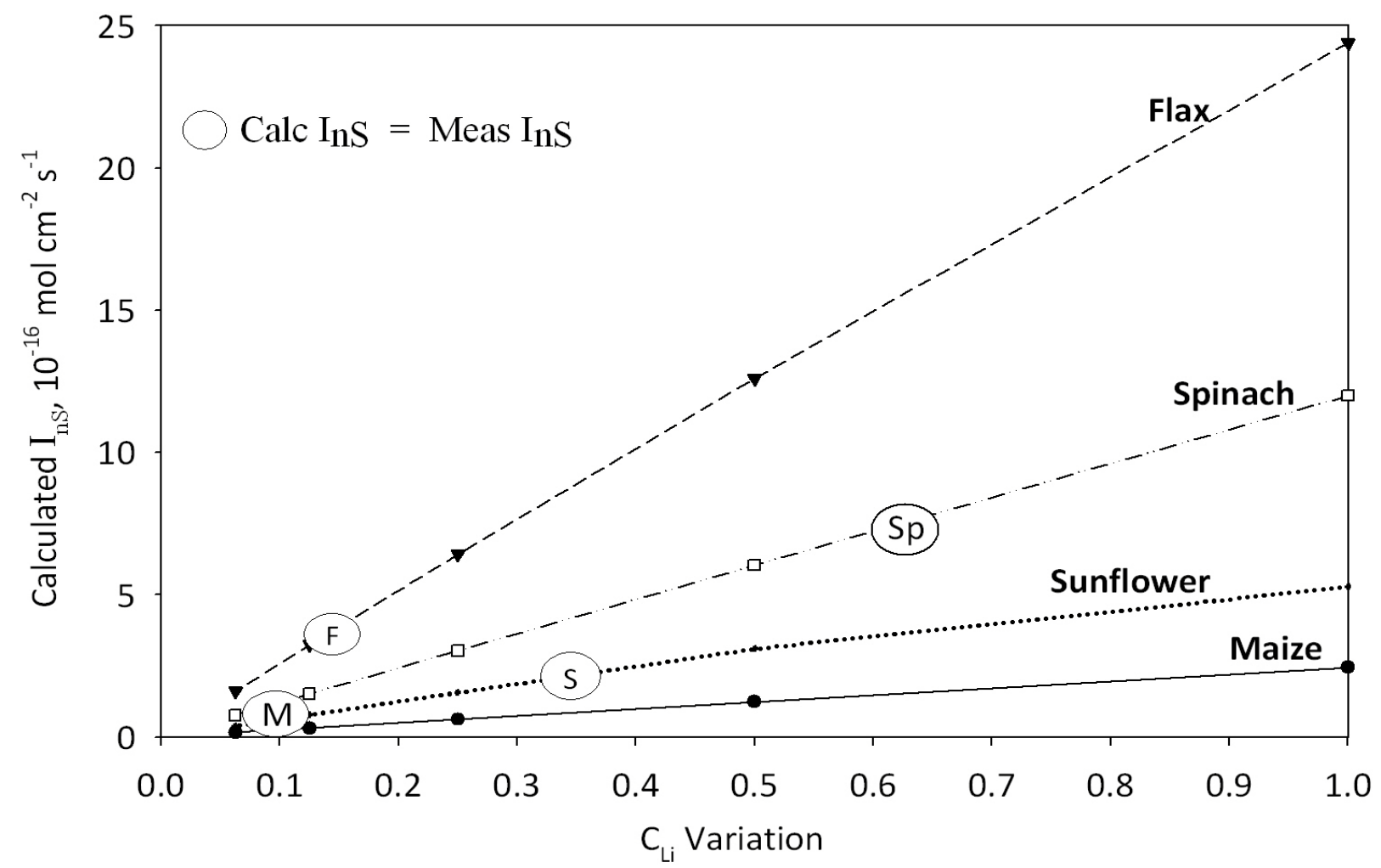

Figure 3-1 Sensitivity analysis. Response of calculated influx to changes in the initial soil solution concentration $\left(\mathrm{C}_{\mathrm{Li}}\right)$. Initial data set of the treatment with an application of $14 \mu \mathrm{mol} C \mathrm{Cd}$ $\mathrm{kg}^{-1}$. M: maize, S: sunflower, F: flax, Sp: spinach. Circle with letter indicates at which change ration calculated influx is equal to measured influx 
Table 3-3 summarizes the sensitivity analysis of varying $\mathrm{C}_{\mathrm{Li}}$ as well as $\alpha$ at both $\mathrm{Cd}$ levels for all plants. The values shown in the first line of Table 3-3 are the results shown in Fig. 3-1.

The table gives the change needed of the soil solution concentration $\left(\mathrm{C}_{\mathrm{Li}}\right)$ and the root absorbing power $(\alpha)$ so that the calculated shoot influx is equal to the measured shoot influx. The sensitivity analysis for $\mathrm{C}_{\mathrm{Li}}$ and $\alpha$ value show that by decreasing their values, change ratio $<1$, simulated $\mathrm{Cd}$ influx could become $100 \%$ prediction of measured $\mathrm{Cd}$ influx. $\mathrm{A}$ decrease in $\mathrm{C}_{\mathrm{Li}}$ by $90 \%$ (change ratio $=0.1$ ) resulted in $100 \%$ prediction by the model for maize at $14 \mu \mathrm{mol} \mathrm{Cd} \mathrm{kg}{ }^{-1}$ addition in soil while at $40 \mu \mathrm{mol} \mathrm{kg}{ }^{-1}$ the decrease needed was $80 \%$. The effect of changing $\alpha$ value was similar to changing $\mathrm{C}_{\mathrm{Li}}$.

Table 3-3 The values are the factors (change factor) by which the original $\mathrm{Cd}$ soil solution concentration, $\mathrm{C}_{\mathrm{Li}}$, or the root absorbing power, $\alpha$, had to be changed so that the calculated influx became equal to the measured $\mathrm{Cd}$ influx.

\begin{tabular}{|c|c|c|c|c|c|}
\hline $\mathrm{Cd}$ add & Parameter & Maize & Sunflower & Flax & Spinach \\
\hline$\mu \mathrm{mol} \mathrm{kg}{ }^{-1}$ & & \multicolumn{4}{|c|}{ change ratio } \\
\hline 14 & $\mathrm{C}_{\mathrm{Li}}$ & 0.10 & 0.33 & 0.15 & 0.63 \\
\hline 14 & $\alpha$ & 0.10 & 0.31 & 0.11 & 0.54 \\
\hline 40 & $C_{L i}$ & 0.21 & 0.21 & 0.11 & 0.53 \\
\hline 40 & $\alpha$ & 0.21 & 0.21 & 0.11 & 0.49 \\
\hline
\end{tabular}

To get a better understanding of the $\mathrm{Cd}$ dynamics in the rhizosphere and to get possible explanation for the results of the sensitivity analysis of $\mathrm{C}_{\mathrm{Li}}$ and $\alpha$ the calculated concentration profiles around roots were studied.

Some examples are shown in Fig. 3-2 and Fig. 3-3 for the treatment of $14 \mu \mathrm{mol}$ $\mathrm{kg}^{-1} \mathrm{Cd}$ addition, for one with the original values of $\mathrm{C}_{\mathrm{Li}}$ and $\alpha$ and for another with 
the values for $\mathrm{C}_{\mathrm{Li}}$ or $\alpha$ where the calculated $\mathrm{Cd}$ influx became equal to the measured $\mathrm{Cd}$ influx. Figure 3-2A shows for maize that the initial $\mathrm{Cd}$ concentration of $0.22 \mu \mathrm{M}$ was decreased at the root surface to only $0.19 \mu \mathrm{M}$ after $14 \mathrm{~d}$ of uptake and even so the calculated $\mathrm{Cd}$ influx was 10 times higher $\left(2.4 \times 10^{-16} \mathrm{~mol} \mathrm{~cm}^{-2} \mathrm{~s}^{-1}\right)$ than the measured $\mathrm{Cd}$ influx $\left(0.25 \times 10^{-16} \mathrm{~mol} \mathrm{~cm}^{-2} \mathrm{~s}^{-1}\right)$. For spinach (Fig 3-3A), the initial $\mathrm{Cd}$ concentration of $0.48 \mu \mathrm{M}$ was decreased at the root surface to $0.36 \mu \mathrm{M}$ after $14 \mathrm{~d}$ of uptake. In addition, here the calculated Cd influx was higher but only 1.6 fold higher than the measured Cd influx.

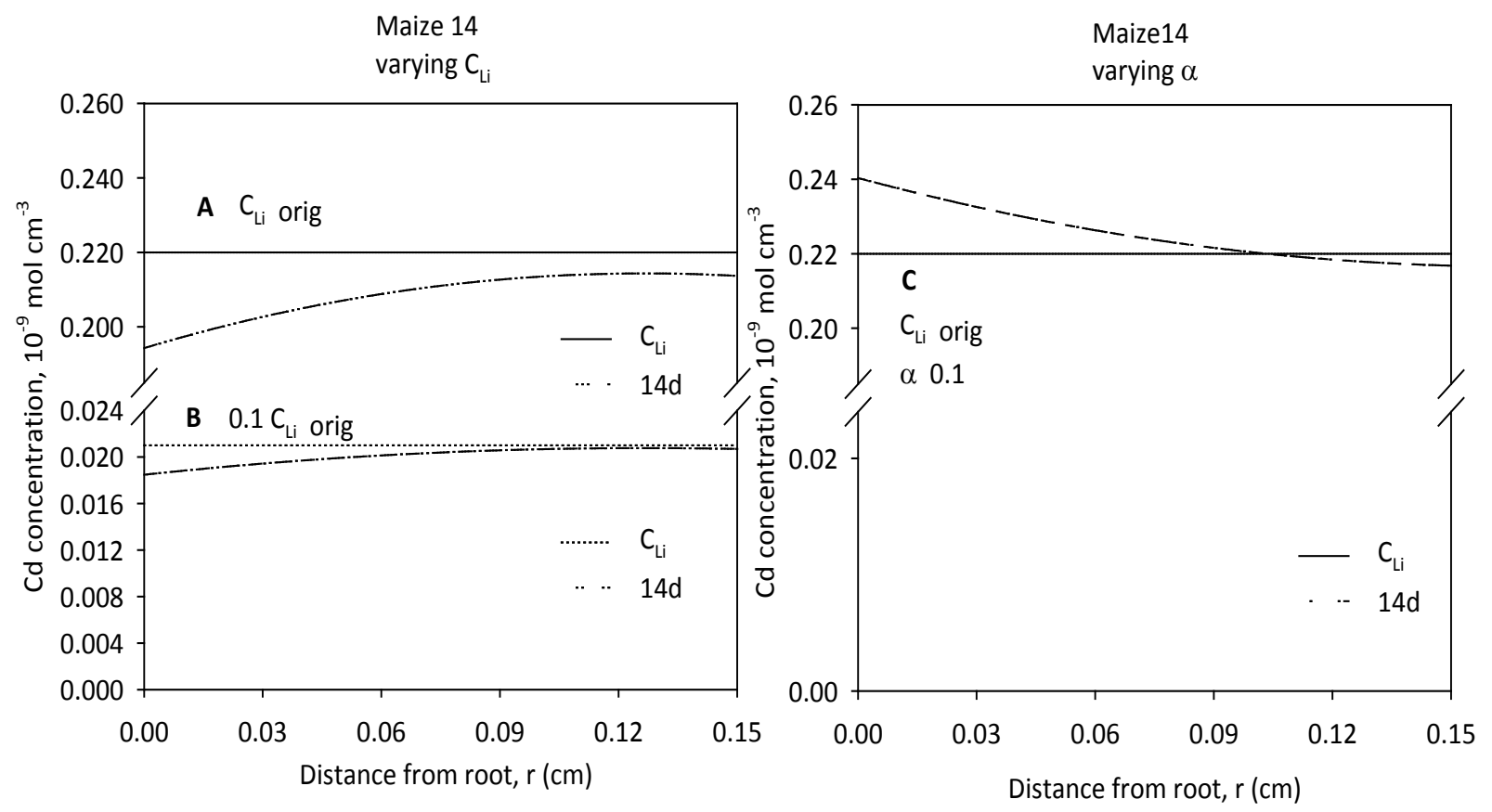

Figure 3-2 Calculated depletion of $\mathrm{Cd}$ from the rhizosphere of maize after 14 days of

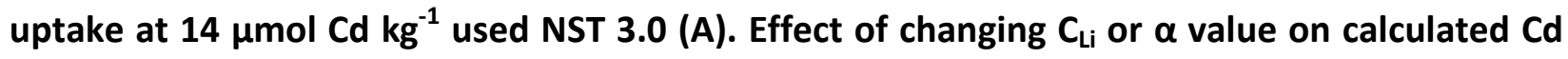
depletion in the rhizosphere of maize (B\&C).

The results of model calculations showed an overestimation of the $\mathrm{Cd}$ influx. Therefore, a sensitivity analysis was conducted by incrementally changing the values of initial solution $\mathrm{Cd}$ concentration $\left(\mathrm{C}_{\mathrm{Li}}\right)$ to find the reason for overestimation of Cd influx (Table 3-2). 

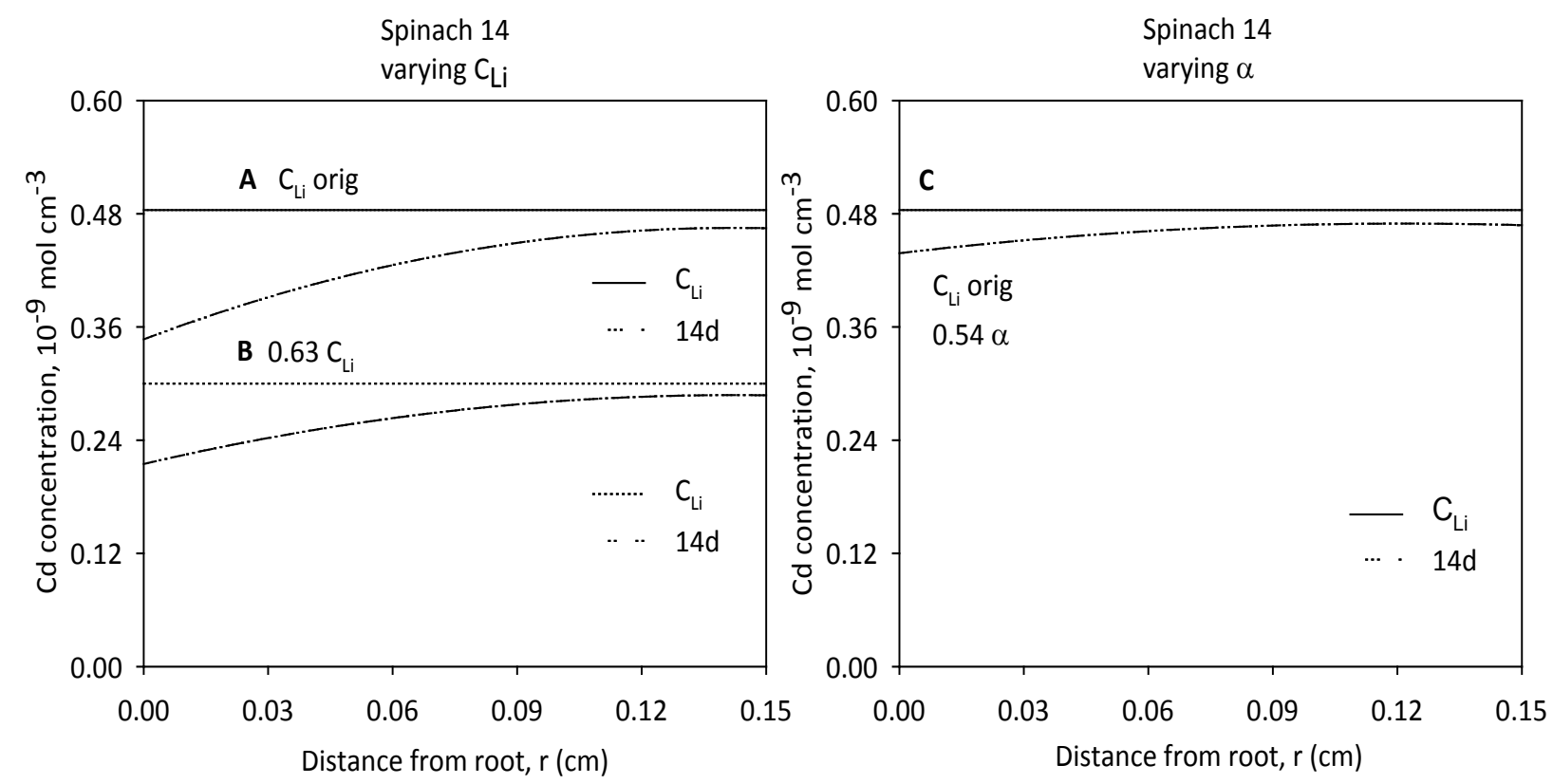

Figure 3-3 Calculated depletion of $\mathrm{Cd}$ from the rhizosphere of spinach after 14 days of

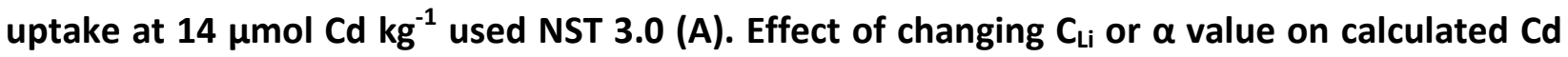
depletion in the rhizosphere of spinach (B\&C).

The sensitivity analysis for $\mathrm{C}_{\mathrm{Li}}$ had shown that by decreasing the value down to $10 \%$ of the original value got $100 \%$ prediction of measured $\mathrm{Cd}$ influx of maize (Fig. 3-2B) and the $\mathrm{C}_{\mathrm{Li}}$ decreased only by $0.012 \mu \mathrm{M}$. For spinach (Fig. 3-3B), the same was achieved by decreasing $\mathrm{C}_{\mathrm{Li}}$ down to $63 \%$ of the original vaule and according to the model calculations, decreased solution $\mathrm{Cd}$ concentration at the root surface to $0.22 \mu \mathrm{M}$ as compared to $0.019 \mu \mathrm{M}$ for maize after 14 days of uptake.

On the other hand, when decreasing the root absorbing power ( $\alpha$ value) of maize down to $10 \%$ of the original value caused an increased $\mathrm{Cd}$ concentration at the root surface from $0.22 \mu \mathrm{M}$ to $0.24 \mu \mathrm{M}$ (Fig. 3-2C). For spinach, calculated Cd influx was equal to measured $\mathrm{Cd}$ influx after decreasing the root absorbing power down to $54 \%$ but in contrast to maize the $\mathrm{Cd}$ concentration at the root surface decreased from $0.48 \mu \mathrm{M}$ to $0.46 \mu \mathrm{M}$ (Fig. 3-3C). 


\subsection{Discussion}

Uptake-kinetic parameters from the nutrient solution experiment (Stritsis, 2005), together with soil Cd parameters (Tab. 3-1), were used in the NST 3.0 model. The model will help to understand why plants differ in their $\mathrm{Cd}$ accumulation because besides the calculated $\mathrm{Cd}$ uptake by plants, the $\mathrm{Cd}$ dynamics in the rhizosphere is calculated. Therefore, it will be possible, for example, to recognize to which extent different species lower the $\mathrm{Cd}$ concentration in the rhizosphere.

Before (Chap. 2) had shown differences in $\mathrm{Cd}$ uptake among the plant species mainly based on differences in their $\mathrm{Cd}$ influx. Changes of $\mathrm{C}_{\mathrm{Li}}$ caused by the plants did not explain the lower $\mathrm{Cd}$ influx of maize and higher $\mathrm{Cd}$ influx of spinach. In this chapter, besides changes of $\mathrm{C}_{\mathrm{Li}}$ caused by the roots we also included uptake properties of the root and used model calculation based on mechanisms of ion transport in soil and uptake kinetics of the root. Even though the model used is more comprehensive than considering just single factors, it was not able to describe the different $\mathrm{Cd}$ influx of the plant species, i.e. for one it overestimated the $\mathrm{Cd}$ influx up to 10 times and for another it was also not able to explain the differences of Cd influx observed among plant species.

These results are in contrast with results concerning major nutrients mainly $\mathrm{K}$ (Seiffert et al., 1995; El Dessouri, 2002) or P (Bhadoria 2002) where similar model calculation showed agreement between calculated and measured values or underestimated them even strongly. For other essential heavy metals such as $\mathrm{Mn}$ has been reported by Sadana et al. (2005) that the calculated Mn influx in different wheat cultivars and in low Mn soil concentration (below $1 \mu \mathrm{M}$ ) reached only to $55 \%-74 \%$ of the measured values. 
Discrepancies between model calculated $\mathrm{Cd}$ influx could be due to (a) wrong estimation of soil or plant parameters or (b) not all processes occurring in the rhizosphere were included. Root absorbing power ( $\alpha$ value) is a plant parameter that was calculated from study in solution culture (Stritsis, 2005). In nutrient solution experiment, $\mathrm{Cd}$ influx was linearly related to $\mathrm{Cd}$ concentration, and maize and sunflower had a similar influx but lower than flax and spinach (Stritsis, 2005 and Tab. 3-1) in the concentration range of interest, i.e., below $1 \mu \mathrm{M}$. Root absorbing power ( $\alpha$ value) differed among plant species.

A further possibility is the initial soil solution concentration $\left(\mathrm{C}_{\mathrm{Li}}\right)$ as soil parameter. It is a reliable model input parameter, which can be precisely measured. The displacement method permits accurate determination of the unaltered composition of soil solution (Adams 1974). Another difference to major nutrient is that there is almost no depletion of $\mathrm{Cd}$ in the rhizosphere, this as will be seen later is due to the much lower $\alpha$ value. In the lower concentration range, this relationship $\left(\mathrm{I}_{\mathrm{n}}=\alpha \times \mathrm{C}_{\mathrm{LO}}\right)$ is approximately linear for both the $\mathrm{Cd}$ as well as for $\mathrm{P}, \mathrm{K}$ and $\mathrm{Mn}$ but was much lower $\left(\alpha \approx 10^{-6} \mathrm{~cm} \mathrm{~s}^{-1}\right)$ than for $\mathrm{P}$ and $\mathrm{K}$, which are in the order of $\alpha \approx 10^{-4} \mathrm{~cm} \mathrm{~s}^{-1}$ (Sadana et al., 2005; Sayyari-Zahan et al., 2008). Therefore, sensitivity analysis for $\alpha$, and $\mathrm{C}_{\mathrm{Li}}$ should be conducted in order to find which parameter might have been wrongly estimated or influenced by plants in the rhizosphere. Another possibility to increase $\mathrm{Cd}$ soil solution concentration in the rhizosphere would have been through complexation of $\mathrm{Cd}$ in soil solution by plant root exudates.

Before we start the sensitivity analysis for $\alpha, C_{\mathrm{Li}}$ should first run the model with the original data to calculate $\mathrm{Cd}$ uptake and $\mathrm{Cd}$ influx as well as the $\mathrm{Cd}$ depletion in the rhizosphere. In this way, the model provides a better understanding of factors 
affecting the influence of $\mathrm{Cd}$ concentration on $\mathrm{Cd}$ uptake and causing the overestimation. Concentration profiles for $\mathrm{Cd}$ have not been calculated by other authors.

Figure $3-2 \mathrm{~A}$ and $3-3 \mathrm{~A}$ shows concentration profiles calculated using NST 3.0 at original $\mathrm{C}_{\mathrm{Li}}$ and $\alpha$ value. The model predicted that after 14 days of $\mathrm{Cd}$ uptake caused a decrease of $\mathrm{Cd}$ concentration at the root surface of maize and spinach causing a concentration gradient that was necessary for calculated uptake. If plants had decreased $\mathrm{Cd}$ concentration at the root surface to a lower value, they would have obtained a higher $\mathrm{Cd}$ influx, because of a higher concentration gradient for diffusion. The reduction of $C_{L O}$ was higher for spinach i.e. higher concentration gradient than that of maize but even so the model calculated for maize a 10-fold higher influx and for spinach of 1.5-fold higher, as measured. Obviously, this concentration $(0.19 \mu \mathrm{M})$ at the root surface of maize was too high and explained the overestimation. The overestimation could be based on a high $\alpha$ $\left(1.2 \times 10^{-6} \mathrm{~cm} \mathrm{~s}^{-1}\right)$, too. For spinach, the reduction of $C_{\mathrm{LO}}$ to $0.35 \mu \mathrm{M}$ was higher, but simulated closer the measured influx. The value of $\alpha\left(3.2 \times 10^{-6} \mathrm{~cm} \mathrm{~s}^{-1}\right)$ is also high and 3-fold higher than that of maize but lead to better results. These results suggest that the higher $\mathrm{Cd}$ influx of spinach was due to its capability to decrease solution $\mathrm{Cd}$ concentration at the root surface to a relatively lower value, thereby increasing the concentration gradient and consequently, the diffusive transport of $\mathrm{Cd}$ to the root surface. For maize, concentration gradient was very small hence calculated uptake was lower in comparison to spinach. This shows that the $\mathrm{Cd}$ transport in soil actually would be able to satisfy an even much higher Cd influx but maize could not realize at this $\mathrm{Cd}$ concentration. Therefore, $\mathrm{Cd}$ transport in 
soil is not limiting the uptake, but there is a close correlation between $\alpha$ value and the Cd influx.

The overestimate may be because the model does not consider the chemistry of $\mathrm{Cd}$ in soil solution such as chemical $\mathrm{Cd}$ mobilization (i.e. solubilization) or immobilization (i.e. insolubilization) and higher $\alpha$ value. Using sensitivity analysis, Sadana et al. (2005) found that underestimation based on lower soil-solution $\mathrm{Mn}$ concentration, $\mathrm{C}_{\mathrm{L} i}$, and the lower root absorbing power $\left(\mathrm{I}_{\max } / \mathrm{K}_{\mathrm{m}}\right)$. Similar, in this experiment it is necessary to run a sensitivity analysis to find possible reasons for difference between calculated and measured $\mathrm{Cd}$ influx. The starting point for the sensitivity analysis was the dataset of Tab. 3-1. Of this, initial soil solution concentration $\left(\mathrm{C}_{\mathrm{Li}}\right)$ and root absorbing power ( $\alpha$ value) were gradually reduced (Fig. 3-1 and Tab. 3-1).

The sensitivity analysis shows that either, $\mathrm{C}_{\mathrm{Li}}$, or $\alpha$ value should be decreased to reach the measured influx. A reduction of $\mathrm{C}_{\mathrm{Li}}$ at constant $\alpha$ should simulate a potential $\mathrm{Cd}$ complexation in soil solution caused by root activity. If $\mathrm{Cd}$ is taken up by plants as ion, $\mathrm{C}_{\mathrm{Li}}$ reduction is designed to find out the soil solution $\mathrm{Cd}$ concentration (i.e. effective concentration), which may use the plant to obtain a calculated similar to the measured influx. By decreasing $\mathrm{C}_{\mathrm{Li}}$ at constant $\alpha$ by a factor of 0.37 for spinach and 0.9 for maize, $100 \%$ agreement for $\mathrm{Cd}$ influx was achieved under $14 \mu \mathrm{mol} \mathrm{Cd} \mathrm{kg}{ }^{-1}$ addition (Fig. 3-2B and 3-3B). The model predicts that $\mathrm{Cd}$ uptake caused a decrease of $\mathrm{Cd}$ concentration at the root surface $\left(\mathrm{C}_{\mathrm{LO}}=\right.$ $0.019 \mu \mathrm{M})$ of maize, but since the $\mathrm{Cd}$ influx was very small, that concentration gradient also was very small $(0.003 \mu \mathrm{M})$ and was sufficient for calculated uptake. This shows that the soil is able to transport $\mathrm{Cd}$ to the root surface but maize cannot achieve a higher influx at this lower $\mathrm{Cd}$ concentration. For spinach, 
concentration gradient was higher $(0.17 \mu \mathrm{M})$ and obtained a higher influx. The effect of a decreasing $\mathrm{C}_{\mathrm{Li}}$ on the $\mathrm{Cd}$ influx may be referred to less $\mathrm{Cd}$ depletion at the root surface leading to lower $C d$ influx. The decreasing $C_{\mathrm{Li}}$ by maize may have been a mechanism i.e. through complexation of $\mathrm{Cd}$ by root exudates in soil solution or at root surface.

From the above it is understood that the soil release $\mathrm{Cd}$ and therefore the different root absorbing power, i.e., $\alpha$ value, will influence the uptake of $\mathrm{Cd}$ from the soil. A reduction of $\alpha$ value should simulate the root physiology under low stress condition without reduction of biomass. Guide value of root absorbing power was taken from nutrient solution experiment (Stritsis, 2005). For maize, the root absorbing power was reduced 10 times, $\alpha$ value was found in the soil growing maize plants (Chap. 2; Fig. 2-4). At the root surface of maize, the soil solution $\mathrm{Cd}$ concentration was already very low $\left(\mathrm{C}_{\mathrm{Li}}=0.22 \mu \mathrm{M}\right)$ with original $\alpha$ value (Fig. 3-2C), so by decreasing the $\alpha$ value to a lower value (90\%), there was not a decrease at the root surface but, on the contrary, an increase of $\mathrm{Cd}$ concentration $\left(C_{L O}=0.24 \mu M\right)$. In this case, limiting factor for $C d$ uptake was not soil $C d$ transport but uptake kinetics, i.e. $\alpha$ value. This increase of $C_{\mathrm{LO}}$ at the root surface is due to a lower Cd influx than the transport caused by convective $\mathrm{Cd}$ transport in soil (mass flow).

In contrast, $C d$ concentration at the root surface of spinach $\left(C_{L O}=0.48 \mu M\right)$ was much higher, so that root was able to decrease the concentration $\left(C_{\mathrm{LO}}=0.46 \mu \mathrm{M}\right)$ further, thereby creating a small concentration gradient to allow diffusive transport of Cd towards the root and on the other side to decrease the calculated Cd influx. 
Our previous results (Chap. 2) have shown that higher Cd influx was an important parameter for $\mathrm{Cd}$ accumulation in plants. In comparison to maize, spinach showed a high Cd shoot concentration even though the RA / SDW was low (Chap.2; Tab. 2-3) due to the high $\mathrm{Cd}$ influx. From the calculated concentration profiles around the root surface it is understood that the higher $\mathrm{Cd}$ influx in spinach was also due to its ability to reduce solution $\mathrm{Cd}$ concentration at root surface to a lower value as compared to maize. Nutrient uptake model NST 3.0 could not predict $\mathrm{Cd}$ influx and over-predicted $\mathrm{Cd}$ influx in all plants. The results showed that the Cd uptake was not explained without consideration of other not well-defined processes, such as chemical immobilization or complexation in soil solution (i.e. effective concentration). This high degree of sensitivity to $\mathrm{C}_{\mathrm{Li}}$ and $\alpha$ for maize indicate that uptake kinetics ( $\alpha$ value) was the major limiting factor for uptake and not $\mathrm{Cd}$ mobility through the soil towards the root. The amount of overestimation may indicate the dimension of the complexation influence, too. All plant species studied have different uptake kinetics and furthermore they seem to be able to change the composition of soil solution through root activity. 


\section{Cadmium Fractions in Soll as AfFected by PLANT GROWTH}

\subsection{Indroduction}

The results of Chapter 2 showed that plants vary in the amount of $\mathrm{Cd}$ they take up from soil. Main reason responsible for the variation in uptake was the $\mathrm{Cd}$ influx. The results furthermore showed that plants solubilized as well as immobilized $\mathrm{Cd}$ in soil. Model calculations (Chap.3) also indicated that $\mathrm{Cd}$ in soil solution may be partly present as chelate and not only as $\mathrm{Cd}^{2+}$ ion. This may indicate the ability of different plant species to influence and therefore, to access to different fractions of $\mathrm{Cd}$ in the soil.

The soil solution containing cations of elements such as $\mathrm{Fe}$ or $\mathrm{Cd}$ are in dynamic equilibrium with exchangeable cations sorbed to the solid phase or chelated to organic and inorganic ligands and it is most likely to be controlled by sorptiondesorption reactions at the soil particle surface (Swift and McLaren, 1991). The results of Chapter 2 suggest that the change of $\mathrm{Cd}$ solution concentration caused by the root system resulting in maize and spinach to reduce and flax to increase it. This may be due to metal cations being released into soil solution from pools, which were not previously in rapid equilibrium with the soil solution. This change will affect the equilibrium of $\mathrm{Cd}$ in soil solution with $\mathrm{Cd}$ fractions in soil solid phase or its distribution, and its chemical form in the soil. On the other side, could due to the formation of $\mathrm{Cd}$-compounds (organic or inorganic) in the rhizosphere, which has low solubility. This will be investigated by a fractionation of soil $\mathrm{Cd}$. 
Sorption of metal cations in soils is strongly influenced by soil characteristics and increased with increasing $\mathrm{pH}$, redox potential, organic matter, cation exchange capacity, and contents of iron and manganese oxides (Lindsay, 1979; Herms und Brümmer, 1980; Kuo und Baker, 1980; Sposito et al., 1981; Backes et al., 1995; Serrano et al., 2005).

From measured Cd concentration in extracted fractions in which $\mathrm{Cd}$ is bound some empirical estimate of $\mathrm{Cd}$ availability for root uptake can be made, although little research has been examining plant uptake in relation to the chemical $\mathrm{Cd}$ fraction in soil. Many extraction schemes for heavy metals have been recommended depending on the soil characteristics, the soil contamination status, and may include up to five steps (Tessier, 1979) or even up to eight steps (Ma and Uren, 1998 ) in order to compare with other procedures. Other extraction design for heavy metals has been defined through a one-step soil-extracting procedure involving, for example, sodium nitrate, DTPA, or EDTA to determine the plant available amount (Lindsay and Norvell, 1978; Gupta and Aten, 1993; Ure et al., 1993).

The use of sequential extraction with a progressive increase in displacement strength provides additional information about soil $\mathrm{Cd}$ fractions that may be released from soil and become available for plant uptake because of root exudation and other soil processes, e.g., the $\mathrm{Cd}$ fraction that is mobilised if the $\mathrm{pH}$ is lowered to 4 , or the fraction that may be mobilised from soil phase through root activity. Based on these partitioning into fractions, an assessment of plant availability and environmental influences of the heavy metals becomes possible, which cannot be derived from total element concentrations. Use of total concentration as a criterion to evaluate the potential effects on plant growth 
suggest that all forms of a given metal have an equal influence on uptake; such an hypothesis is clearly unlikely.

This study focuses on possible changes in the chemical $\mathrm{Cd}$ fractions in soil due to the growth of maize, sunflower, flax and spinach. The aim was to establish whether the activity of plant roots changes the chemical binding of $\mathrm{Cd}$ in contaminated soils and whether changes of $\mathrm{Cd}$ binding in soil affect the concentration in soil solution. To characterize the $\mathrm{Cd}$ binding in soil a fractionation of soil Cd was conducted with the sequential extraction after Zeien and Brümmer (1989). Seven fractions are determined sequentially with increasingly strong extractants. These fractions are: mobile fraction (F.I), easily mobilizable fraction (F.II), occluded in $\mathrm{Mn}$ oxides bound fraction (F.III), organically bound fraction (F.IV), occluded in poorly crystalline Fe oxide bound fraction (F.V), occluded in crystalline Fe oxides bound fraction (F.VI) and residual fraction (F.VII).

\subsection{Materials und Methods}

Soil $\mathrm{Cd}$ fractionation was carried out on the soil samples from the pot experiment of Chapter 2 using the method of Zeien and Brümmer (1989). The soil Cd fractions are extracted in the following sequence: mobile fraction (F.I), easily mobilizable fraction (F.II), occluded in Mn oxides fraction (F.III), organically bound fraction (F.IV), occluded in poorly crystalline Fe oxide fraction (F.V), occluded in Fe oxides well crystalline fraction (F.VI) and residual fraction bound (in silicate) Cd fractions (F.VII) in to the bulk soil. The sequential extraction of the seven Cd fractions occurred on the same soil sample with a 7 step washing procedure. 


\section{Extraction procedure}

I. Cd fraction: The mobile $\mathrm{Cd}$ fraction included water soluble and exchangeable (= nonspecifically adsorbed) $\mathrm{Cd}$ as well as soluble metallorganic $\mathrm{Cd}$ complexes. For this fraction $1.0 \mathrm{~g}$ dried, sieved $(<2 \mathrm{~mm})$ of the soil sample was put in $50 \mathrm{~mL}$ acidcleaned centrifuge beaker. $25 \mathrm{~mL}$ of $\mathrm{NH}_{4} \mathrm{NO}_{3}$ (1M not $\mathrm{pH}$ adjusted) was added and the beaker was shaken overhead for 24 hours. After centrifugation for 10 minutes at $2500(\mathrm{r} / \mathrm{min})$ at $20^{\circ} \mathrm{C}$ the solution was decanted over folded filter in $100 \mathrm{~mL}$ polyethylene bottles and the filtrate stored at $6^{\circ} \mathrm{C}$. For stabilization of the filtrates $0.25 \mathrm{~mL}$ conc. $\mathrm{HNO}_{3}$ were added.

II. Cd fraction: In centrifuge beaker to the remaining soil sample $25 \mathrm{~mL} \mathrm{NH} \mathrm{NHAc}_{4}$ (1M adjusted to $\mathrm{pH} 6$ with acetic acid) was added to extract the easily mobilizable $\mathrm{Cd}$ fraction. The II fraction contains $\mathrm{Cd}$ specifically adsorbed, occluded close to particle surfaces, bound to carbonates and extracted from metal-organic complexes of low stability. The solution with $\mathrm{NH}_{4} \mathrm{OAc}$ was shaken overhead for 24 hours and centrifuged for 10 minutes at $2500(\mathrm{r} / \mathrm{min})$ at $20^{\circ} \mathrm{C}$. The supernatant was decanted over folded filter in $100 \mathrm{~mL}$ polyethylene bottles und the remaining rest solution was twice washed (10 min overhead shaken) with $12.5 \mathrm{~mL}$ of $\mathrm{NH}_{4} \mathrm{NO}_{3}$ (1M not pH adjusted). The supernatant was each time decanted again in the 100 $\mathrm{mL}$ polyethylene bottles (filtrates were united). To the filtrates $0.25 \mathrm{~mL}$ conc. $\mathrm{HNO}_{3}$ were added to stabilize the solution.

III. Cd fraction: After extraction of fraction II, $25 \mathrm{~mL}$ solution consisting of $\mathrm{NH}_{2} \mathrm{OH}-$ $\mathrm{HCl}(0.1 \mathrm{M})$ and $\mathrm{NH}_{4} \mathrm{OAc}(1 \mathrm{M})$ adjusted to $\mathrm{pH} 6$ with $5 \mathrm{M} \mathrm{HCl}$ were added to the centrifuge tube to extract the III Cd fraction. This fraction is considered occluded in $\mathrm{Mn}$ oxides plus residual specifically adsorbed and small proportions of 
organically bound heavy metals. The beaker was shaken overhead for $30 \mathrm{~min}$ and centrifuged for 10 minutes at $2500(\mathrm{r} / \mathrm{min})$ at $20^{\circ} \mathrm{C}$. The supernatant was decanted over folded filter in $100 \mathrm{~mL}$ polyethylene bottles und the remaining soil was two times washed (10 min overhead shaken) with $12.5 \mathrm{~mL}\left(1 \mathrm{M} \mathrm{NH}_{4} \mathrm{OAc}\right.$ adjusted to $\mathrm{pH}$ 6 with acetic acid). The supernatant was each time decanted again into the 100 $\mathrm{mL}$ polyethylene bottles (filtrates were united). Into the filtrates $0.25 \mathrm{~mL}$ conc. $\mathrm{HNO}_{3}$ were added to stabilize the solution.

IV. Cd fraction: The extractant for this fraction consisted of $\mathrm{NH}_{4}$-EDTA (0.025M) and $\mathrm{NH}_{4} \mathrm{OAc}(1 \mathrm{M})$ adjusted to $\mathrm{pH} 4.6$ with acetic acid to get the organically bound Cd. $25 \mathrm{~mL}$ of this solution were added into centrifuge beaker, overhead shaken for $90 \mathrm{~min}$ and centrifuged for 10 minutes at $2500(\mathrm{r} / \mathrm{min})$ at $20^{\circ} \mathrm{C}$. The supernatant was decanted over folded filter into $100 \mathrm{~mL}$ polyethylene bottles. To recover the solution with the heavy metals remaining in the soil sample, the soil sample was mixed with $12.5 \mathrm{~mL}$ of $1 \mathrm{M} \mathrm{NH}_{4} \mathrm{OAc}$ (adjusted to $\mathrm{pH} 4.6$ with acetic acid), overhead shaken for $10 \mathrm{~min}$, then centrifuged and filtered. The collected filtrates were united and stored at $6^{\circ} \mathrm{C}$.

V. Cd fraction: To extract the $\mathrm{Cd}$ assumed to be occluded in poorly crystalline Feoxides, the soil sample remaining in the centrifuge beaker was mixed with $25 \mathrm{~mL}$ of $0.2 \mathrm{M} \mathrm{NH}_{4}$-oxalate solution ( $0.2 \mathrm{M}$ di-ammonium oxalate monohydrate and 0.2 $\mathrm{M}$ oxalic acid dihydrate with ammonia solution adjusted at $\mathrm{pH} 3.25$ ) overhead shaken for 4 hours in darkness and centrifuged for 10 minutes at $2500(\mathrm{r} / \mathrm{min})$ at $20^{\circ} \mathrm{C}$ and the supernatant was decanted over folded filter in $100 \mathrm{~mL}$ polyethylene bottles. In a subsequent wash, $12.5 \mathrm{~mL}$ of $0.2 \mathrm{M} \mathrm{NH}_{4}$ oxalate solution were added in the remaining soil sample, overhead shaken for 10 minutes in darkness then 
centrifuged and filtered as above. Then the resulting filtrates were united and stored at $6^{\circ} \mathrm{C}$ in darkness.

VI. Cd fraction: To the soil sample remaining in the centrifuge tube $25 \mathrm{~mL} 0.1 \mathrm{M}$ of ascorbic acid and $0.2 \mathrm{M} \mathrm{NH}_{4}$ oxalate solution (adjusted at $\mathrm{pH} 3.25$ such as $\mathrm{Cd}$ fraction V) were added for extraction of Cd occluded in crystalline Fe-oxides. After adding of extracting agent, sample was treated for 30 minutes in water bath at $96 \pm 3^{\circ} \mathrm{C}$. Following was centrifuged for 15 minutes at $2500(\mathrm{r} / \mathrm{min})$ at $20{ }^{\circ} \mathrm{C}$ and the supernatant was decanted over folded filter in $100 \mathrm{~mL}$ polyethylene bottles. For washing, the soil sample was shaken overhead once with $12.5 \mathrm{~mL}$ of $0.2 \mathrm{M}$ $\mathrm{NH}_{4}$ oxalate solution (adjusted at $\mathrm{pH} 3.25$ such as $\mathrm{Cd}$ fraction $\mathrm{V}$ ) for 10 minutes in darkness, then centrifuged and filtered as above. Then the filtrates were united and stored at $6^{\circ} \mathrm{C}$ in darkness.

VII. Residual fraction: As the last fractionation step, the soil sample is subjected to total digestion. The soil sample remaining in the centrifuge beaker is transferred to a $250 \mathrm{~mL}$ glass flask and then $10.5 \mathrm{~mL}$ of concentrated $\mathrm{HNO}_{3}(65 \%)$ and $3.5 \mathrm{~mL}$ of concentrated $\mathrm{HCl}(37 \%)$ were added. To avoid uncontrolled reaction processes during the digestion process, samples were pre-treated $45 \mathrm{~min}$ at $70{ }^{\circ} \mathrm{C}$, than 30 min at $110{ }^{\circ} \mathrm{C}$ and finally $180 \mathrm{~min}$ at $120{ }^{\circ} \mathrm{C}$ until it reached a whitish-gray appearance of the soil sample. The residue was transferred with water into glass flasks and filtered in $100 \mathrm{~mL}$ polyethylene bottles. All filtrates of extracted solution were analyzed for $\mathrm{Cd}$ concentration using graphite furnace atomic absorption spectrometer GFAAS. The limits of detection were $2 \mu \mathrm{g} \mathrm{L}^{-1}$. Total Cd content in soils was determined by digesting $0.2 \mathrm{~g}$ of dried soil with $3 \mathrm{~mL}$ of $\mathrm{HNO}_{3}(65 \%)$ in teflon box under high pressure at $180^{\circ} \mathrm{C}$ followed by analysis. 
The $\mathrm{Cd}$ determinations were always performed with D2 deuterium background correction and with graphite tube and platform. During the $\mathrm{Cd}$ determination with GFAAS significant matrix problems occurred which were primarily attributable to the use of highly concentrated salt solutions. The problem of the high concentrated salt solutions could often be improved through strong dilution. The optimization of measurement parameters (temperature control and atomization time) brought a reduction of matrix problems or improved the reproducibility (Tab.8-2).

For more details of the extraction procedure and characterization of the different Cd fraction see Zeien and Brümmer (1989) and Zeien (1995).

\subsection{Results}

Figure 4-1 shows that plants growth affected the $\mathrm{Cd}$ content of the different $\mathrm{Cd}$ fractions, causing not only $\mathrm{Cd}$ depletion but also an increase, which could be described as a Cd immobilization. These effects varied among plant species. Fraction I (the mobile Cd) was decreased by all species, this decrease was in tendency smaller for maize than for the other species.

In F.II (easily mobilizable Cd) maize and spinach increased while flax decreased the content of this fraction and sunflower had no effect. Fraction III (Cd occluded in Mn oxide) was not affected by maize and flax while sunflower and spinach reduced its content. The organically bound Cd (F.IV) was increased by maize and flax but sunflower and spinach had no affect on it. The amount of Cd present in V, VI, VII fractions was only around $5 \%$ of total $\mathrm{Cd}$ and was therefore not considered separately (Appendix Tab.8-1). 

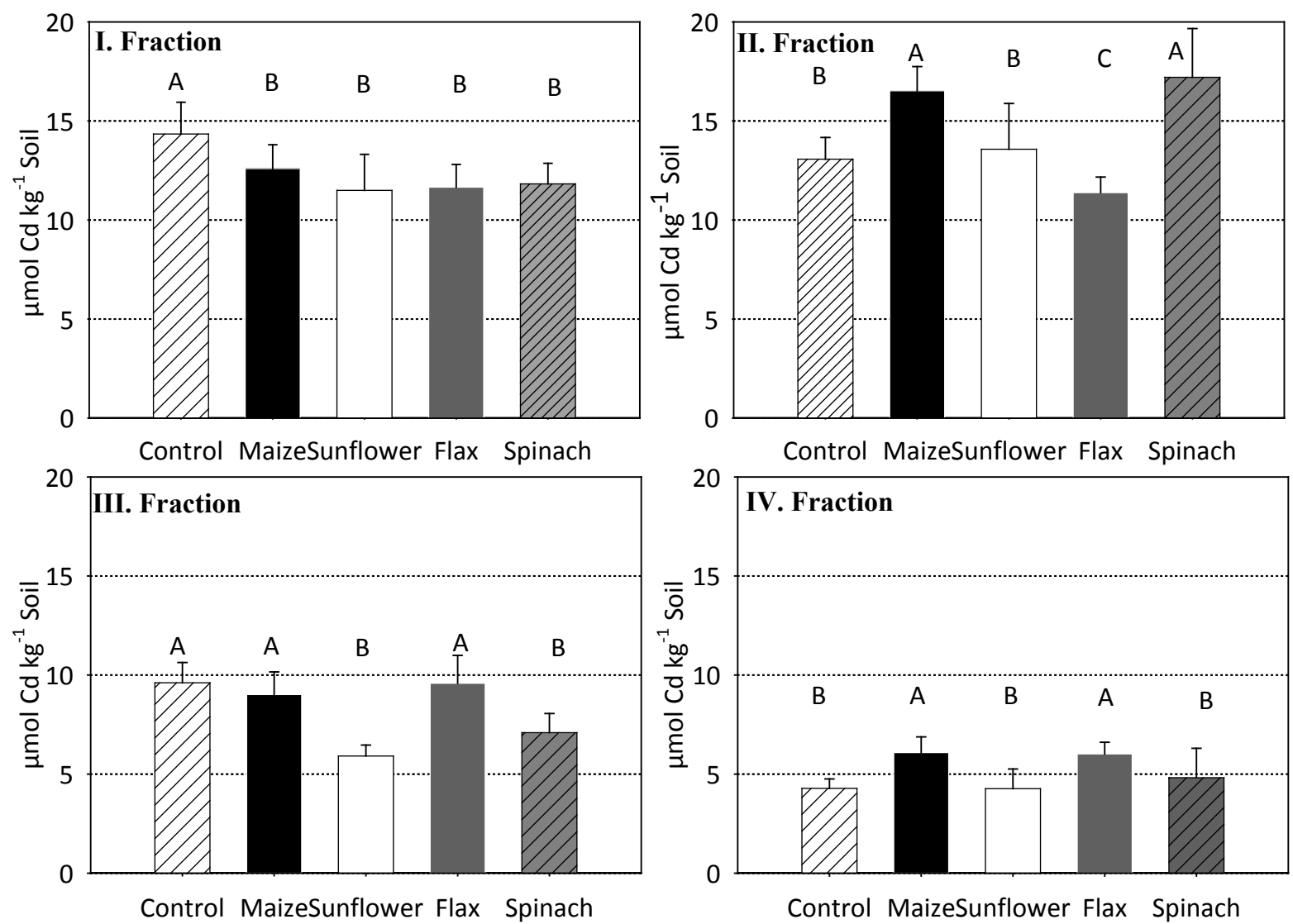

Figure 4-1 Cadmium in the first four fractions by comparison at $40 \mu \mathrm{mol} \mathrm{Cd} \mathrm{g}^{-1}$ addition in soil. Different upper case letters show significant differences among plant and fractions (\$ 0.01; Student-Newmann-Keuls method).

Figure 4-2 shows the distribution of $\mathrm{Cd}$ among the different fractions as affected by plant growth. In control soil, Cd was mainly found in the mobile and easily mobilizable fraction (64\%). Significant concentrations of $\mathrm{Cd}$ were found in F.III (22\%) and F.IV (10\%). Fractions V, VI, VII amounted to less than 5\% of their total Cd concentration (Appendix Tab. 8-2). The plants have a different profile in comparison to control. 


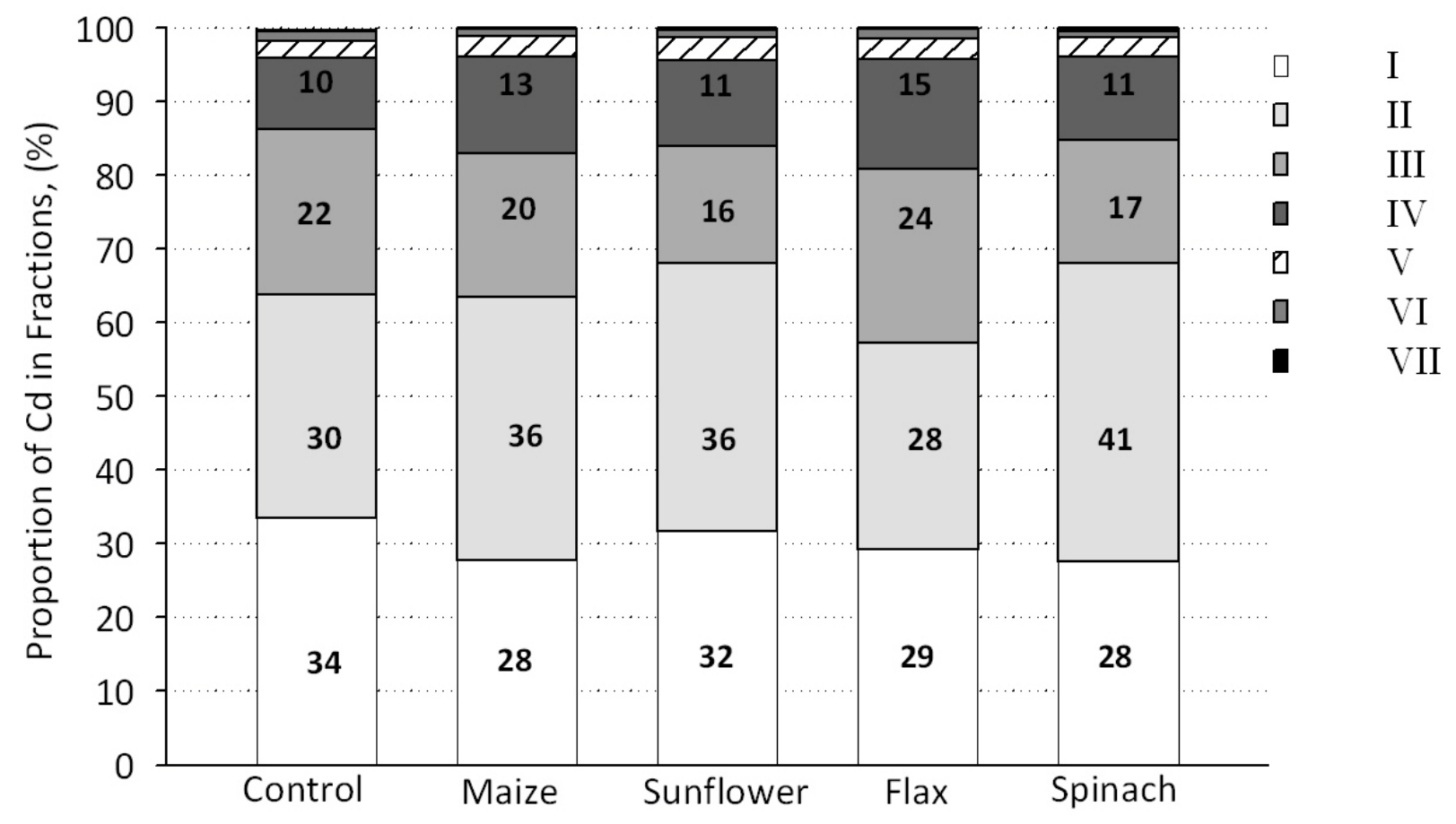

Figure 4-2 Percentage distribution of $\mathrm{Cd}$ in the run of the experiment on the 7 fractions of sequential extraction in soil after $40 \mu \mathrm{mol} \mathrm{kg}{ }^{-1} \mathrm{Cd}$ addition.

For spinach and sunflower about $70 \%$ of $\mathrm{Cd}$ was found in F.I and F.II while flax had only $57 \%$. In maize and sunflower, the F.II increased slightly (about $6 \%$ ) whereas in spinach it increased more (11\%). Flax had similar Cd content as the control in the F.II but a decrease of $6 \%$ in the F.I. Concomitant, the contents of $\mathrm{Cd}$ in the F.III were a little changed by maize and flax. Remarkable is the increase of the F.IV in maize $(3 \%)$ and flax (5\%) in comparison to the control. Fractions $\mathrm{V}, \mathrm{VI}$, and VII together contain less than $5 \%$ of the total $\mathrm{Cd}$.

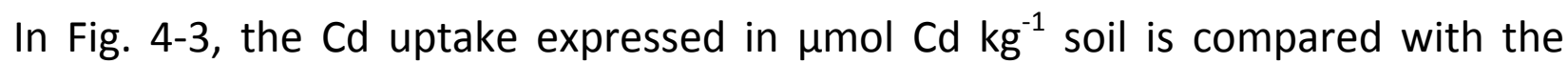
changes of $\mathrm{Cd}$ content of the different Cd fractions, also expressed in $\mu \mathrm{mol} \mathrm{Cd} \mathrm{kg}{ }^{-1}$ soil. The lowest $\mathrm{Cd}$ uptake was found in maize and rose significantly from sunflower and flax to spinach. Looking at the change of the $\mathrm{Cd}$ content in each fraction, then the mobile fraction shows the biggest changes. Here, the decrease 
in $\mathrm{Cd}$ content of fraction I except maize $(1.6 \mu \mathrm{mol} \mathrm{Cd} \mathrm{kg})$ were comparable higher (about $2.5 \mu \mathrm{mol} \mathrm{Cd} \mathrm{kg}^{-1}$ ).
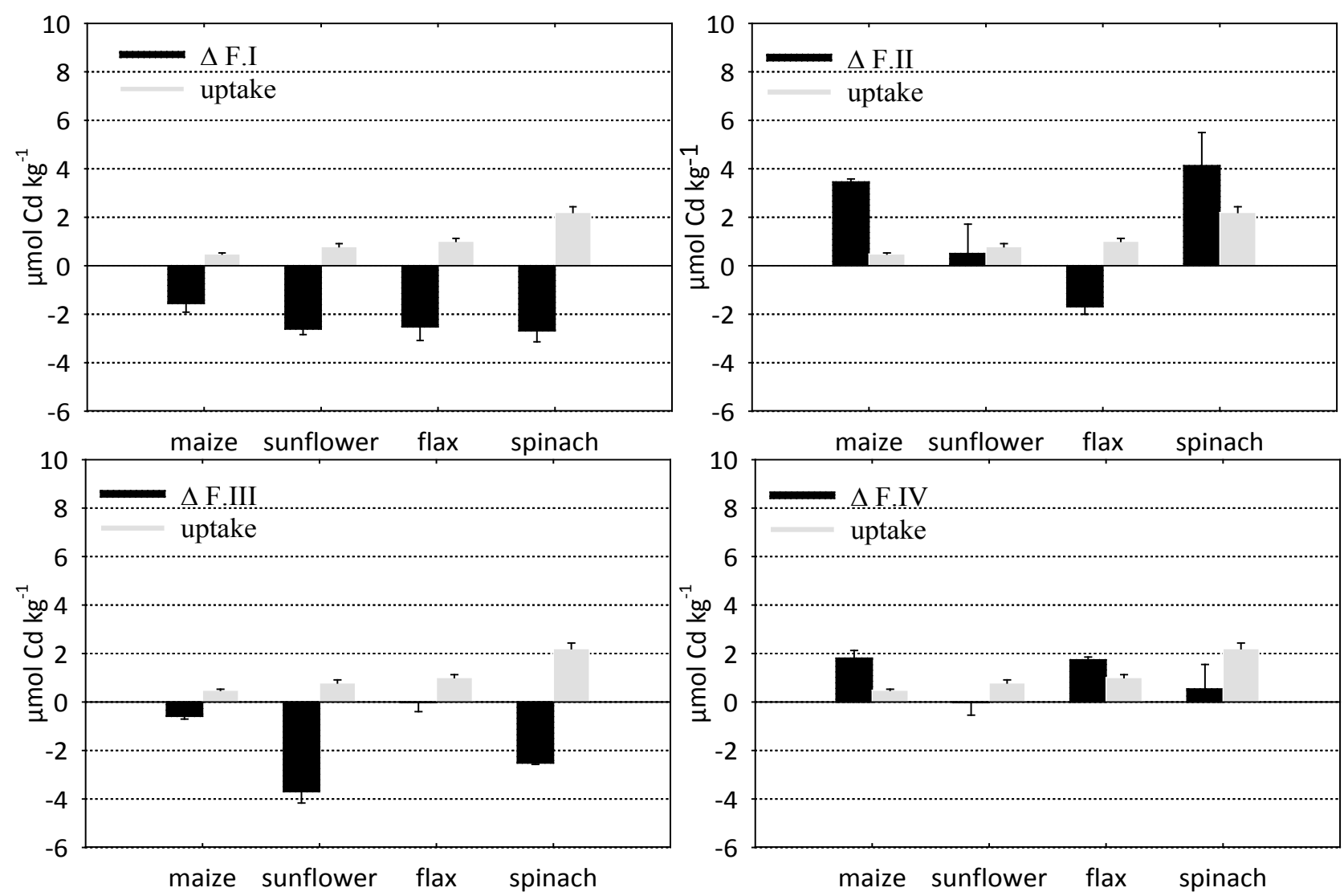

Figure 4-3 Comparison of $C d$ uptake by different plants species with the change $(\Delta)$ of $C d$ in soil Cd fractions I, II, III, IV caused by plant growth.

The plant effect on the Cd content in fraction II was very different, i.e. it increased and only with flax $\left(1.7 \mu \mathrm{mol} \mathrm{Cd} \mathrm{kg}{ }^{-1}\right)$ it decreased. For fraction III, the Cd content decreased strongly in sunflower $\left(3.7 \mu \mathrm{mol} \mathrm{Cd} \mathrm{kg}{ }^{-1}\right)$ and spinach $\left(2.5 \mu \mathrm{mol} \mathrm{Cd} \mathrm{kg}{ }^{-1}\right)$, while in maize and flax there was no change. In fraction IV the $\mathrm{Cd}$ content increased clearly in maize and flax $\left(1.7 \mu \mathrm{mol} \mathrm{Cd} \mathrm{kg}{ }^{-1}\right)$ while in spinach the increase was very low and sunflower had no effect. 
Cadmium in soil solution (Chap. 2; Fig. 2-3) as well as the different Cd fraction varied strongly among plant species. Since $\mathrm{Cd}$ in soil solution is in equilibrium with $\mathrm{Cd}$ in the solid phase we tried to find out which of the fraction might be controlling Cd concentration in the soil solution.
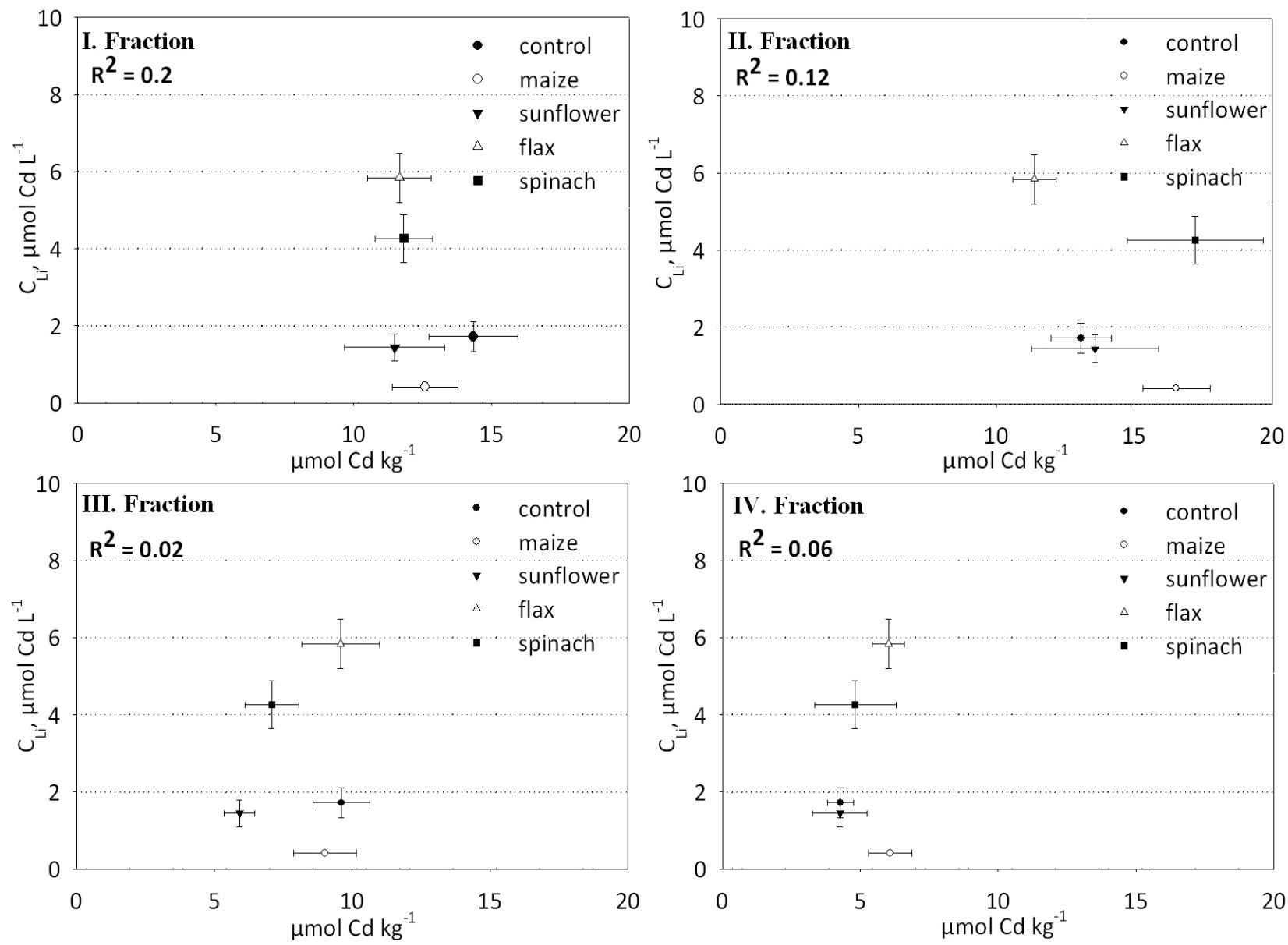

Figure 4-4 Relationship between $\mathrm{Cd}$ concentration in soil solution, $\mathrm{C}_{\mathrm{L}}$, at second harvest and $\mathrm{Cd}$ contents in $\mathrm{Cd}$ fractions I, II, III, IV.

Figure 4-4 shows the relationships between the $\mathrm{Cd}$ in soil solution and the $\mathrm{Cd}$ content in the different fractions. With $r^{2}$-values from 0.02 to 0.2 shows that there is no clear relationship between the soil solution concentration and the total content of any of the fractions. Spinach and flax have always more $\mathrm{Cd}$ in the soil solution as maize and sunflowers. Since according to model calculation (Chapter 3 ) 
the ionic $\mathrm{Cd}$ concentration in soil solution was much different from total $\mathrm{Cd}$ in soil solution we also plotted the $\mathrm{Cd}$ concentration as estimated by the model against Cd content of the different $\mathrm{Cd}$ fractions. This is shown in Figure 4-5. It can be seen, the correlation coefficients for $\mathrm{Cd}$ obtained are better than with the original concentration but as in the $\mathrm{C}_{\mathrm{Li}}$ (Fig. 4-4) no relationship could be established for $\mathrm{Cd}$ with either soil $\mathrm{Cd}$ fraction. It should also be noted that ammonium nitrate extraction resulted in much better correlations $\left(r^{2}=0.45\right)$ for $C d$ than in the other fractions.
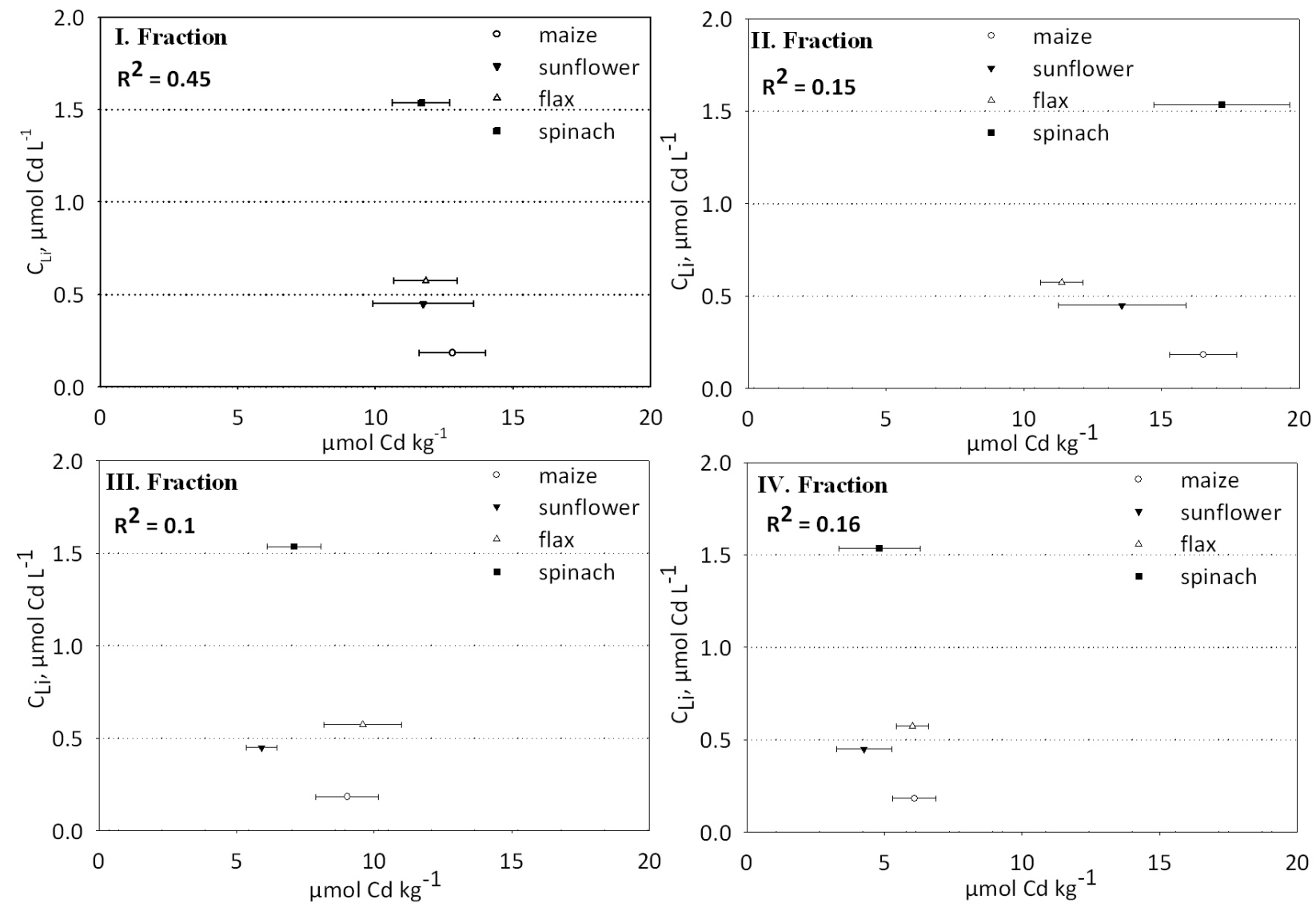

Figure 4-5 Relationship between the Cd content in Cd fractions I, II, III, IV and the varying concentration, $\mathrm{C}_{\mathrm{Li}}$, of $\mathrm{Cd}$ in the soil solution (average between first and second harvest) getting from sensitivity analysis. $\mathrm{C}_{\mathrm{Li}}$ is the $\mathrm{Cd}$ concentration in solution at which calculated and measured $\mathrm{Cd}$ influx was equal. 


\subsection{Discussion}

Cadmium distribution among specific chemical forms in soil varies widely because soils consists of heterogeneous mixtures of organic and inorganic solid components as well as a variety of soluble substances and based on the $\mathrm{Cd}$ chemical properties and soil characteristics. With the sequential extraction, it is intended to understand the interactions between $\mathrm{Cd}$ and soil components, as well as to determine the distribution of $\mathrm{Cd}$ among binding forms. The relative binding strength of $\mathrm{Cd}$ at different solid phases can estimate the potential reactivity of $\mathrm{Cd}$ under different environmental conditions and thus identify the environmental effectiveness of $\mathrm{Cd}$ in soil. The sequential extraction used in this study was developed to assess the form of Cd binding in the soils (Zeien, 1995) and the mobility (i.e. extractability) is defined as the extracted $\mathrm{Cd}$ amount from organic and inorganic solid components. Hence, sequential extraction can give an indication of the binding strength of $\mathrm{Cd}$ in soil and its potential for distribution over time due to changes in soil chemistry. The seven binding fractions of $\mathrm{Cd}$ are operationally defined by an extraction sequence that follows the order of increasing acidity with extractants of different complexing and redox properties (Zeien and Brümmer, 1989; Zeien and Brümmer, 1991; Zeien, 1995). The advantage this methods over other, is that it was developed to determine heavy metal binding form in soils with oxidizing conditions and with less than $5 \%$ carbonate content. A further advantage of this method was the minimization of matrix problems as compared to the previously proposed methods for sequential extraction procedure (Zeien, 1995). It should also be noted that this sequential extraction procedure presents certain analytical problems that lead to deviation from the actual amount of $\mathrm{Cd}$ added to soil. However, comparison of the sum of the $\mathrm{Cd}$ concentrations in the individual fractions with the total $\mathrm{Cd}$ concentration 
shows satisfactory agreement for plants. From the Tab 8-1 in the Appendix, there is a deviation (5-15\%) of the sum of fractions of the sequential procedure in relation to the total amount of $\mathrm{Cd}$ that was determined separately with acid digestion $\left(65 \% \mathrm{HNO}_{3}\right)$. Similar problems and deviation associated with the selectivity of the reagents and the occurrence of analytical problems during this sequential extraction have been observed and commented on other investigations (Zeein 1995; Keppler 1999; Keller 2000; Domeyer 2006).

Cadmium concentrations of individual fractions of the sequential extraction analysis are shown in Fig. 4-1 both with plant growth and without. The amounts of Cd extracted by the seven extractants were different without plants. Supposing that bioavailability is related to binding forms, then $\mathrm{Cd}$ bioavailability increases in the order: Fraction VII (F.VII) $<$ Fraction VI $(F . V I)<$ Fraction V (F.V) $<$ Fraction IV (F. IV) < Fraction III (F.III) < Fraction II (F.II) < Fraction I (F.I). This order is just a generalization and shows only qualitative information about $\mathrm{Cd}$ bioavailability and mobility (i.e. extractability). The mobility in soils is determined by solution and precipitation reactions as well as adsorption and desorption reactions in conjunction with complexation processes of organic and inorganic substances. Cadmium is bound in soils, both specific and nonspecific to the surfaces of many adsorbents with variable adsorption capacity and binding strength. In the sandy

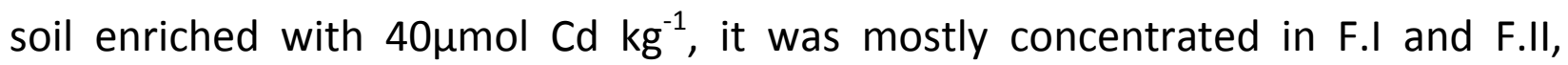
although it was also present in other fractions (Fig. 4-1). The high proportion of Cd in F.I $\left(14.3 \mu \mathrm{mol} \mathrm{Cd} \mathrm{kg}{ }^{-1}\right)$ and in F.II $\left(13.1 \mu \mathrm{mol} \mathrm{Cd} \mathrm{kg}{ }^{-1}\right)$ in soil without plants reflects the greater tendency of $\mathrm{Cd}$ to bind as exchangeable in this soil. The $\mathrm{Cd}$ in F.I is primarily non-specifically adsorbed by electrostatic attraction of negatively charged surfaces (Brümmer et al., 1986; Sposito 1998, pp127-147; 
Scheffer/Schachtschabel 2002, pp378-382). The use of electrolytes, such as $\mathrm{NH}_{4} \mathrm{NO}_{3}$, in the extraction solution achieves displacement of $\mathrm{Cd}$ ions held by electrostatic attraction to negative sites on particle surfaces. The $1 \mathrm{M} \mathrm{NH}_{4} \mathrm{NO}_{3}$ fraction is in a concentration-dependent relationship on the one hand to the soil solution and the other hand to the stronger binding forces specifically bound $\mathrm{Cd}$ fractions. These provide with modified $\mathrm{pH}$ either a replenishment pool or a provisional fractional accumulation of $\mathrm{Cd}$. In sandy soil occurred increased F.I because of the strongly acidic soil reaction $(\mathrm{pH} 4.4-4.5)$ and absorbed area of organic matter $\left(\mathrm{C}_{\text {org }} 2.8 \%\right)$ that they have a high $\mathrm{pH}$-dependent binding capacity for Cd.

The extraction capacity of $1 \mathrm{M} \mathrm{NH} \mathrm{N}_{4} \mathrm{OAc}$ solution $(\mathrm{pH}$ 6.0) of $\mathrm{Cd}$ F.II to extract specifically adsorbed $\mathrm{Cd}$ is based on the dispersing ability of the $\mathrm{NH}_{4}{ }^{+}$cation and the complexing ability of the acetate anion. The $\mathrm{NH}_{4} \mathrm{OAc}$ solution displaces $\mathrm{Cd}$ close to surface binding sites of clay minerals and oxides, carbonates bond forms, and organometallic complexes of low binding strength (Herms and Brümmer, 1984; Brümmer et al., 1986; Zeein 1995). With increasing soil acidification a shift of the binding affinities from higher towards lower binding strength, might be occurred i.e. unspecific adsorption leading in an increased proportion of mobile $\mathrm{Cd}$ (Zeein 1995). The pH significantly influenced the sorption behavior of soil substances so that can also contribute slightly soluble organometallic complexes in a medium acidic $\mathrm{pH}$ range $(5.0-5.9)$ to an increased $\mathrm{Cd}$ solubility (Herms und Brümmer, 1978; Zeien 1995). Furthermore, Cd desorption in soil increases significantly at pH $<6.5$ (Herms and Brümmer 1980; Ratuzny et al., 2009). From the above it is understood that on the adsorbent surface is more likely to present 
a continuum rather than a sharply defined change between binding sites of different binding energies (Tiller et al., 1984a, 1984b).

In this study, the $\mathrm{Cd}$ bound in F.III in control soil was $9.6 \mu \mathrm{mol} \mathrm{Cd} \mathrm{kg}^{-1}(22 \%)$. Manganese in soils under aerobic conditions is mainly present as $\mathrm{Mn}$-oxides and hydroxides as well as in Mn-Fe mixed oxides with high surface activity, which can affect the $\mathrm{Cd}$ content in soils because are able to bind strong $\mathrm{Cd}$ (Brümmer et al., 1983; Sposito 1998; Scheffer/Schachtschabel 2010, p136). The use of $0.1 \mathrm{M}$ $\mathrm{NH}_{2} \mathrm{OH}-\mathrm{HCl}+1 \mathrm{M} \mathrm{NH}_{4} \mathrm{OAc}$ at a $\mathrm{pH}$ of 6.0 is based on the reductive dissolution of $\mathrm{Mn}$ oxides under consideration to a good separation of $\mathrm{Cd}$ bound in Fe-oxides (Chao 1972; Zeein 1995).

The $\mathrm{Cd}$ bound to organic matter in F.IV was low $\left(5 \mu \mathrm{mol} \mathrm{kg}{ }^{-1}\right.$ or $\left.10 \%\right)$. Cadmium associated with organic substance is either adsorbed or complexed. By using the strong complexing agent $0.025 \mathrm{M} \mathrm{NH}_{4}$-EDTA combined with $1 \mathrm{M} \mathrm{NH}_{4} \mathrm{OAc}$ at $\mathrm{pH}$ 4.6, a selective detection of $\mathrm{Cd}$ bound to stable organic complexes is obtained. The superiority of $0.025 \mathrm{M} \mathrm{NH}_{4}$-EDTA is due to a complete complexation of organicbound Cd fractions (Zeein 1995).

According to Ratuzny et al. (2009) using the same extraction procedure, Cd was mainly found in F.I (27.6\%), F.II (26.9\%) and F.III (25.0\%) in acid soils (pH 5.0-6.5). The same extraction order, F.I > F.II > F.III (about 75\%), was also reported for other forest soil with pH 5.04 (Keppler, 1999).

Sequential extractions might give the information needed to explain different uptake efficiencies for different metals such as $\mathrm{Cd}$. Figure 4-2 shows the relative change of the respective $\mathrm{Cd}$ fractions by plants while Figure 4-3 points the relationship between $\mathrm{Cd}$ uptake and change of $\mathrm{Cd}$ soil fractions of plants in 
comparison to control soil. For all plants, the first four fractions were changed by 5\% on average. Comparisons in Fig. 4-1 and Fig. 4-3 indicate that after 43 days of germination, plants reduced $\mathrm{Cd}$ associated with F.I in the soil. The negative change was remarkable because F.I could have positive influence on $\mathrm{Cd}$ release into soil solution and therefore could explain the Cd uptake of all plants. However, we are not sure whether the entire Cd was correlated with Cd uptake, because there is no clear relationship between $\mathrm{Cd}$ content in F.I and $\mathrm{Cd}$ concentration in soil solution (Fig. 4-4 and see below). To this, Brümmer et al. (1998) emphasize that F.I on lower contaminated soil was less meaningful for transfer into the plant. Further studies by Singh and Myhr (1997) causes an increased Cd addition to the soil high levels of $\mathrm{NH}_{4} \mathrm{NO}_{3}$-extractable $\mathrm{Cd}$, but this relationship was not confirmed in the $\mathrm{Cd}$ contents in plants.

On the other hand, the $\mathrm{Cd}$ content of soil planted with maize and spinach increased the content of F.II indicating a change in the Cd distribution (Fig. 4-1). In Figure 4-3 is only recorded a negative change of $\mathrm{Cd}$ in the soil grown to flax (1.7 $\left.\mu \mathrm{mol} \mathrm{kg}{ }^{-1}\right)$ whereas in maize $\left(3.5 \mu \mathrm{mol} \mathrm{kg}{ }^{-1}\right)$ and spinach $\left(4 \mu \mathrm{mol} \mathrm{kg}{ }^{-1}\right)$ is noticed a positive change. The F.II of soil planted with maize and spinach was observed a high bond of $\mathrm{Cd}$ that could be explained by the high extractability of $\mathrm{Cd}$ using the $1 \mathrm{M} \mathrm{NH} \mathrm{NH}_{4} \mathrm{OAc}\left(\mathrm{pH}\right.$ 6.0). This extraction behavior of $1 \mathrm{M} \mathrm{NH}_{4} \mathrm{OAc}$ (at $\mathrm{pH} 6.0$ ) is characterized by a partial extraction of organometallic complexes of low bond strength (Zeein 1995) which may be derived from the root. Results of Gransee et al. (1998) show that root exudates of maize were composed to $75 \%$ of sugars, to $17 \%$ of amino acids and amides and to $8 \%$ of carboxylic acids organic substance with low adsorptive capacity. Keller (2000) reported that the dominant component in the acid samples of spinach (Monnopa) was oxalic acid. In addition, 
it could find with comparable mean excretion rates of citric acid, malic acid, malonic acid, succinic acid and lactic acid. In addition, small amounts were at 2-oxoglutaric, acetic acid and fumaric acid. The difference organic acid profile could be an explanation for the higher amount of $\mathrm{Cd}$ extracted from F.II of maize and spinach samples and lower of flax samples indicating a root exudation that caused a different $\mathrm{Cd}$ content in comparison to control soil. The negative change in F.II $\left(1.7 \mu \mathrm{mol} \mathrm{kg}{ }^{-1}\right)$ of soil planted with flax is similar to the positive change in F.IV $\left(1.7 \mu \mathrm{mol} \mathrm{kg}{ }^{-1}\right)$ whenever there is a distribution of $\mathrm{Cd}$. The distribution could be explained with a different exudation profile i.e. exudation of substance with high molecular weight. Besides, in case of flax the change in F.ll could explain the Cd uptake while for maize and spinach it is not possible.

Effect on the Cd quantity was found in extraction of F.III, too. The reductive dissolution of $\mathrm{Mn}$ oxides caused from $0.1 \mathrm{M} \mathrm{NH}_{2} \mathrm{OH}-\mathrm{HCl}+1 \mathrm{M} \mathrm{NH}_{4} \mathrm{OAc}$ at a pH of 6.0 can result in complete or partial dissolution of any $\mathrm{Mn}$ oxides present, a dissolution process that can release $\mathrm{Cd}$ ions associated with these soil components. Among plants, the $\mathrm{Mn}$ oxide fraction contained the greatest amount of $\mathrm{Cd}$ in control soil, maize and flax in comparison to sunflower and spinach (Fig. 4-2). It is remarkable that $\mathrm{Cd}$ in soil of sunflower and spinach showed a low value in the F.III of the procedure in comparison to control soil. A low proportion of $\mathrm{Cd}$ in the fraction bound to $\mathrm{Mn}$ oxides indicates that probably a considerable change in the oxygen content (e.g. due to root or bacterial activity during the vegetation period) can reduce the redox potential in rhizosphere to values sufficiently low to achieve reduction of $\mathrm{Mn}$ and therefore to affect the $\mathrm{Cd}$ content. In the rhizosphere of sunflower, field beans and peas Fischer et al. (1989) as well as Flessa and Fisher (1992) found root-induced reduction reactions while in the 
rhizosphere of wheat and oat showed no change in redox potential. Observing the changes of $\mathrm{Cd}$ will confirm a significant reduction in sunflower $\left(3.7 \mu \mathrm{mol} \mathrm{kg}^{-1}\right)$ and a little in spinach $\left(2.5 \mu \mathrm{mol} \mathrm{kg}{ }^{-1}\right)$.

A negative change of $\mathrm{Cd}$ content indicates that the rhizosphere of sunflower and spinach could affect the $\mathrm{Cd}$ content. For Cd uptake, we can not certainly draw conclusions because both the F.III and the F.I could cover Cd uptake of sunflower $\left(0.8 \mu \mathrm{mol} \mathrm{kg}{ }^{-1}\right)$ and spinach $\left(2.2 \mu \mathrm{mol} \mathrm{kg}{ }^{-1}\right)$. It is also difficult to find a distribution of $\mathrm{Cd}$ especially in the case of sunflower. The negative change in the maize (0.6 $\mu \mathrm{mol} \mathrm{kg}{ }^{-1}$ ) was almost similar to the $\mathrm{Cd}$ uptake (Fig. 4-3). This change was enough to explain the $\mathrm{Cd}$ uptake for each plant.

The results from Fig. 4-3 show that plants influenced F.IV but not in the same way as the F.III. Use of $0.025 \mathrm{M} \mathrm{NH}_{4}$-EDTA and $1 \mathrm{M} \mathrm{NH}_{4} \mathrm{OAc}(\mathrm{pH}$ 4.6) released substantially more $\mathrm{Cd}$ from both soils grown to maize and flax than from soil without plants (Fig. 4-1). This extractant is able to release organically bound $\mathrm{Cd}$ by solubilizing a proportion of the organic matter. In maize and flax soil, $5 \%$ of the total $\mathrm{Cd}$ was released by $0.025 \mathrm{M} \mathrm{NH4-EDTA}$ and $1 \mathrm{M} \mathrm{NH4OAc}(\mathrm{pH} 4.6)$, reflecting the fact that an amount of organic matter could have been added to the soil in the form of organic plant exudates. The composition and amount of root exudates depends on several factors such as plant species, plant age and stage of development, plant growth and presence of microorganisms in the rhizosphere soil. In soils, the organic matter consists of complex polymeric material known as fulvic and humic acids (with high adsorptive capacity) and non-humic substances such as mucilage (polysaccharides), proteins, sugars, organic acids, peptides, amino acids and fats (Egle 2002; Bais et al., 2006; Scheffer/Schachtschabel, 2010 p56-58). These natural complexing agents include root exudates, which can 
reduce mobility (i.e. extractability) due to interaction with $\mathrm{Cd}$ ions. There are several indications that considerable proportions of $\mathrm{Cd}$ are still bound at $\mathrm{pH}$ values between 3 and 4 (Herms and Brümmer, 1984; Brümmer et al., 1986). Unlike spinach and sunflower, F.IV for maize and flax has an important role when assessing the $\mathrm{Cd}$ extraction. With decreasing $\mathrm{pH}$ increases the extraction of $\mathrm{Cd}$ at pH 4.6 only slightly in maize and flax. In this fraction the change was for both plants positive and similar $\left(1.7 \mu \mathrm{mol} \mathrm{Cd} \mathrm{kg}{ }^{-1}\right)$. Obviously, the $\mathrm{Cd}$ uptake could not be affected due to high Cd content bound on F.IV.

To study the connection of the $\mathrm{Cd}$ concentrations present in the soil solution with the different $\mathrm{Cd}$ fractions, the results of sequential extraction were compared with $\mathrm{Cd}$ soil solution concentration obtained from modified displacement method according to Adams (1974). In contrast to Cd reactivity at different solid phase, relatively few publications deal with interaction between $\mathrm{Cd}$ concentration in solid phase and $\mathrm{Cd}$ concentration in solution after growing of plants. Because the plant properties affect the composition of soil solution it is important to evaluate the bioavailability and mobility of $\mathrm{Cd}$ to understand chemical behavior and change of Cd contaminants in soils.

It should be noted that the classification of this extraction scheme as geochemical "mobilisable" and geochemical "easily mobilizable" $\mathrm{Cd}$ is valid only under certain laboratory conditions ( $\mathrm{pH}$, extractans), because $\mathrm{Cd}$ bound in soils under natural environmental conditions can potentially be released into solution from other fractions. The very low $\mathrm{Cd}$ concentration in the soil solution (varied between 0.4-5.8 $\mu \mathrm{M}$ ) represents a further difficulty to achieve a meaningful relationship between mobile $\mathrm{Cd}$ fraction and $\mathrm{Cd}$ in the soil solution (Fig. 4-4 and Tab. 8-3). 
Cadmium is non-specifically adsorbed in the low pH range (3-6) and is thus easier to bring into solution (Zeien 1995; Keller 2000). Brümmer et al. (1986) suggested that, especially in acid soil, the composition of the soil solution might be determined mainly by adsorption-desorption processes of $\mathrm{Cd}$ combined with complexation processes of organic and inorganic ligands. Also only insufficient information exists about the availability of organic $\mathrm{Cd}$ complexes in the solution phase. This lead to different assessments of $\mathrm{Cd}$ relationships related to the enrichment in the soil solution (Gupta and Sinha, 2006).

The fact that the $\mathrm{Cd}$ concentration in soil solution (Chap.2, Fig. 2-3) decreased (Maize, Sunflower), but on the other increased (spinach, flax) could indicate a collection of different $\mathrm{Cd}$ fractions in soil. Unfortunately, anything comparable can be found in the literature, so that this issue need be explored with further research. Under the assumption that $\mathrm{Cd}$ is present in soil solution complexed or chelated, then the effective $\mathrm{Cd}$ soil solution concentration must be much less. The results from the sensitivity analysis (Chap.3) provide very low value of $\mathrm{Cd}$ concentration, so that clear relationships make even more difficult (Fig. 4-5). In the present experiment, the $\mathrm{Cd}$ concentrations in soil solution after addition of 40

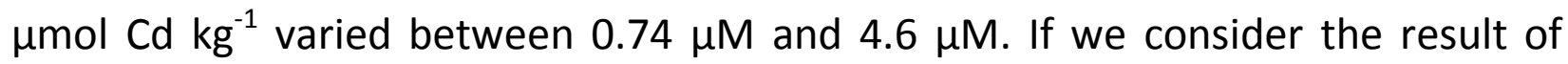
sensitivity analysis then $50 \%$ to $90 \%$ of $\mathrm{Cd}$ in soil solution may be complexed or chelated (Chap. 3, Fig. 3-1, and Tab. 3-3) and the effective concentration of $\mathrm{Cd}^{2+}$ ions in solution will be even lower than 0.15 to $1.6 \mu \mathrm{mol} \mathrm{L}^{-1}$. Sayyari-Zahan et al. (2010) reported that the $\mathrm{Mn}$ concentration in soil solution should be only $3 \%$ to $20 \%$ of $\mathrm{Mn}$ in solution. This method recommend for the sequential extraction of $\mathrm{Cd}$ are based on the assumption that the above-mentioned binding forms exist and depending on $\mathrm{pH}$ enrich a part of $\mathrm{Cd}$ in the soil solution. Release of $\mathrm{Cd}$ into the 
soil solution depends on strong depletion of the soil solution, composition of soil solution, decomposition, oxidation of organic matter and root activity in rhizosphere. The mechanisms by which plants are able to increase (spinach, flax) or decreased (Maize, Sunflower) Cd in to soil solution are high or low root activity as well as high or low influx.

Concluding, the results show that there is no clear relationship between the soil solution $\mathrm{Cd}$ concentration and $\mathrm{Cd}$ levels in any of the $\mathrm{Cd}$ fractions (Fig. 4-3). However, not the entire $\mathrm{Cd}$ in soil is available for plant use. Due to the weak binding of $\mathrm{Cd}$ in the soil and the largest amount of $\mathrm{Cd}$ found in the F.I can be concluded that those enriched the soil solution in higher percentage. However, in multi component-systems like soils it is difficult to assess all possibilities of $\mathrm{Cd}$ binding in solid phase (quantity factor) as well as $\mathrm{Cd}$ in soil solution (intensity factor). Furthermore, the result indicates that the sequential extraction, although operationally defined, cannot provide valuable data for predicting the $\mathrm{Cd}$ availability to plants through the soil solution only in whether the plants can affect the fractions. Further study is required to develop more accurate speciation analysis methods so that well-defined species in soil solution can be determined convincingly. 


\section{SUMMARY}

Plant species differ in $\mathrm{Cd}$ uptake from soil and accumulation in the shoot and therefore the objective of this research was to study to which extent those differences are based on the size of root system, on the $\mathrm{Cd}$ influx, on the growth rate of the shoot and on the proportion of the $\mathrm{Cd}$ taken up that is translocated to the shoot. It was also considered the influence of plants on $\mathrm{Cd}$ availability or solubility in soil and its correlation to $\mathrm{Cd}$ uptake by the plants. For this, maize, sunflower, flax, and spinach were grown on a sandy soil $\left(\mathrm{pH}_{\mathrm{CaCl} 2} 4.5,2.8 \% \mathrm{C}, 5 \%\right.$ clay) with three levels of $\mathrm{Cd}$ addition $\left(0,14\right.$, and $40 \mu \mathrm{mol} \mathrm{kg}{ }^{-1}$ soil). Shoot growth, $\mathrm{Cd}$ concentration, and root growth were determined as well as the $\mathrm{Cd}$ soil solution concentration that was collected through a displacement method.

\section{Shoot growth, shoot $\mathrm{Cd}$ accumulation and $\mathrm{Cd}$ net influx}

At the low $\mathrm{Cd}$ addition of $14 \mu \mathrm{mol} \mathrm{kg}{ }^{-1}$ there was small growth stimulation for maize, sunflower and flax. Of the 4 plants screened, flax and spinach showed severe $\mathrm{Cd}$ toxicity symptoms at $40 \mu \mathrm{mol} \mathrm{Cd} \mathrm{kg}^{-1}$ and thus, were considered to be sensitive to $\mathrm{Cd}$ toxicity in comparison to maize and sunflower. Maize plants grown at $14 \mathrm{Cd} \mu \mathrm{mol} \mathrm{kg} \mathrm{kg}^{-1}$ were approximately similar than those grown at $40 \mathrm{Cd} \mu \mathrm{mol}$ $\mathrm{kg}^{-1}$, even though their shoot $\mathrm{Cd}$ concentrations increased from 1.2 to $8 \mathrm{mg} \mathrm{kg}^{-1}$ SDW, respectively without limiting shoot growth. Sunflower showed shoot Cd concentration of 9.7-25.8 $\mathrm{kg}^{-1}$ SDW while for flax and spinach was up to $66.4 \mathrm{mg}$ $\mathrm{kg}^{-1}$ and $105.1 \mathrm{mg} \mathrm{Cd} \mathrm{kg}^{-1}$, respectively. 
The $\mathrm{Cd}$ shoot influx for sunflower and flax increased linearly with the Cd addition but for spinach and maize, the increase was more than proportional. For a 3-fold increase of $\mathrm{Cd}$ addition (14 to $40 \mu \mathrm{mol} \mathrm{kg}{ }^{-1}$ ) the $\mathrm{Cd}$ influx increased 8-fold (from $0.2 \times 10^{-16}$ to $1.6 \times 10^{-16} \mathrm{~mol} \mathrm{~cm}^{-2} \mathrm{~s}^{-1}$ ) for maize and 6-fold (from $7.5 \times 10^{-16}$ to $42 \times 10^{-16}$ $\mathrm{mol} \mathrm{cm} \mathrm{cm}^{-1}$ ) for spinach. The $\mathrm{Cd}$ shoot influx varied among species at the same $\mathrm{Cd}$ level by a factor of up to 37 .

The shoot $\mathrm{Cd}$ concentration differed among species by a factor of up to 30 . The root area-shoot dry weight ratio (RA / SDW) the highest and lowest value differed by a factor of two to three, spinach having the lowest value which would rather cause a lower $\mathrm{Cd}$ shoot concentration in contrast to what actually was found. The relative shoot growth rate $\left(R G R_{S}\right)$ varied by a factor of maximum of 1.7. $R G R_{S}$ of maize and sunflower was higher than in spinach and flax, irrespective of the level of $\mathrm{Cd}$ addition. The proportion of $\mathrm{Cd}$ translocated to shoot varied in the low (14 $\mu \mathrm{mol} \mathrm{Cd} \mathrm{kg}{ }^{-1}$ ) and high ( $40 \mu \mathrm{mol} \mathrm{Cd} \mathrm{kg}^{-1}$ ) addition from $60 \%$ to $70 \%$ in the less sensitive species and from $70 \%$ to $85 \%$ in the more sensitive. Spinach, the most sensitive species, always showed the highest translocation rate. However, the variation of $60 \%$ to $85 \%$ could not explain the variation of shoot $\mathrm{Cd}$ concentration by a factor of about 10 to 30 . Similarly, the variation of the root-shoot ration and the relative shoot growth rate had less influence and could not explain the variation in shoot $\mathrm{Cd}$ concentration. It was mostly the $\mathrm{Cd}$ influx that varied by a factor of up to 30 which determined the different $\mathrm{Cd}$ concentration in the shoot.

\section{Effect of plants on Cd concentration in soil solution and Cd influx}

Only the $\mathrm{Cd}$ net influx varied parallel to the shoot $\mathrm{Cd}$ concentration, i.e. the $\mathrm{Cd}$ influx was the major factor responsible for the different $\mathrm{Cd}$ accumulation in the 
shoot. Even though spinach had a smaller RA / SDW and a lower RGRs, it achieved a higher shoot $\mathrm{C} d$ concentration because it achieved a 26 times higher $\mathrm{Cd}$ influx than maize. The lower shoot $\mathrm{Cd}$ concentration of maize was attributed to the lower influx. Cadmium influx depends on the uptake kinetics expressed by the root absorbing power, $\alpha$, which is the slope of the almost linear portion of the uptake isotherm in the lower concentration range and the effect of the root on $\mathrm{Cd}$ activity (i.e. the effective $\mathrm{Cd}$ concentration) in the soil solution. Plant growth changed $\mathrm{Cd}$ concentration in soil solution. The $\mathrm{Cd}$ concentration in soil solution significantly decreased after the growth of maize, sunflower, and spinach at the low $\mathrm{Cd}$ addition. For example, $\mathrm{Cd}$ concentration was decreased by about $65 \%$ after the growth of maize and by about $41 \%$ after the growth of sunflower compared to the control. After the growth of flax, the soil solution concentration of $\mathrm{Cd}$ was $84 \%$ higher than the control. At the high $\mathrm{Cd}$ addition $\left(40 \mu \mathrm{mol} \mathrm{Cd} \mathrm{kg}^{-1}\right)$ also spinach increased $\mathrm{Cd}$ soil solution concentration but much less than flax. This shows that plants affected $\mathrm{Cd}$ availability in soil, in some cases decreasing in other cases increasing $\mathrm{C}_{\mathrm{Li}}$ i.e. immobilizing or solubilizing $\mathrm{Cd}$. However, these changes in $\mathrm{C}_{\mathrm{Li}}$ were not enough to explain differences in $\mathrm{Cd}$ influx. Shoot $\mathrm{Cd}$ influx was linearly related to $\mathrm{Cd}$ concentration in soil solution that was found after the plant had grown in the soil and for maize, sunflower and flax adjusted to about the same line with a slope of around $2.5 \times 10^{-7} \mathrm{~cm} \mathrm{~s}^{-1}$ while spinach showed a clearly, 5 times, higher slope of $13.6 \times 10^{-7} \mathrm{~cm} \mathrm{~s}^{-1}$.

\section{Description of Cd influx by a deterministic model}

Further explanations for the different $\mathrm{Cd}$ influx were sought by using mechanistic modeling of $\mathrm{Cd}$ uptake from soil comparing the simulated $\mathrm{Cd}$ influx with the measured Cd influx. The model NST 3.0 uses soil and plant parameters to calculate 
as well as the $\mathrm{Cd}$ concentration distribution around the root, i.e. $\mathrm{Cd}$ dynamics in the rhizosphere. The model assumes that Cd transport to the root is by mass flow and diffusion and that the uptake into the root follows Michaelis-Menten kinetics. For $\mathrm{Cd}$ we used the root absorbing power, $\alpha$, which approximates the uptake isotherm in the low concentration range. These calculations will help to understand why plants differ in their $\mathrm{Cd}$ accumulation. The model over-predicted $\mathrm{Cd}$ influx in all plants. For maize, it was up to 10 times and for flax 7 times, for sunflower 4.7 times whereas for spinach it was only 1.6. Therefore, sensitivity analysis for $\alpha$, and $\mathrm{C}_{\mathrm{Li}}$ was conducted in order to find which parameter might have been wrongly estimated or influenced by plants in the rhizosphere. In the sensitivity analysis, stepwise-reduced values of $\mathrm{C}_{\mathrm{Li}}$ and $\alpha$ were used.

The sensitivity analysis for $C_{\mathrm{Li}}$ showed that by decreasing the value down to $10 \%$ of the original value got $100 \%$ prediction of measured $\mathrm{Cd}$ influx of maize and the $\mathrm{C}_{\mathrm{Li}}$ decreased only by $0.019 \mu \mathrm{M}$. For spinach, the same was achieved by decreasing $\mathrm{C}_{\mathrm{Li}}$ down to $63 \%$ of the original value and according to the model calculations, decreased solution $\mathrm{Cd}$ concentration at the root surface to $0.22 \mu \mathrm{M}$ as compared to $0.019 \mu \mathrm{M}$ for maize after 14 days of uptake. This shows that the soil is able to transport $\mathrm{Cd}$ to the root surface but maize cannot achieve a higher influx at this lower Cd concentration in comparison to spinach.

On the other hand, when decreasing the root absorbing power ( $\alpha$ value) of maize down to $10 \%$ of the original value caused an increased $\mathrm{Cd}$ concentration at the root surface from $0.22 \mu \mathrm{M}$ to $0.24 \mu \mathrm{M}$ because transport by mass flow exceeded Cd influx. In this case, limiting factor for Cd uptake was not soil Cd transport but uptake kinetics, i.e. $\alpha$ value. For spinach, calculated $\mathrm{Cd}$ influx was equal to measured $\mathrm{Cd}$ influx after decreasing the root absorbing power down to $54 \%$ but in 
contrast to maize the $\mathrm{Cd}$ concentration at the root surface decreased from 0.48 $\mu \mathrm{M}$ to $0.46 \mu \mathrm{M}$. The root were able to decrease the concentration further $\left(C_{L}=\right.$ $0.46 \mu \mathrm{M})$, thereby creating a small concentration gradient to allow diffusive transport of $\mathrm{Cd}$ towards the root. The results of sensitivity analysis showed that the Cd uptake without consideration of other not well-defined processes, such as immobilization or complexation in soil solution (i.e. effective concentration), was not explained. The high degree of sensitivity to $\mathrm{C}_{\mathrm{Li}}$ and $\alpha$ value for maize indicate that uptake kinetics ( $\alpha$ value) was the major limiting factor for uptake and not $\mathrm{Cd}$ mobility through the soil towards the root. The amount of overestimation indicates the dimension of o possible complexation of $\mathrm{Cd}$ in soil solution. Maize and spinach have different uptake kinetics and they possible are able to change the composition of soil solution through root activity.

\section{Plant growth on $\mathrm{Cd}$ binding in soil}

Plants were able to solubilized or immobilized $\mathrm{Cd}$ in soil because they changed $\mathrm{Cd}$ solution concentration resulting in maize and spinach to reduce and flax to increase it. This change will affect the equilibrium of $\mathrm{Cd}$ in soil solution with $\mathrm{Cd}$ fractions in soil or its distribution, and its chemical form in the soil. This was

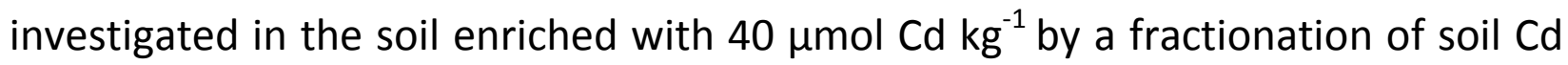
with a sequential extraction. The seven binding fractions of $\mathrm{Cd}$ are operationally defined by an extraction sequence that follows the order of increasing acidity with extractants of different complexing and redox properties. These fractions are: mobile fraction (F.I), easily mobilizable fraction (F.II), occluded in Mn oxides bound fraction(F.III), organically bound fraction (F.IV), occluded in poorly crystalline Fe oxide bound fraction (F.V), occluded in crystalline Fe oxides bound fraction (F.VI) and residual fraction (F.VII). 
In soil without plants, Cd was mostly concentrated in F.I $\left(14.3 \mu \mathrm{mol} \mathrm{Cd} \mathrm{kg}{ }^{-1}\right)$ and

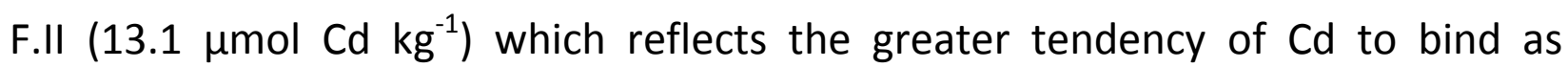
exchangeable in this soil, although it was also present in other fractions. The $\mathrm{Cd}$ bound in F.III was $9.6 \mu \mathrm{mol} \mathrm{Cd} \mathrm{g^{-1 }}(22 \%)$ and $\mathrm{Cd}$ bound to organic matter in F.IV was lower $\left(5 \mu \mathrm{mol} \mathrm{kg}{ }^{-1}\right.$ or $\left.10 \%\right)$. The remaining fractions represented less than $5 \%$.

Fraction I (mobile fraction): all plants decreased the content of this fraction. This decrease of $1.6 \mu \mathrm{mol} \mathrm{kg}{ }^{-1}$ to $2.7 \mu \mathrm{mol} \mathrm{kg}{ }^{-1}$ was more than $\mathrm{Cd}$ uptake, which varied from $0.5 \mu \mathrm{mol} \mathrm{kg}{ }^{-1}$ to $2.2 \mu \mathrm{mol} \mathrm{kg}{ }^{-1}$.

Fraction II (easily mobilizable): In F.II recorded a negative change of $\mathrm{Cd}$ in the soil grown to flax $\left(1.7 \mu \mathrm{mol} \mathrm{kg}{ }^{-1}\right)$ whereas in maize $\left(3.5 \mu \mathrm{mol} \mathrm{kg}{ }^{-1}\right)$ and spinach (4 $\mu \mathrm{mol}$ $\left.\mathrm{kg}^{-1}\right)$ is noticed a positive change indicating a change in the $\mathrm{Cd}$ distribution, in the soil due to plant growth.

Fraction III (occluded in Mn oxides): There was a significant reduction in sunflower $\left(3.7 \mu \mathrm{mol} \mathrm{kg}{ }^{-1}\right)$ and a little in spinach $\left(2.5 \mu \mathrm{mol} \mathrm{kg}{ }^{-1}\right)$. F.III could have covered $\mathrm{Cd}$ uptake of sunflower $\left(0.8 \mu \mathrm{mol} \mathrm{kg}{ }^{-1}\right)$ and spinach $(2.2 \mu \mathrm{mol} \mathrm{kg})$. The negative change in the maize $\left(0.6 \mu \mathrm{mol} \mathrm{kg}{ }^{-1}\right)$ was almost similar to the $\mathrm{Cd}$ uptake. The $\mathrm{Cd}$ content in flax was not change and had no effect on Cd uptake.

Fraction IV (organically bound fraction): In F.IV the Cd content increased clearly in maize and flax $\left(1.7 \mu \mathrm{mol} \mathrm{Cd} \mathrm{kg}^{-1}\right)$ while in spinach the increase was very low and sunflower had no effect.

This shows that plants change the binding of $\mathrm{Cd}$ in soil in a different manner, depending on the plants species. Plants also changed $\mathrm{Cd}$ in soil solution; it varied form $0.5 \mu \mathrm{M}$ with maize to $5.8 \mu \mathrm{M}$ with flax. The fact that the $\mathrm{Cd}$ concentration in 
soil solution decreased (Maize, Sunflower), but on the other increased (spinach, flax) might indicate different a distribution of $\mathrm{Cd}$ fractions in soil. However, there was no relationship between changes in $\mathrm{Cd}$ fraction and changes of $\mathrm{Cd}$ concentration in soil solution. Also only insufficient information exists about the availability of organic $\mathrm{Cd}$ complexes in the solution phase. Under the assumption that $\mathrm{Cd}$ is present in soil solution complexed or chelated, then the effective $\mathrm{Cd}$ soil solution concentration would be much lower. Based on the results from the sensitivity analysis, we assume a very low value of $\mathrm{Cd}$ concentration (i.e. effective Cd concentration) and/or a different $\alpha$ value. 


\section{ZUSAMMENFASSUNG}

Pflanzenarten unterscheiden sich in der Cd-Aufnahme aus dem Boden und in der Cd-Akkumulation im Spross und somit das Ziel dieser Studie war zu untersuchen, inwieweit diese Unterschiede auf der Größe des Wurzelsystems, auf dem Cd-Influx, auf der Wachstumsrate des Sprosses und/oder der Translokation des Cd von der Wurzel in den Spross basieren. Es wurde auch der Einfluss von Pflanzen auf die Cd-Verfügbarkeit bzw. die Löslichkeit im Boden und ihre Beziehung zur Cd-Aufnahme durch die Pflanzen betrachtet. Für diesen Vorhaben wurde Mais, Sonnenblumen, Öllein, und Spinat auf einem sandigen Boden $\left(\mathrm{pHCaCl}_{2} 4,5,2,8 \%\right.$ C, 5\% Ton) mit drei Cd-Stufen $\left(0,14\right.$ und $40 \mu \mathrm{mol} \mathrm{kg}{ }^{-1}$ Boden) angebaut. Sprossund Wurzelwachstum und Cd-Gehalte wurden bestimmt sowie die Cd-Konzentration in der Bodenlösung, die durch eine Verdrängung gewonnen wurde

\section{Sprosswachstum, Cd-Akkumulation im Spross und Cd-Influx}

Bei der niedrigen Cd-Zufuhr von $14 \mu \mathrm{mol} \mathrm{kg}^{-1}$ gab es eine geringe Wachstumsstimulation für Mais, Sonnenblumen und Öllein. Von den 4 untersuchten Pflanzen, zeigten Öllein und Spinat schwere Cd-Toxizitätsymptome

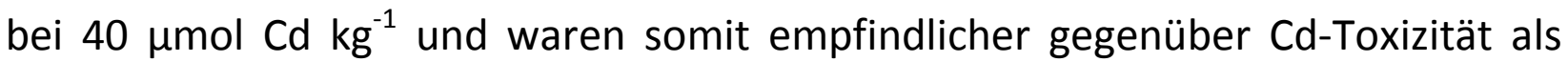
Mais und Sonnenblume. Das Wachstum von Mais auf $14 \mathrm{Cd} \mu \mathrm{mol} \mathrm{kg}^{-1}$ war ähnlich mit dem bei $40 \mathrm{Cd} \mu \mathrm{mol} \mathrm{kg}{ }^{-1}$, obwohl die Cd-Konzentration im Spross von 1,2 mg $\mathrm{kg}^{-1}$ auf $8 \mathrm{mg} \mathrm{kg}{ }^{-1} \mathrm{TM}$ erhöht wurde. Bei Sonnenblume erhöhte sich die Cd-Konzentration im Spross von 9,7 $\mathrm{mg} \mathrm{kg}^{-1}$ bis $25,8 \mathrm{mg} \mathrm{kg}^{-1} \mathrm{TM}$ während sie für Öllein und Spinat auf 66,4 $\mathrm{mg} \mathrm{kg}^{-1}$ bzw. 105,1 $\mathrm{mg} \mathrm{kg}^{-1} \mathrm{TM}$ anstieg. 
Der Cd-Sprossinflux von Sonnenblume und Öllein erhöhte sich linear mit steigender Cd-Zufuhr aber für Spinat und Mais war der Anstieg überproportional. Für eine 3-fach erhöhte Cd-Zufuhr (von $14 \mu \mathrm{mol} \mathrm{kg}{ }^{-1}$ auf $40 \mu \mathrm{mol} \mathrm{kg}{ }^{-1}$ ) im Boden stiegt der Cd-Sprossinflux bei Mais 8-fach (von $0,2 \times 10^{-16} \mathrm{~mol} \mathrm{~cm}^{-2} \mathrm{~s}^{-1}$ auf $1,6 \times 10^{-16}$ mol cm $\mathrm{cm}^{-1}$ ) und 6 -fach (von $7,5 \times 10^{-16} \mathrm{~mol} \mathrm{~cm}^{-2} \mathrm{~s}^{-1}$ auf $42 \times 10^{-16} \mathrm{~mol} \mathrm{~cm}^{-2} \mathrm{~s}^{-1}$ ) für Spinat an. Der Cd-Sprossinflux variierte zwischen den Pflanzenarten innerhalb derselben Cd-Stufe um einen Faktor von bis zu 37.

Die Cd-Konzentration im Spross variierte zwischen den Pflanzenarten um einen Faktor von bis zu 30. Das Wurzeloberfläche/Spross-Verhältnis (WSV) variierte um den Faktor zwischen 2 und 3, wobei Spinat den niedrigsten Wert hatte. Ein niedriger Wert würde eher zu einer niedrigeren Cd-Konzentration im Spross führen, aber stattdessen war der Wert größer. Die relative Wachstumsrate des Sprosses $\left(R G R_{S}\right)$ variierte um einen Faktor von maximal $1,7 . R G R_{S}$ von Mais und Sonnenblumen war höher als in Spinat und Öllein, unabhängig von der Höhe der Cd-Zufuhr. Der translozierte Cd-Anteil im Spross variierte zwischen der niedrigen (14 $\left.\mu \mathrm{mol} \mathrm{Cd} \mathrm{kg}{ }^{-1}\right)$ und der höchste Cd-Zufuhr (40 $\left.\mu \mathrm{mol} \mathrm{Cd} \mathrm{kg}{ }^{-1}\right)$ um 60\% - 70\% bei den weniger empfindlichen Pflanzenarten und um $70 \%-85 \%$ bei den empfindlichen Pflanzenarten. Spinat, der empfindlichsten Pflanzenart, zeigte immer die höchste Translokationsrate. Die Variation von $60 \%$ bis $85 \%$ könnte allerdings nicht den Unterschied in der Cd-Konzentration im Spross bei einem Faktor von etwa 10 bis 30 erklären. Ebenso hatte die Variation des Wurzeloberfläche/Spross Verhältnisses und die relative Wachstumsrate des Sprosses weniger Einfluss und konnte nicht die Variation der Cd-Konzentration im Spross erklären. Es war vor allem der Cd-Sprossinflux, der durch einen Faktor von bis zu 30 variierte, und bestimmte damit die Cd-Konzentration im Spross 


\section{Wirkung von Pflanzen auf die Cd-Konzentration in der Bodenlösung und auf den Cd-Sprossinflux}

Nur der Cd-Sprossinflux variierte parallel zu der Cd-Konzentration im Spross, d.h. der Cd-Sprossinflux war der Hauptfaktor für die unterschiedliche Cd-Akkumulation im Spross. Obwohl Spinat ein kleineres WSV und eine niedrige $\mathrm{RGR}_{\mathrm{S}}$ hatte, erzielte er eine höhere Cd-Konzentration im Spross, weil er einen 26-mal höheren Cd-Sprossinflux als Mais hatte. Die niedrigere Cd-Konzentration im Spross von Mais war auf den niedrigeren Cd-Sprossinflux zurückzuführen. Cadmium-Sprossinflux hängt ab von der Aufnahmekinetik ausgedrückt durch die Wurzel-Aufnahmefähigkeit (root absorbing power), $\alpha$, die das Steigungsmaß des fast linearen Teils der Aufnahme-Isotherme im unteren Konzentrationsbereich beschreibt und von der Wurzelwirkung auf die Cd-Aktivität (d.h. die effektive CdKonzentration) in der Bodenlösung. Das Pflanzenwachstum beeinflusste die Cd-Konzentration in der Bodenlösung. Die Cd-Konzentration in der Bodenlösung nahm deutlich nach dem Wachstum von Mais, Sonnenblume, und Spinat bei der niedrigen Cd-Zufuhr ab. Zum Beispiel wurde die Cd-Konzentration in der Bodenlösung $\left(C_{\mathrm{Li}}\right)$ durch Mais um etwa $65 \%$ und durch Sonnenblume um $41 \%$ gegenüber den Kontrolltöpfen erniedrigt. Dagegen war nach Wachstum von Öllein, die $\mathrm{C}_{\mathrm{Li}}$ um 84\% erhöht. Bei der hohen Cd-Zufuhr $\left(40 \mu \mathrm{mol} \mathrm{Cd} \mathrm{kg}^{-1}\right)$ waren auch bei Spinat $C_{\mathrm{Li}}$ erhöht aber deutlich weniger als bei Öllein. Dies zeigt, dass die Pflanzen die Cd-Verfügbarkeit im Boden beeinflussten, in einigen Fällen erniedrigten sie in anderen Fällen erhöten sie $C_{L i}$ d.h. die Pflanzen immobilisierten bzw. lösten das $\mathrm{Cd}$ im Boden. Diese Änderungen von $\mathrm{C}_{\mathrm{Li}}$ waren allerdings nicht genug, um die Unterschiede im Cd-Sprossinflux zu erklären. Der Cd-Sprossinflux war linear korreliert mit der Cd-Konzentration in der Bodenlösung, die gefunden 
wurde, nachdem die Pflanzen im Boden gewachsen waren. Für Mais, Sonnenblumen und Öllein war das Steigungsmaß dieser linearen Beziehung ähnlich hoch, von rund $2,5 \times 10^{-7} \mathrm{~cm} \mathrm{~s}^{-1}$, während bei Spinat war sie mit $13,6 \times 10^{-7}$ $\mathrm{cm} \mathrm{s}^{-1}$ um den Faktor 5 deutlich höher.

\section{Beschreibung von Cd-Sprossinflux durch ein deterministisches Modell}

Weitere Erklärungen für den unterschiedlichen Cd-Sprossinflux wurden mit Hilfe von mechanistischer Modellierung den Cd-Aufnahme aus dem Boden gesucht, indem der simulierte Cd-Sprossinflux mit dem gemessenen Cd-Sprossinflux verglichen wurde. Das Modell NST 3.0 verwendet Boden- und Pflanzenparameter um sowohl den Cd-Sprossinflux zu berechnen als auch die Cd-Konzentrationsverteilung um die Wurzel, d.h. Cd-Dynamik in der Rhizosphäre zu verzeichnen. Das Modell setzt voraus, dass Cd-Transport an die Wurzel durch Massenfluss und Diffusion erfolgt und dass die Aufnahme in die Wurzel mit der Michaelis-Menten-Kinetik beschrieben wird. Für $\mathrm{Cd}$ wurde die WurzelAufnahmefähigkeit (root absorbing power), $\alpha$, verwendet, welche sich die Aufnahme-Isotherme im niedrigen Konzentrationsbereich annähert. Diese Berechnungen könnten zusätzliche Information liefern, warum die Pflanzen sich in ihrer Cd-Akkumulation im Spross unterschieden. Das Modell überschätzte den Cd-Sprossinflux bei allen Pflanzenarten. Bei Mais war es bis zu 10-mal, für Öllein 7-mal und für Sonnenblumen 4,7-mal während es für Spinat nur 1,6 war. Daher wurde eine Sensitivitätsanalyse für $\alpha$ und $\mathrm{C}_{\mathrm{Li}}$ durchgeführt, um herauszufinden, welche von den eingegebenen Parametern es gewesen sein könnten, die falsch eingeschätzt oder von den Pflanzen in der Rhizosphäre beeinflusst waren. In der Sensitivitätsanalyse wurden stufenweise die Werte von $\mathrm{C}_{\mathrm{Li}}$ und $\alpha$ gesenkt. Die Sensitivitätsanalyse zeigte, dass $C_{\mathrm{Li}}$ bei Mais bis auf $10 \%$ und bei Spinat bis auf $63 \%$ 
des ursprünglichen Wertes gesenkt werden musste um eine $100 \%$ Übereinstimmung des gemessenen mit dem berechneten Cd-Sprossinflux zu erreichen.

Auf der anderen Seite, wenn die Wurzel-Aufnahmefähigkeit ( $\alpha$-Wert) von Mais auf $10 \%$ des ursprünglichen Wertes gesenkt wurde, verursachte es eine Erhöhung der Cd-Konzentration an der Wurzeloberfläche von 0,22 $\mu \mathrm{M}$ auf 0,24 $\mu \mathrm{M}$, da der Cd-Transport durch Massenfluss den Cd-Sprossinflux überstieg. In diesem wie auch in den anderen Fällen, war der limitierende Faktor für die Cd-Aufnahme nicht der Cd-Transport im Boden sonder die Cd-Aufnahmekinetik, d.h. der $\alpha$-Wert. Für Spinat, der berechnete Cd-Sprossinflux war gleich den gemessenen Cd-Sprossinflux nach Verringerung von $\alpha$-Wert auf $54 \%$, aber im Gegensatz zu Mais die Cd-Konzentration an der Wurzeloberfläche sank von 0,48 $\mu \mathrm{M}$ auf 0,46 $\mu M$. Die Wurzeln konnten die Konzentration weiter verringern $\left(C_{L}=0,46 \mu M\right)$, wodurch ein kleiner Konzentrationsgradient zu diffusiven Cd-Transport in Richtung der Wurzel entstand. Die Ergebnisse der Sensitivitätsanalyse zeigten, dass die Cd-Aufnahme ohne Berücksichtigung andere nicht gut definierte Prozesse, wie z.B. Immobilisierung oder Komplexierung in der Bodenlösung (d.h. effektive Cd-Konzentration) nicht erklärt werden konnten. Die hohe Empfindlichkeit auf $\mathrm{C}_{\mathrm{Li}}$ und $\alpha$-Wert für Mais wiesen darauf hin, dass die Aufnahmekinetik ( $\alpha$-Wert) der limitierende Faktor für die Cd-Aufnahme und nicht die Cd-Mobilität im Boden war. Die Höhe der Überschätzung deutete die Dimension einer möglichen Komplexierung von $\mathrm{Cd}$ in der Bodenlösung an. Mais und Spinat haben unterschiedliche Aufnahmekinetik und sie waren möglicherweise in der Lage, die Zusammensetzung der Bodenlösung durch Wurzelaktivität zu verändern. 


\section{Einfluss des Pflanzenwachstums auf die Cd-Bindung im Boden}

Pflanzen konnten Cd im Boden lösen oder immobilisieren, weil Mais und Spinat die Cd-Konzentration in der Bodenlösung reduziert haben hingegen Öllein sie erhöht hat. Diese Veränderung könnte auf das Gleichgewicht von $\mathrm{Cd}$ in der Bodenlösung mit den Cd-Fraktionen im Boden oder dessen Verteilung und die chemische Form im Boden zurückgeführt werden. Dies wurde im Boden mit 40 $\mu \mathrm{mol} \mathrm{Cd} \mathrm{kg}^{-1}$ durch eine Fraktionierung mit einer sequentiellen Cd-Extraktion untersucht. Die sieben Cd-Fraktionen sind operativ durch eine Extraktionsfolge definiert, da die Extraktionsmittel zunehmende Acidität und/oder unterschiedliche Komplexierungs- und Redoxeigenschaften aufweisen. Diese Fraktionen sind: mobile Fraktion (FI), leicht mobilisierbare Fraktion (F.II), in Mn-Oxiden okkludierte Fraktion (F.III), organisch gebundene Fraktion (F.IV), in schlecht kristallinen Fe-Oxiden okkludiert Fraktion (F.V ), in kristallinen Fe-Oxide okkludiert Fraktion (F.VI) und Residualfraktion (F. VII).

In Bodenproben ohne Pflanzen, Cd war meist in F.I $\left(14,3 \mu \mathrm{mol} \mathrm{Cd} \mathrm{kg}{ }^{-1}\right)$ und F. II $\left(13,1 \mu \mathrm{mol} \mathrm{Cd} \mathrm{kg}{ }^{-1}\right)$ konzentriert, dass die größeren Neigung von Cd reflektiert als austauschbar im Boden gebunden zu sein, wobei es auch in anderen Fraktionen vorhanden war. Der Cd-Anteil in F.III betrug 9,6 $\mu \mathrm{mol} \mathrm{Cd} \mathrm{kg}{ }^{-1}(22 \%)$ und in F. IV war niedriger (5 $\mathrm{\mu mol} \mathrm{kg}{ }^{-1}$ oder $\left.10 \%\right)$. Auf die übrigen Fraktionen entfielen weniger als $5 \%$.

Fraktion I (mobile Fraktion): alle Pflanzen senkten den Cd-Gehalt dieser Fraktion. Dieser Rückgang von $1,6 \mu \mathrm{mol} \mathrm{kg}{ }^{-1}$ bis $2,7 \mu \mathrm{mol} \mathrm{kg}{ }^{-1}$ war mehr als die Cd-Aufnahme, die von $0,5 \mu \mathrm{mol} \mathrm{kg}{ }^{-1}$ bis $2,2 \mu \mathrm{mol} \mathrm{kg}{ }^{-1}$ variierte. 
Fraktion II (leicht mobilisierbar): In F.II verzeichnete eine negative Veränderung von Cd-Gehalt in Bodenproben mit Öllein $\left(1,7 \mu \mathrm{mol} \mathrm{kg}{ }^{-1}\right)$ während die mit Mais $\left(3,5 \mu \mathrm{mol} \mathrm{kg}{ }^{-1}\right)$ und Spinat $\left(4 \mu \mathrm{mol} \mathrm{kg}{ }^{-1}\right)$ eine positive Veränderung zeigte. Dies zeigt eine Veränderung in der Cd-Verteilung im Boden durch das Pflanzenwachstum an.

Fraktion III (okkludiert in Mn-Oxide): Es gab eine signifikante Reduktion von Cd-Gehalt bei Sonnenblume $\left(3,7 \mu \mathrm{mol} \mathrm{kg}{ }^{-1}\right)$ und ein wenig bei Spinat $(2,5 \mu \mathrm{mol}$ $\left.\mathrm{kg}^{-1}\right)$. F.III könnte die Cd-Aufnahme von Sonnenblumen $\left(0,8 \mu \mathrm{mol} \mathrm{kg}^{-1}\right)$ und Spinat $\left(2,2 \mu \mathrm{mol} \mathrm{kg}{ }^{-1}\right)$ gedeckt haben. Die negative Veränderung bei Mais $\left(0,6 \mu \mathrm{mol} \mathrm{kg}{ }^{-1}\right)$ war fast gleich wie die Cd-Aufnahme. Der Cd-Gehalt bei Öllein war nicht verändert und könnte keinen Einfluss auf Cd-Aufnahme haben.

Fraktion IV (organisch gebundene Fraktion): In F. IV der Cd-Gehalt stieg deutlich

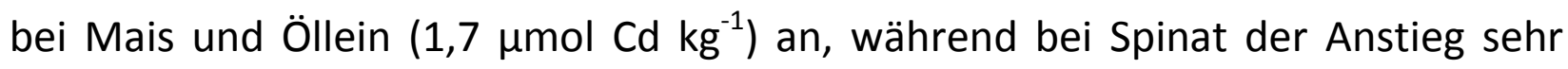
gering war und bei Sonnenblumen keine Wirkung hatte.

Dies zeigt, dass Pflanzen die Cd-Bindung im Boden in unterschiedlicher Weise, je nach Pflanzenarte verändern können. Pflanzen haben auch die Cd-Konzentration in der Bodenlösung verändert, wobei die Variation von $0,5 \mu \mathrm{M}$ bei Mais bis auf 5,8 $\mu \mathrm{M}$ bei Öllein schwankte. Die Tatsache, dass die Cd-Konzentration in der Bodenlösung (Mais, Sonnenblumen) abgenommen, aber auf der anderen erhöht (Spinat, Öllein) wurde, könnte auf eine unterschiedliche Verteilung von CdFraktionen im Boden hindeuten. Es gab jedoch keinen Zusammenhang zwischen Veränderungen in der Cd-Fraktion und Veränderungen der Cd-Konzentration in der Bodenlösung. Ebenfalls nur unzureichende Informationen liegen über die Verfügbarkeit von organischen Cd-Komplexen in der Lösungsphase vor. Unter der 
Annahme, dass $\mathrm{Cd}$ in der Bodenlösung komplexiert oder chelatisiert wäre, dann wäre die effektive Cd-Konzentration in der Bodenlösung viel niedrigere. Basierend auf den Ergebnissen der Sensitivitätsanalyse, nehmen wir einen sehr niedrigen Wert der Cd-Konzentration in der Bodenlösung (d.h. effektive Cd-Konzentration) und / oder einen niedrigeren $\alpha$-Wert an. 


\section{REFERENCES}

Adams, F. (1974): Soil solution. In E. W. Carson: The Plant Root and its Environment. Univ. of Virginia Charlottesville, p. 441-481.

Alcantara, E., Romera, F. J., Canete, M., De La Gaurdia, M. D., (1994): Effects of heavy matals on both induction and fuction of root Fe (III) reductase in Fedeficient cucumber (Cucumis sativus L.) palnts. J. Exp. Bot. 45, 1893-1898.

Azad, A. S., Sekhon, G. S. and Arora, B. R., (1986): Distribution of Cadmium Nickel and Cobalt in Sewage Water Irrigated Soils. J. Indian Soc. Soil Sci. 34, 619-621.

Backes, C. A., McLaren, R. G., Rate W. A. and Swift, R. S. (1995): Kinetics of Cadmium and Cobalt Desorption from Iron and Manganese Oxides. Soil Sci. Soc. Am. J. 59:778-785.

Bais, H. P., Weir, T. L., Perry, L. G., Gilroy, S. and Vivanco, J. M. (2006): The Role of Root Exudates in Rhizosphere Interactions with Plants and Other Organisms. Annu. Rev. Plant Biol. 2006.

Baker A. J. M., McGrath S., P., Reeves R. D., Smith J. A. C. (2000): Metal hyperaccumulator plants: a review of the ecology and physiology of a biochemical resource for phytoremediation of metal-polluted soils. In Phytoremediation of Contaminated Soil and Water. Eds. N Terry, G Bañuelos and J Vangronsveld. pp 85-107. Lewis Publishers, Boca Raton, FL, USA.

Barber S. A., (1962): Diffusion and mass-flow concept of soil nutrient availability. Soil Sci. 93:39-49.

Barber, S. A., Cushman, J. H. (1981): Nitrogen uptake model for agronomic crops, in Ishandar, J. K. (ed.): Modelling Waste Water Renovation - Land Treatment. Wiley Inter-Science, New York, pp. 382-409.

Barcelo, J., Poschenrieder, C.H. (1990): Plant water relations as affected by heavy metal stress: a review. Journal of Plant Nutrition 13, 1-37.

Barraclough, P B., Tinker P B. (1981): The determination of ionic diffusion coefficients in field soils. I: Diffusion coefficients in sieved soils in relation to water content and bulk density. J. Soil Sci. 32, 225-236. 
Bergmann, W. (1993): Ernährungsstörungen bei Kulturpflanzen. 3. Aufl. SpektrumAkademischer VIg., Stuttgart. pp355 - 361.

Bhadoria, P.S., El Dessougi, H., Liebersbach, H., Claassen, N., (2004): Phosphorus uptake kinetics, size of root system and growth of maize and groundnut in solution culture. Plant Soil 262, 327-336.

Bhadoria, S. P., Steingrobe, B., Claassen, N. \& Liebersbach, N. (2002) Phosphorus efficiency of wheat and sugar beet seedlings grown in soils with mainly calcium, or iron and aluminium phosphate. Plant and Soil 246: 41-52.

Brown S L, Chaney R L, Angle J S and Baker A J M (1994): Phytoremediation potential of Thlaspi caerulescens and Bladder Campion for zinc and cadmiumcontaminated soil. J. Environ. Qual. 23, 1151-1157.

Brümmer, G. und Herms, U. (1983): In: Ulrich, B. und Pankrath, J. (eds.): Effects of accumulation of air pollutants in forrest ecostystems. D. Reidel Publishing Company, pp. 233-234.

Brümmer, G., Tiller, K.G., Herms U., and Clayton, P.M. (1983): Adsorptiondesorption and/or precipitation-dissolution processes of zinc in soils. Ceoderma 31, 337-354.

Brümmer, G.W., G. Welp, F. Liebe und J. Keppler. (1998): Mobile und mobilisierbare Fraktionen anorganischer Schadstoffe in Böden. DVWKSchriften 122: 403-419.

Brümmer, G.W., Gerth J. and Herms U. (1986): Heavy metal species, mobility and availability in soil. Z. Pflanzenernähr. Bodenk. 149. 382-398.

Buhse, J. (1992): Wirkung der Wurzelraumtemperatur auf das Phosphataneignungs-vermögen von Pflanzen und die Phosphatverfügbarkeit im Boden. Dissertation Universität Göttingen, Germany.

Cabrera, D., Young, S. D. and Rowell, D. L. (1988): The toxicity of cadmium to barley plants as affected by complex formation with humic acid. Plant and Soil 105, 195204.

Chao, T.T. (1972): Selective dissolution of manganese oxides from soils and sediments with acidified hydroxylamine hydrochloride, Soil Sci. Soc. Am. Proc. 36, pp. 764-768.

Cieslinski, K.C.J. Van Rees, A.M. Szmigielska, G.S.R. Krishnamurti and P.M. Huang (1998): Low-molecular-weight organic acids in rhizosphere soils of durum 
wheat and their effect on cadmium bioaccumulation. Plant and Soil 203: 109117.

Claassen, N. (2006): The significance of uptake kinetics for nutrient uptake from soil: a theoretical approach. $1^{\text {st }}$ Joint Conference of The German Society for Plant Nutrition-DGP (annual Meeting), Hohenheim University, Stuttgart, Germany.

Claassen, N., (1990\&1994): Nährstoffaufnahme höherer Pflanzen aus dem Boden Ergebnis von Verfügbarkeit und Aneignungsvermögen. 2. Auflage Severin Verlag Göttingen.

Claassen, N., and Steingrobe. B. (1999): Mechanistic simulation models for a better understanding of nutrient uptake from soil, in Rengel, Z. (ed.): Mineral Nutrition of Crops - Fundamental mechanisms and implications. Food Products Press, New York, pp. 327-367.

Claassen, N., Barber, S. A. (1976): Simulation model for nutrient uptake from soil by a growing plant root systems. Agro. J. 68, 961-964.

Claassen, N., Steingrobe. B. (1999): Mechanistic simulation models for a better understanding of nutrient uptake from soil, in Rengel, Z. (ed.): Mineral Nutrition of Crops - Fundamental mechanisms and implications. Food Products Press, New York, pp. 327-367.

Claassen, N., Syring, K.M., Jungk, A., (1986): Verification of a mathematical model by simulating potassium uptake from soil. Plant Soil 95, 209-220.

Dessougi HI, Claassen N, Steingrobe B (2002): Potassium efficiency mechanisms of wheat, barley and sugar beet grown on a $\mathrm{K}$ fixing soil under controlled conditions. J Plant Nutr Soil Sci 165(6):732-737.

di Toppi SL, Gabbrielli R (1999) Response to cadmium in higher plants. Environ Exp Bot 41: $105-130$.

Domeyer, K (2005): An- und Abreicherung von Schwermetallen in der Rhizosphäre und deren Entzug durch landwirtschaftliche Kulturpflanzen unter besonderer Berücksichtigung der Aspekte einer Phytosanierung. Inaugural-Dissertation, Bonn.

Dong, J., Wu, F., and Zhang, G. (2005): Effect of cadmium on growth and photosynthesis of tomato seedlings. J Zhejiang Univ Sci B. 6(10): 974-980. 
Dunbar, K.R., M.J. McLaughlin and R.J. Reid. (2003): The uptake and partitioning of cadmium in two cultivars of potato (Solanum tuberosum L.). J. Experimental Botany, 54: 349-354.

Egle, K. (2002): Untersuchungen zum Phosphor-, Kupfer-, Zink- und CadmiumAneignungsvermögen von drei Lupinenarten und Weidelgras unter Berücksichtigung wurzelbürtiger organischer Säuren. Dissertation, Univ. Göttingen, Shaker-Verlag, Aachen.

Epstein 1972 Epstein E. (1972): Mineral nutrition of plants: Principles and Perspectives Wiley, New York.

Eriksson, J., and M. Söderström, (1996): Cadmium in soil and winter wheat grain in southern Sweden. I. Factors influencing $\mathrm{Cd}$ levels in soils and grains. Acta Agric. Scand. sec. B. Soil Sci. 46:240-248.

Fischer, W. R., H. Flessa and G. Schaller (1989): pH values und redox potentials in microsites of the rhizosphere. Z. Pflanzenernähr. Bodenkd. 152, 191-195.

Flagella, Z., Rotunno, T., Tarantino, E., Caterina, R. Di. and Caro, A. De. (2002): Changes in seed yield and oil fatty acid composition of high oleic sunflower (Helianthus annuus L.) hybrids in relation to the sowing date and the water regime, European Journal of Agronomy, Volume 17, Issue 3, Pages 221-230.

Flessa, H und R. Fisher, W. R. (1992): Redoxprozesse in der Rhizosphare von Landund Sumpfpflanzen. Z. Pflanzenernähr. Bodenk. 155, 373-378 .

Gerke, J. (1995): Chemische Prozesse der Nährstoffmobilisierung in der Rhizosphäre und ihre Bedeutung für den Übergang vom Boden in die Pflanze. Habil.-Schr., Cuvillier Verlag, Göttingen.

Gerth, J., Schimming, C. G. und Brümmer, G. (1981): Einfluss der ChloroKomplexbildung auf Löslichkeit und Adsorption von Nickel, Zink und Cadmium. Mitteilung. Dtsch. Bodenkundl. Gesellsch. 30, 19-30.

Grant, C. A., Buckley, W. T., Bailey, L. D., Selles, F. (1998): Cadmium accumulation in crops. Can J Plant Sci. 78 (1): 1-17.

Guo, Y. and Marschner, H., (1995): Uptake, distribution, and binding of cadmium and nickel in different plant species. J. Plant Nutr. 18(12), 2691-2706.

Gupta A. K. and Sinha, S (2006): Chemical fractionation and heavy metal accumulation in the plant of Sesamum indicum (L.) var. T55 grown on soil 
amended with tannery sludge: Selection of single extractants. Chemosphere, Volume 64, Issue 1, Pages 161-173

Gupta, S.K. and Aten, C. (1993): Comparison and evaluation of extraction media and their suitability in a simple model to predict the biological relevance of heavy metal concentrations in contaminated soils, International Journal of Environmental Analytical Chemistry 51, pp. 25-46.

Haag-Kerwer A, Schafer HJ, Heiss S, Walter C, Rausch T. (1999): Cadmium exposure in Brassica juncea causes a decline in transpiration rate and leaf expansion without effect on photosynthesis. J Exp Bot. 50(341):1827-1835. doi: $10.1093 / \mathrm{jxb} / 50.341 .1827$

Haag-Kerwer A, Schäfer HJ, Heiss S, Walter C, Rausch T. (1999): Cadmium exposure in Brassica juncea causes a decline in transpiration rate and leaf expansion without effect on photosynthesis. Journal of Experimental Botany 50, 1827-1835.

Harter, R. D. (1983): Effect of Soil pH on Adsorption of Lead, Copper, Zinc, and Nickel. Soil Sci. Soc. Am. J. 47, 47-51.

Hassan, H. J., Zhang, G., Wu, F., Wel, K. and Chen, Z. (2005): Zinc alleviates growth inhibition and oxidative stress caused by cadmium in rice. J. Plant Nutr. Soil Sci. 168, 255-261.

Helmke, P.A (1999): Chemistry of cadmium in soil solution. In: M.J. McLaughlin and B.R. Singh, Editors, Cadmium in Soils and Plants, Kluwer Academic, Netherlands, pp. 39-64.

Herms, U. und Brümmer, G. (1978): Einfluss organischer Substanzen auf die Löslichkeit von Schwermetallen. Mitteilgn. Dtsch. Bodenkundl. Gesellsch. 27, 181-192.

Herms, U. und Brümmer, G. (1980): Einfluss der Bodenreaktion auf Löslichkeit und tolerierbare Gesamtgehalte an Nickel, Kupfer, Zink, Cadmium und Blei in Böden und kompostierten Siedlungsfällen. Landwirtsch. Forsch. 33, 404-423.

Herms, U. und Brümmer, G. (1984): Einflussgrößen der Schwermetalllöslichkeit und -bindung in Böden. Z. Pflanzenernähr. Bodenk. 147, 400-424.

Hooda, P. S., McNulty, D., Alloway, B. J., (1997): Plant Availability of Heavy Metals in Soils Previously Amended with Heavy Applications of Sewage Sludge. J Sci Food Agric, 73, 446-454. 
Inouhe M, Ninomiya S, Tohoyama H, Joho M, Murayama T (1994): Different characteristics of roots in the cadmium-tolerance and $\mathrm{Cd}$ binding complex formation between mono- and dicotyledonous plants. J Plant Res 107:201207.

Jackson, A. P. and Alloway, B. J. (1991): The bioavailability of cadmium to lettuce and cabbage in soils previously treated with sewage sludge. Plant Soil 132: 179-186.

Jones, D. L. (1998): Organic acids in the rhizosphere - a critical review. Plant and Soil 205: 25-44.

Jungk, A., Claassen, N., (1997): Ion Diffusion in the Soil-Root System. Adv. Agron. 61, 53-110.

Jungk, A.O., (2002): Dynamics of nutrient movement at the 1189 soil-root interface. In: Waisel, Y., Eshel, A., Kafkafi, U. (Eds.), 1190 Plant Roots, The Hidden Half. Marcel Dekker, Inc., New York, 1191 pp. 587-616, Chapter 35.

Keller, H., (2000): Einfluss wurzelbürtiger organischer Säure auf das $\mathrm{Cu}-$-, $\mathrm{Zn} \mathrm{-,} \mathrm{und}$ $\mathrm{Cd}$ - Aneignungsvermögen von Spinatgenotypen. Dissertation, Kaiserslautern.

Keltjens W.G. and van Beusichem, M.L. (1998): Phytochelatins as biomarker for heavy metal stress in maize (Zea mays L.) and wheat (Triticum aestivum L.): combined effects of copper and cadmium, Plant Soil 203, pp. 119-126.

Kennedy, C. D. and Gonsalves F. A. N. (1987): The Action of Divalent Zinc, Cadmium, Mercury, Copper and Lead on the Trans-Root Potential and $\mathrm{H}^{+}$, Efflux of Excised Roots. J. Exp. Bot. 38 (5): 800-817. doi: 10.1093/jxb/38.5.800.

Keppler, J. (1999): Modellversuche und Geländeuntersuchungen zur Kinetik der Schwermetall-Festlegung sowie zur Löslichkeit, Mobilisierung und Verlagerung von Schwermetallen in belasteten Böden. Inaugural-Dissertation, Bonn.

Kloke von A. und Schenke, H. - D. (1979): Der Einfluss von Cadmium im Boden auf den Ertrag verschiedener Pflanzenarten und deren Cadmiumgehalt. Z. Pflanzenernährt. Bodenkd. 142, 131-136.

Kuo, S. and Baker, A.S., (1980): Sorption of copper, zinc, and cadmium by some acid soils. Soil Sci. Soc. Am. J. 44, pp. 969-974.

Li, Y.-M, Chaney, R.L., Schneiter, A.A. and Miller, J.F. (1995): Genotypic variation in kernel cadmium concentration in sunflower germplasm under varying soil conditions. Crop Sci. 35, pp. 137-141. 
Lindsay, W. I. (1979): Chemical Equilibria in Soils. John Wiley \& Sons, New York. pp 316-326.

Lindsay, W.L. und Norvell, W.A. (1978): Development of a DTPA soil test for zinc, iron, manganese, and copper. Soil Sci. Soc. Am. J. 42, 421-42.

Ma, Y.B. and Uren, N.C. (1998): Transformations of heavy metals added to soilapplication of a new sequential extraction procedure. Geoderma 84 157-168.

Mahler, R. J., Bingham, F. T., Pace, A. L., and Ryan J. A. (1982): Cadmium-Enriched Sewage Sludge Application to Acid and Calcareous Soils: Effect on Soil and Nutrition of Lettuce, Corn, Tomato, and Swiss Chard. J. Environ. Qual. 11, 694700.

Marschner, H. (1995): Mineral Nutrition of Higher Plants. Academic Press, London. Marschner, H. and V. Roemheld, 1996. Root Induced Changes in the Availability of Micronutrients in the Rhizosphere. In: Plant Roots the Hidden Half, Waisel, Y., A. Eshel and U. Kafkafi (Eds.). Marcel Dekker Inc., New York, Basel, Hong Kong, pp: 557-579.

Mench, M. and Martin, E., (1991): Mobilization of cadmium and other metals from two soils by root exudates of Zea mays L., Nicotiana tabacum L. and Nicotiana ristica L. Plant ans Soil 132, 187-196.

Meyer, D. (1993): Effizienz von Kulturpflanzen bei der Nutzung des nichtaustauschbaren Kaliums von Böden. Dissertation, Univ. Göttingen.

Morel, J.L., Mench, M. and Guckert, A. (1986): Measurement of $\mathrm{Pb}^{2+}, \mathrm{Cu}^{2+}$ and $\mathrm{Cd}^{2+}$ binding with mucilage exudates from maize (Zea mays L.) roots Biol Fertil Soils 2:29- 34.

Nolan, A. L., McLaughlin, M. J., and Mason, S. D. 2003. Chemical speciation of Zn, $\mathrm{Cd}, \mathrm{Cu}$, and $\mathrm{Pb}$ in pore waters of agricultural and contaminated soils using Donnan dialysis, Environ. Sci. Technol., 37:90-98.

Nye, P H., Marriot, F H. C. (1969): A theoretical study of the distribution of substances around roots resulting from simultaneous diffusion and mass flow. Plant and Soil 30, 459-472.

Nye, P. H. and Tinker, P. B. (1977): Solute Movement in the Soil-Root System. Nye, P.H., (1973): The Relation Between the Radius of a Root and its Nutrientabsorbing Power $[\alpha]$. J. Exp. Bot. 24 (5): 783-786. doi: 10.1093/jxb/24.5.783. 
Padeken, K., (1998): Schwermetallaufnahme verschiedener Pflanzenarten unter besonderer Berücksichtigung der $\mathrm{N}$ - und P-Ernährung. Landbauforschung Völkenrode, Sonderheft 182, Dissertation, Göttingen.

Parsons, R. (1959): Handbook of Electrochemical Constants. Academic Press, New York.

Ratuzny, T., Gong, Z., Wilke, B.-M. (2009): Total concentrations and speciation of heavy metals in soils of the Shenyang Zhangshi Irrigation Area, China. Environ Monit Assess 156, 171-180.

Sadana, S. U., Sharma, P., Castañeda Ortiz, N., Samal, D. and Claassen, N. (2005): Manganese uptake and $\mathrm{Mn}$ efficiency of wheat cultivars are related to $\mathrm{Mn}$ uptake kinetics and root growth. J. Plant Nutr. Soil Sci. 168, 581-589.

Salt, D. E., Prince, R. C., Pickering, I. J. and Raskin, I., (1995): Mechanisms of cadmium mobility and accumulation in Indian mustard. Plant Physiol. 109: 1427-1433.

Sandalio, L. M., Dalurzo, H. C., Gomez, M., Romero-Puertas, M. C., and del Rio, L. A. (2001) Cadmium-induced changes in the growth and oxidative metabolism of pea plants. Journal of Experimental Botany 52, 2115-2126. doi: 10.1093/jexbot/52.364.2115.

Sarkar, B (2002): Heavy metals in the environment. Marcel Dekker AG. New York. Sayyari Zahan, M. H. (2008): Manganese Efficiency and Manganese Uptake Kinetics of Different Crop Species. PhD thesis. University Goettingen, Germany.

Scheffer / Schachtschabel (2002): Lehrbuch der Bodenkunde, 15 Aufl. Spektrum, Heidelberg, Berlin.

Scheffer / Schachtschabel (2010): Lehrbuch der Bodenkunde, 16 Aufl. Spektrum, Heidelberg, Berlin.

Seiffert, S., Kaselowsky, J., Jungk, A. and Claassen, N. (1995): Observed and Calculated Potassium Uptake by Maize as Affected by Soil Water Content and Bulk Density. Agron. J. 87, (6), 1070-1077.

Senden, M.H.M.N., van der Meer, A.J.G.M., Verburg, T.G. and Wolterbeek, H.Th., (1995): Citric acid in tomato plant roots and its effect on cadmium uptake and distribution. Plant and Soil 171, 333-339. 
Serrano, S., Garridoa, F., Campbellb, C. G. and Garcia-Gonzaleza, M.T. (2005): Competitive sorption of cadmium and lead in acid soils of Central Spain. Geoderma 124, 91-104.

Sikka. R. V. Nayyar and Sidhu., S.S. (2009). Monitoring of Cd pollution in soils and plants irrigated with untreated sewage water in some industrialized cities of Punjab, India. Environ. Monit. Assess., 154: 53-64.

Simmons R W., Pongsakul P., Chaney R. L, Saiyasitpanich D., Klinphoklap S. \& Nobuntou W. (2003): The relative exclusion of zinc and iron from rice grain in relation to rice grain cadmium as compared to soybean: Implications for human health. Plant and Soil 257: 163-170.

Singh, B.R. \& Myhr, K. (1997): Cadmium leaching from cadmium-enriched fertiliser in field lysimeters. In: Proceedings of 4th International Conference on the Biogeochemistry of Trace Elements (eds I.K.Iskander, S.E.Hardy, A.C.Chang \& G.M.Pierzynski), pp. 105-106. International Society of Trace Element Biogeochemistry, Berkeley, CA.

Somashekaraiah, B., K. Padmaja, A. Prasad, 1992. Phytotoxicity of cadmium ions on germinating seedlings of mung bean (Phaseolus mungo): involvement of lipid peroxides in chlorophyll degradation. Physiol. Plant., 85, 85-89.

Sponito, G. (1989): The Chemistry of Soils. Oxford university press, New York.

Sposito, G., Holtzclaw, K. M. and Le Vesque-Madore, C. S. (1981): Sodium-Calcium and Sodium-Magnesium Exchange on Wyoming Bentonite in Perchlorate and Chloride Background Ionic Media. Soil Sci. Soc. Am. J. 45, 465-468.

Steingrobe, B., (1992): Beschreibung der Nitrataufnahmerate mit Hilfe eines Simulatuionsmodells am Beispiel von Kopfsalat (Lactuca sativa L.). Dissertation Univ. Hannover, Verlag Ulrich E. Grauer, Wendlingen.

Stobart, A.K., Griffiths, W.T., Ameen-Bukhari, I., Sherwood, R.P. (1985): The effect of $\mathrm{Cd} 2 \S$ on the biosynthesis of chlorophyll in leaves of barley. Physiol. Plant. 63: 293-298.

Stritsis, C. (2005): Cd-Aufnahme aus dem Boden verschiedener Pflanzenarten in Beziehung zum Wurzelwachstum und zur Aufnahmekinetik. Masterarbeit. Universität Göttingen, Deutschland.

Swift RS, McLaren RG (1991): Micronutrient adsorption by soils and soil colloids. In Interactions at the Soil Colloid-Soil Solution Interface. Ed. GH Bolt, MF De 
Boodt, MHB Hayes, MB McBride MB, pp. 257-292, Kluwer Academic Publishers, Dordrecht.

Tennant, D. (1975): A test of a modified line intersect method of estimating root length. J. Ecol. 63, 995-1001.

Tessier, A., Campell, P. G. and Bisson, M. (1979): Sequential Extraction Procedure for the Speciation of Particulate trace metals. Anal. Chem. 51, 844-85.

Tiller, K.G., Gerth J. und Brümmer G. (1984a): The sorption of Cd, Zn and Ni by soil clay fractions: procedures for partition of bound forms and their interpretation. Geoderma 34, 1-16.

Tiller, K.G., Gerth J. und Brümmer G. (1984b): The relative affinities of Cd, Zn and $\mathrm{Ni}$ for different soil clay fractions and goethite. Geoderma 34, 17-35.

Trehan, S.P., Claassen, N., 2000: Potassium uptake efficiency of potato and wheat in relation to growth in flowing solution culture. Potato Research 43, 9-18.

Trehan, S.P., Claassen, N., 2004: Adaption of potato cultivars to low potassium supply in flowing solution culture. Adv. Hort. Sci., 18(4), 188-192.

Uraguchi S, Watanabe I, Yoshitomi A, Kiyono M, Kuno K. (2006): Characteristics of cadmium accumulation and tolerance in novel Cd-accumulating crops, Avena strigosa and Crotalaria juncea. Journal of Experimental Botany 57, 29552965.

Ure, A. M., Quevauviller, Ph., Muntau, H. and Griepink, B. (1993): Speciation of Heavy Metals in Soils and Sediments. An Account of the Improvement and Harmonization of Extraction Techniques Undertaken Under the Auspices of the BCR of the Commission of the European Communities. International Journal of Environmental Analytical Chemistry, 51: 1, 135-151.

Van Assche, F. and Clijsters, H. (1990): Effects of metals on enzyme activity in plants. Plant, Cell \& Environment. Volume 13, Issue 3, pages 195-206. DOI:10.1111/j.1365-3040.1990.tb01304.

van den Berg, J. D., Vermist, N. D., Carlyle, L., Holčapek, M. and Boon, J. J. (2004): Effects of traditional processing methods of linseed oil on the composition of its triacylglycerols. Journal of Separation Science, 27:181-199. doi:10.1002/jssc.200301610 
Vassilev, A., Lidon, F. C., Matos, M. do C., Ramalho, J. C., Yordanov, I., (2002): Photosynthetic perfomance and content of some nutrients in cadmium- and copper-treated Barley plants. J. Plant Nutr. Vol. 25 , Issue 11, 2343- 2360.

Wang, K. R. (2002): Tolerance of Cultivated Plants to Cadmium and their Utilization in Polluted Farmland Soils. Acta Biotechnol. 22, 1-2, 189-198.

Weigel, H. J. and Jäger, H. J. (1980): Different Effects of Cadmium in vitro and in vivo on Enzyme Activities in Bean Plants (Phaseolus vulgaris L. c. v. Sankt Andreas) Z. Pflanzenphysiol. 97, 103-113.

Williams, R. F. (1948): The effect of phosphorus supply on the rates of intake of phosphorus and nitrogen upon certain aspects of phosphorus metabolism in gramineous plants. Aust. J. Sci. Res. 1, 333-361.

Wójcik, M., Tukiendorf, A. (2005): Cadmium uptake, localization and detoxification in Zea mays. Biol. Plant. 49: 237-245.

Yang, X. E,. Long, X. X., Ye, H. B., He, Z. L., Calvert, D. V \&. Stoffella, P. J. (2004): Cadmium tolerance and hyperaccumulation in a new Zn-hyperaccumulating plant species (Sedum alfredii Hance). Plant and Soil 259, 181-189.

Yang, X. E., Baligar, V. C., Martens, D. C. and Clark, R. B., (1996): Cadmium effects on influx and transport of mineral nutrients in plant species. J. Plant Nutr. 19(3\&4), 643-656.

Zeien, $\quad H$ (1995): Chemische Extraktionen zur Bestimmung von Schwermetallbindungsformen in Böden. Inaugural-Dissertation, Bonn.

Zeien, H. und Brümmer, G.W. (1989): Chemische Extraktionen zur Bestimmung von Schwermetallbindungsformen in Böden. Mitteilung. Dtsch. Bodenkundl. Gesellsch., 59/1, 1989, 505-510.

Zeien, H. und Brümmer, G.W. (1991): Ermittlung der Mobilität und Bindungsformen von Schwermetallen in Böden mittels sequentieller Extraktionen. Mitteilgn. Dtsch. Bodenkundl. Gesellsch. 439-442. 


\section{APPENDIX}

Table 8-1 The sequential extraction scheme for Cd fractionation after Zeien and Brümmer (1989)

\begin{tabular}{|c|c|c|}
\hline Fraction & Extractant & Extraction \\
\hline I. & $1 \mathrm{M} \mathrm{NH}_{4} \mathrm{NO}_{3}$ (unbuffered) & 24 h shaking \\
\hline \multirow[t]{2}{*}{ II. } & $1^{\text {st }}$ step $1 \mathrm{M} \mathrm{NH}_{4} \mathrm{OAc}(\mathrm{pH} 6.0)$ & $1^{\text {st }}$ step $24 \mathrm{~h}$ shaking \\
\hline & $2^{\text {nd }}$ step $1 \mathrm{M} \mathrm{NH}_{4} \mathrm{NO}_{3}$ (unbuffered) & $2^{\text {nd }}$ step $10 \mathrm{~min}$ \\
\hline \multirow[t]{2}{*}{ III. } & $1^{\text {st }}$ step $0.1 \mathrm{M} \mathrm{NH}_{2} \mathrm{OH}-\mathrm{HC} 1+1 \mathrm{M} \mathrm{NH}_{4} \mathrm{OAc}(\mathrm{pH} 6.0)$ & $1^{\text {st }}$ step 30 min shaking \\
\hline & $2^{\text {nd }}$ step (2 times) $1 \mathrm{M} \mathrm{NH}_{4} \mathrm{OAc}(\mathrm{pH} 6.0)$ & $2^{\text {nd }}$ step $10 \min$ ( 2 times) \\
\hline \multirow[t]{2}{*}{ IV. } & $1^{\text {st }}$ step $0.025 \mathrm{M} \mathrm{NH}_{4}-\mathrm{EDTA}+1 \mathrm{M} \mathrm{NH}_{4} \mathrm{OAc}(\mathrm{pH} 4.6)$ & $1^{\text {st }}$ step 90 min shaking \\
\hline & $2^{\text {nd }}$ step $1 \mathrm{M} \mathrm{NH}_{4} \mathrm{OAc}(\mathrm{pH} 4.6)$ & $2^{\text {nd }}$ step $10 \mathrm{~min}$ \\
\hline \multirow[t]{3}{*}{ V. } & $1^{\text {st }}$ step $0.2 \mathrm{M} \mathrm{NH}_{4}$-oxalate-buffer $(\mathrm{pH} 3.25)$ & $1^{\text {st }}$ step $4 \mathrm{~h}$ shaking (indarkness) \\
\hline & $2^{\text {nd }}$ step $0.2 \mathrm{M} \mathrm{NH}_{4}$-oxalate-buffer $(\mathrm{pH} 3.25)$ & $2^{\text {nd }}$ step 10 min shaking \\
\hline & & (indarkness) \\
\hline \multirow[t]{3}{*}{ VI. } & $1^{\text {st }}$ step $0.1 \mathrm{M}$ ascorbic acid $+0.2 \mathrm{M}$ oxalate puffer $(\mathrm{pH}$ & $1^{\text {st }}$ step $1 \mathrm{~h}$ boiling at $96^{\circ} \mathrm{C}$ \\
\hline & $3.25)$ & $2^{\text {nd }}$ step 10 min shaking \\
\hline & $2^{\text {nd }}$ step $0.2 \mathrm{M} \mathrm{NH}_{4}$-oxalate-buffer ( $\left.\mathrm{pH} 3.25\right)$ & (indarkness) \\
\hline \multirow[t]{3}{*}{ VII. } & conc. $\mathrm{HCl} /$ conc. $\mathrm{HNO}_{3}$ & $45 \min$ at $70^{\circ} \mathrm{C}$ \\
\hline & & $30 \mathrm{~min}$ at $110^{\circ} \mathrm{C}$ \\
\hline & & $180 \mathrm{~min}$ at $120^{\circ} \mathrm{C}$ \\
\hline Total Cd & $\mathrm{HNO}_{3}$ & $12 \mathrm{~h}$ at $180^{\circ} \mathrm{C}$ \\
\hline
\end{tabular}


Table 8-2 Partitioning of $\mathrm{Cd}$ in sandy soil (pHCaCl2 4.5, 2.8\%, $5 \%$ clay) among the seven fractions of

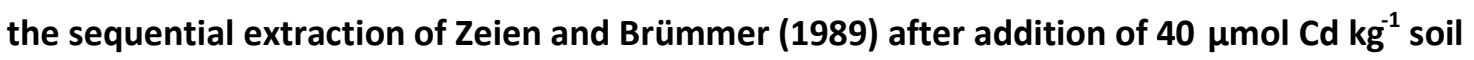

\begin{tabular}{|c|c|c|c|c|c|}
\hline Fraction & Control & Maize & Sunflower & Flax & Spinach \\
\hline & \multicolumn{5}{|c|}{$\mu \mathrm{mol} \mathrm{Cd} \mathrm{kg}^{-1}$} \\
\hline I. & 14.3 & 12.8 & 11.7 & 11.8 & 11.7 \\
\hline II. & 13.1 & 16.5 & 13.6 & 11.4 & 17.2 \\
\hline III. & 9.6 & 9.0 & 5.9 & 9.6 & 7.1 \\
\hline IV. & 4.3 & 6.1 & 4.3 & 6.0 & 4.8 \\
\hline V. & 1.0 & 1.3 & 1.2 & 1.2 & 1.1 \\
\hline VI. & 0.6 & 0.4 & 0.3 & 0.5 & 0.4 \\
\hline VII. & 0.2 & 0.1 & 0.1 & 0.1 & 0.2 \\
\hline SUM & 43.0 & 46.2 & 37.1 & 40.5 & 42.4 \\
\hline $\mathrm{Cd}_{\mathrm{t}}$-Teflon* & 50.6 & 49.7 & 39.8 & 47.6 & 44.5 \\
\hline Retrieval (\%) & 85 & 93 & 93 & 85 & 95 \\
\hline
\end{tabular}

*Determination of the total $\mathrm{Cd}\left(\mathrm{Cd}_{\mathrm{t}}\right)$ content was performed independently on another soil sample $(0.2 \mathrm{~g}$ dry wt) in teflon box under high pressure for $12 \mathrm{~h}$ at $180^{\circ} \mathrm{C}$.

Table 8-3 Soil solution Cd concentrations at first and second harvest obtained from modified displacement method according to Adams (1974)

\begin{tabular}{lccc}
\hline Plant & & \multicolumn{2}{c}{$\mathbf{C}_{\mathrm{Li}}$} \\
& & $\mathbf{1 0}^{-9} \mathbf{m o l ~ c m}^{-3}$ & \\
& $1^{\text {st }}$ Harvest & $14 \mu \mathrm{mol} \mathrm{Cd} \mathrm{kg}^{-1}$ & \\
\cline { 2 - 4 } Maize & & 0.2 & 0.22 \\
Sunflower & 0.3 & 0.3 & 0.38 \\
Flax & 0.5 & 1.5 & 1.19 \\
Spinach & 0.9 & 0.6 & 0.48 \\
\cline { 2 - 4 } & 0.3 & $40 \mu \mathrm{mol} \mathrm{Cd} \mathrm{kg}{ }^{-1}$ & 0.74 \\
Maize & & 0.4 & 1.80 \\
Sunflower & 1.0 & 1.4 & 4.59 \\
Flax & 2.2 & 5.8 & 3.07 \\
Spinach & 3.3 & 4.3 & \\
\hline
\end{tabular}




\section{ACNOWLEDGEMENTS}

After much round table debate and controversy spanning a period of over 4 years, it's time to get out feelings and gratitude to light. I am certainly grateful to many people who supported directly and indirectly in a number of ways, enabling me to complete my doctoral dissertation. To accomplish a doctoral dissertation, a doctoral thesis supervisor, good technical staff, naturally the PhD student himself and a project, should all come together in the right place and at the right time.

I would like to thank my supervisor, Prof. Dr. Norbert Claassen, for consenting to the project, his uncomplaining introduction into the topic and for the comprehensive and committed support I received. Moreover, his ever-ready responsiveness, his sometimes critical and often constructive suggestions, his steady willingness to discuss the experiments from conduct to the statistically evaluation were a valuable assistance in the creation of this scientific work. I also want to thank him why he selected a foreign PhD student and gave him the opportunity to become acquainted with German society better.

I would also like to thank Prof. Dr. Norbert Lamersdorf, for his kind willingness to take on the co-supervisor, and Prof. Dr. Stefan von Cramon - Taubadel for agreeing to be a member of the examination board, helping in this way to combine agricultural policy with agricultural chemistry.

I would like to express my appreciation to Dr. Bernd Steingrobe and thank him because he was always willing to help and answer my questions. I also wish to 
thank Prof. Wilhelm Römer and Dr. Joachim Schulze for their assistance, encouragement and moral support during my studies and with the project.

The results of a good PhD thesis are based heavily on a well-trained technical staff. Therefore, I'm thankful to Mrs S. Koch for interest, advice, valuable introduction to and assistance in the analytical process. For accuracy in the measurement of $\mathrm{Cd}$ with AAS, which led to impressive results, I would like to thank Mr. M. Hanke. I also thank Mrs Eichenberg, Mrs. Niebuhr, Mrs. Bettina Egger, Mrs. Gunda Jansen, Mr. Reinhard Hilmer, and Mr. Jürgen Kobbe, who helped me in carrying out the experiments and analysis. I also thank K. C. Luers and M. Noltkämper for help with German bureaucracy. I thank too, all employees of the Institute of Agricultural Chemistry for their support, cooperation and the good working atmosphere.

I thank my colleague, Dr. N. Castaneda-Ortiz, Dr. P. Fischinger, Dr. Hassan-Sayyari Zahan, Dr. RA Cabeza Perez, Dr. S. Sulieman, for their shared cooperation during this $\mathrm{PhD}$ thesis period.

My sister A. Stritsi M.Sc.Chem., I would like to thank for their valuable assistance in chemical questions.

My parents, family members and friends I would like to thank for their patience and advice.

The German Research Foundation (DFG), I thank for the financial support of this research project. 


\title{
10 CURriculum VItAE
}

\author{
Name Christos Stritsis \\ Sex Male \\ Date of birth $\quad$ 19.11.1969 \\ Place of birth Goumenissa, D. Paionias, P. Central Makedonia - Grecce \\ Nationality Greek \\ Work Experiences \\ $2007-2011$ \\ Research assistant in project "Differential shoot $\mathbf{C d}$ accumulation in \\ crops" at the Department of Crop Sciences, Institute of Agricultural \\ Chemistry, Section of Plant Nutrition and Crop Physiology, University of \\ Göttingen \\ 2005-2007 Research/Teaching assistant at the Department of Crop Sciences, Institute \\ of Agricultural Chemistry, Section of Plant Nutrition and Crop Physiology, \\ University of Göttingen.
}

\author{
Education \\ $2007-2010$ \\ Ph.D. Department of Crop Sciences, Section of Plant Nutrition and Crop \\ Physiology, University of Göttingen \\ $2003-2005$ M. Sc. Department of Crop Sciences, Section of Plant Nutrition and Crop \\ Physiology, University of Göttingen \\ $1999-2003 \quad$ B. Sc. Department of Crop Sciences, Section of Agricultural Entomology \\ University of Göttingen \\ $1981-1987 \quad$ Gymnasium und Lyzeum in Griechenland
}

International Seminar

26-28.9. 2006 Symposium "Plant Nutrition meets Plant Breeding" in Hohenheim, Deutschland.

Topic: Differential cadmium accumulation in crops as related to their uptake kinetics and rhizosphere effects.

$8-21.9 .2007$

119. VDLUFA-Congress in Göttingen, Deutschland

Topic: Cadmium accumulation of maize, sunflower, spinach and flax as related to their uptake kinetics and rhizosphere effects. 